\title{
Probleme Dayalı Öğrenmenin Fen Bilimleri Öğretmen Adaylarının Pedagojik Alan Bilgisi Gelişimlerine Etkisi"
}

\author{
Tufan İnaltekin $^{* * 1}$ ve Fatma Şahin ${ }^{2}$
}

$\ddot{O} z$

Bu araştırmanın amacı, probleme dayalı öğrenme (PDÖ) yaklaşımının fen bilimleri öğretmen adaylarının pedagojik alan bilgisi (PAB) gelişimlerine etkisini incelemektir. Araştırmada, öğretmen adaylarının ögretim иуити, program, öğrenciyi anlama, öğretim stratejileri ve temsilleri ile değerlendirme bilgisi bağlamında PAB gelişimleri incelenmiştir. Araştırmada öntest - sontest kontrol gruplu deneysel araştırma modeli kullanılmıştır. Bu araştırma, İstanbul ilindeki bir devlet üniversitesinin fen bilimleri öğretmenliği programı üçüncü sınıfinda öğrenim gören 30’u deney, 30’u kontrol grubu olmak üzere toplam 60 ögretmen adayıyla yürütülmüştür. Deney grubunda öğretmen adayları PAB yapılarını PDÖ ile kontrol grubundakiler ise öğretmen adayı eğitimcisinin ders sunumları ve öğrenci çalışmalarıyla biçimlendirmişlerdir. Veriler Fen Öğretim Uyumu Testi ve Öğretim Temsil Formu kullanılarak toplanmıştır. Verilerin analizinde betimsel analiz tekniği kullanılmıştır. Araştırmanın bulguları, PDÖ yoluyla PAB yapılanmasını gerçekleştiren deney grubu ögretmen adaylarının, kontrol grubundakilere kıyasla PAB yapılarını daha fazla geliştirdiklerini ortaya koymuştur. Araştırmadan elde edilen bu sonuç, lisans dönemi fen bilimleri öğretmen adayı hazırlığında eğitimcilerin, PDÖ uygulamaları yoluyla alan ve pedagoji derslerini harmanlamalarının, öğretmen adaylarının mesleki gelişimlerine önemli katkılar sağlayacağını göstermektedir.

Anahtar Sözcükler

Probleme dayalı öğrenme

Pedagojik alan bilgisi Fen bilimleri öğretmen

adayı

Makale Hakkında

Gönderim Tarihi

24 Şubat 2018

Kabul Tarihi

12 Ekim 2018

Makale Türü

Araştırma Makalesi

DOI: 10.12984/egeefd.398279

\section{The Effects of Problem Based Learning on Development of Preservice Science Teachers' Pedagogical Content Knowledge*}

\begin{abstract}
The aim of this study is to examine the effect of problem based learning (PBL) on progress of preservice science teachers in pedagogical content knowledge (PCK). Progress of preservice teachers in PCK was examined in the context of orientations toward teaching, curriculum, student understanding, instructional strategies and representations and knowledge of assessment. The research was conducted with 60 preservice teachers (experimental group, $n=30$ and control group, $n=30$ ) who were in the third year at the department of science teaching at a state university in İstanbul. The experimental group formalised the construction of PCK through practises of PBL whereas the ones in the control group did it through practises of lecturer. The data was collected via Test of Orientation in Science Teaching and Form of Teaching Representation. The data was analyzed via techniques of descriptive and content analysis. Results indicated that the preservice teachers who carried out the construction of PCK through PBL had made more progress than the ones in the control group. Thus, the efficient blending of major area courses in undergraduate period would make a great contribution to vocational development of preservice science teachers.
\end{abstract}

Keywords

Problem based learning Pedagogical content knowledge Preservice science teacher

Article Info

Received

February 24, 2018 Accepted

October 12, 2018

Article Type

Research Paper

Attf: İnaltekin, T. ve Şahin, F. (2019). Probleme dayalı öğrenmenin fen Bilimleri öğretmen adaylarının pedagojik alan bilgisi gelişimlerine etkisi. Ege Eğitim Dergisi, 20(1), 78-112 doi: 10.12984/egeefd.398279

\footnotetext{
** Bu makele Tufan İnaltekin'in doktora tezinden üretilmiştir [This article is derived from Tufan İnaltekin’s PhD dissertation].

Sorumlu Yazar/Corresponding Author

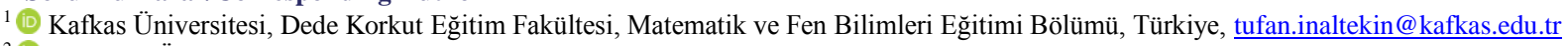

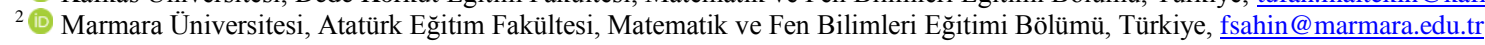




\section{Extended Abstract}

\section{Introduction}

Nowadays, the academics who are thinking and searching upon developing science teaching emphasize the importance of teachers' experiences obtained during university education in providing significant learning opportunities for their students in the future. Therefore, undergraduate applications which will give an opportunity to find out how our teachers will associate subject area with their pedagogical knowledge conformably need to be defined. Alongside of assessment of science teachers at secondary school in certain topics in relation to constructions of Pedagogical Content Knowledge (PCK), it is highly important to submit samples of development model through which they will interrogate these constructions. In recent years, there is a broad tendency to query and research-based learning processes in order to develop an understanding of CK and PCK of preservice science teachers as a step of reformative applications in science education. Problem Based Learning (PBL), one of these processes provides great opportunities in progress of preservice science teachers' knowledge structures based upon social interaction. In this context, the examination of whether a pedagogy of PBL is effective on the progress of construction of PCK which preservive science teachers obtained in undergraduate education or not has constituted the primary aim of the research. Within this framework, it was firstly aimed the effect of practises of PBL to be tested experimentally on PCK progress of preservive science teachers by creating two dissimilar learning groups.

\section{Method}

This research is an experimental study which examines what effect two different learning programs applied on preservive science teachers have on their PCK progress. In this research, random experimental design with a control group, where pretest and posttest were administered was used. In this context, the representative sample was composed of 60 preservive teachers who were in their third year at the department of science teaching at a state university. For the experimental application of this research, two different undergraduate classes were selected. Of those classes, the class of Human Anatomy and Physiology was selected for content knowledge and class of Special Teaching Methods was selected for content training. The data of the research was collected from preservive teachers in both groups via Test of Orientation in Science Teaching and Form of Teaching Representation before and after the application. Quantitative data of preservive science teachers in both experimental and control group was analyzed separately in respect of six different contents. Quantitative data regarding each subject content was calculated in both of the groups as a mean value in the last analysis. Also, qualitative data collected from both of the groups via Forms of Teaching Representation before and after application was transformed into quantitative data with the help of some rubric including criteria of PCK and then scores regarding subject contents that each group had were calculated.

\section{Findings}

Based on the findings, it was determined that preservive teachers in the experimental group had the highest preference of orientation in science teaching in the dimension of direct information by an average of $43 \%$ and the lowest preference of orientation in science teaching in the dimension of learning by discovery by an average of $10 \%$ in all the content topics before the application. However, it was determined that preservive science teachers in the control group had the highest preference of orientation in science teaching in the dimension of direct information by an average of $46 \%$ and the lowest preference of orientation in science teaching in the dimension of learning by discovery by an average of $11 \%$ before the application. It was determined that preservive teachers in the experimental group had the highest preference of orientation in science teaching in the dimension of inquiry in company with guidance by an average of $31 \%$ and the lowest preference of orientation in science teaching in the dimension of direct information by an average of $12 \%$ after the application. However, it was seen that preservive teachers in the control group had the highest preference of orientation in science teaching in the dimension of direct interaction by an average of $38 \%$ and the lowest preference of orientation in science teaching in the dimension of learning by discovery by an average of $17 \%$ after the application. According to the findings obtained from the form of content representation before the application, it was determined that preservive teachers of both groups were similar to each other with regards to levels of producing an applicable idea. Nevertheless, it was determined that the preservive teachers in the experimental group had made more progress than the ones in the control group with regards to levels of producing an applicable idea after the application. 


\section{Discussion and Conclusion}

It was determined that the preservive teachers in the experimental and control group had opined mainly before the application that students should have learnt the knowledge concerning science availably. However, it was revealed that orientation in science teaching belonging to the preservive teachers in the experimental group had tended towards a sense of teaching in science in the direction of inquiry and discovery-based learning after the application to a larger extent compared to the ones in the control group. This states that practises of PBL have influenced more positively the orientation in science teaching belonging to the preservive teachers in terms of reform-based learning. Also, it was concluded that PBL had been more effective than normal curriculum in improving the sense of PCK of preservive science teachers who got more score rise in scores of form of content representation after the application. These results show that it is possible for preservive science teachers to have a more specific sense of science teaching on the condition that they are given an opportunity of interrogating and constructing the knowledge structures they have through various teaching constitutions. Besides, being able to going through the most powerful change in preservive science teachers' senses concerning instruction may merely be provided as the result of experiences that will be gained in effective applications. 


\section{Giriş}

21. Yüzyılda toplumlar gelecekleri için en temel eğitim politikasını, bilgiyi daha üretken ve sistematik bir şekilde kullanan bireylerin yetiştirilmesi üzerine kurmuşlardır. Dünyada birçok ülke, bu düşünceye yön verecek ve çağın gereksinimlerini karşılayacak bireyleri yetiştirmek için sürekli eğitim reformları ortaya koymaktadırlar. Bilimsel bilgiyi üretme ve kullanma şu anda günümüz toplumlarında, ekonomik gücün merkezindedir. Öğrencilerin bilimsel bilgiye ilişkin düşünceleri, evde, okulda ve çevresindeki deneyimler ve sosyal etkileşimler sonucunda biçimlenmektedir (Cowie, Jones ve Otrelcass, 2011). Bu bağlamda bilimsel bilgiyi yapılandırmaya ilişkin firsatların, öğrenenlerin üst düzey düşünme yeteneğini destekleyecek nitelikte süreçleri içermesi gerekmektedir (Campbell, Longhurst, Wang, Hsu ve Coster, 2015; Donnelly ve Hume, 2015; Fortus ve Vedder-Weiss 2014; McNaught, Lam ve Cheng, 2012; Nilsson, 2014).

Eğitimde nitelik farklı boyutlar üzerinden tartışılması gereken çok yönlü bir konudur. Fiziksel koşullar, öğretmenler, müfredat, ölçme-değerlendirme gibi unsurlar bazen tek bazen de toplu bir biçimde verilen eğitimin niteliğini şekillendirebilmektedir. Bu boyutlar üzerinden değerlendirildiğinde, nitelikli bir eğitimi belirleyen en temel dinamiklerden birisi belki de öğretmenlerdir. Tüm eğitimsel şartların gayet iyi, öğrencilerin ise öğrenmeye oldukça istekli olduğu bir eğitim sisteminde bile bu imkânları değerlendirecek bilgiden yoksun öğretmenlerle nitelikli bir eğitimin ortaya çıkması beklenemez (Özoğlu, 2010). Öğretmenlerin niteliği konusunda, öğrenme ortamının hazırlanmasından, öğrencilere anlamlı bilgiyi kazandırabilmeye, uygun yöntem ve tekniklerin seçiminden, öğrencilerin nasıl değerlendirildiğine kadar birçok unsur dikkate alınmaktadır (Timur, 2011). Bunun yanında son yıllarda öğretmen niteliğinin, öğrenci bağlamında önemi, çeşitli çalışmalarla tartışmaya yer bırakmayacak bir şekilde ifade edilmiştir. Avrupa Parlamentosunun 2008 yılında öğretmen niteliğinin geliştirilmesi için aldığı bir kararda öğretmen eğitimi ve niteliğinin önemi şu şekilde vurgulanmaktadır: "Öğretmen eğitiminin niteliği, eğitim-öğretim uygulamalarında kendini gösterir ve çocukların yalnızca bilgisinin gelişmesinde değil, özellikle eğitimlerinin ilk yıllarında kişiliklerinin biçimlenmesi üzerinde de doğrudan bir etkiye sahiptir." (Türk Eğitim Derneği [TED], 2009, s. 2).

Son yirmi yıldan bu yana bilginin öğrenen tarafından yapılandırılması, fen eğitimini de etkilemiş ve baskın tartışma alanı olmuştur. Bu durum bilişsel öğrenme süreçlerini içeren yoğun tartışmalar etrafında şekillenmiştir (Yen, Tuan ve Liao, 2011). Fen eğitiminin niteliğini geliştirmeye yönelik uluslararası çabalar, öğrenenlerinin fen konularıyla aktif bir şekilde meşgul olmalarına, bilimsel kavramlar arasında bağlantılar kurmalarına, problemleri çözmek için bilgilerini kullanmalarına, iddialarını delillerle desteklemelerine ve sonuçlara ilişkin yansıtmada bulunmalarına vurgu yapmaktadır (Lankford, 2010). Amaçlanan bu süreçlerin öğrenciler tarafından uygulanabilmesine rehberlik edebilecek yeterlilikte fen bilimleri öğretmenlerine olan ihtiyaç her geçen gün daha da artmaktadır. Dahası fen bilimleri eğitiminde niteliği artırmaya yönelik çabaların merkezine, özellikle her kademede etkili fen öğretmenlerinin hazırlanması yerleşmiştir. Uluslararası alanda öğretmenlik mesleğinin standartları ile ilgili çalışmalar sürekli bir gelişim ve dönüşüm içindedir. Ancak genel olarak eğilimler değerlendirildiğinde; 1960'lı yılların davranış̧̧ anlayışı olan "öğretmenlik yeterliklerinin" tanımlanmasından, alan ile pedagojinin bütünleştiği "Pedagojik alan bilgisi (PAB)" anlayışına doğru bir dönüşüm yaşandığı görülmektedir (TED, 2009). PAB, öğretmenlerin ne öğreteceği ve nasıl öğreteceğini bütünleştiren bir bilgi formuna karşılık gelmektedir (Abell, 2007; Shulman, 1987). Bu tanım, öğretmenlerin derin bir konu alanı, program, öğrenciyi anlama, öğretim stratejileri, yöntemleri ve teknikleri ile değerlendirme stratejileri bilgisine sahip olmalarını gerektirmektedir (Jang, Tsai ve Chen, 2013; Magnusson, Krajcik ve Borko, 1999; Nilson ve Loughran, 2012; Park, Jang, Chen ve Jung, 2011). Fen bilimleri eğitiminde öğretmenlerin etkili birer model ve içerik uzmanı olarak ayrılmalarında onların sahip oldukları alan bilgisi, pedagoji bilgisi ve bunların harmanlanmış hali olan PAB önemli belirleyicidir (Hanuscin, Lee ve Akerson, 2010). Konu alanı ve pedagoji bilgisinin harmanlanmış şekli olan PAB, öğrenenlere ilişkin bilgiler, eğitimsel amaçlar, sınıf başarısına ilişkin yetenekler ve bağlamsal bilgiler gibi çeşitli öğrenme olguları etrafinda şekillenmektedir (Gess-Newsome, 1999; Grossman, 1990). Günümüzde fen bilimleri eğitimini geliştirme üzerine düşünen ve araştıran çevreler, öğretmen adaylarının üniversite eğitiminde edinmiş oldukları etkili deneyimlerin, gelecekte öğrencileri için anlamlı öğrenme firsatlarını sağlamadaki önemine her firsatta vurgu yapmaktadırlar. Bunun için fen bilimleri öğretmen adaylarının, konu alanı ve pedagoji bilgilerini nasıl uyumlu bir şekilde birleştireceklerini anlamaya firsat verecek lisans dönemi örnek uygulamalarının alan yazında tanımlanması oldukça önemlidir.

\section{Fen Bilimleri Öğretmenleri ve PAB'ın Kavramsallaştırılması}

Bu yüzyılın son çeyreğinde, araştırmacılar özellikle başarılı öğretim için öğretmenin sahip olduğu bilgi ve buna iliş̧kin inanışlarını biçimlendiren yapı olarak PAB kavramını tartışmaya başlamışlardır. PAB kavramını ilk tanımlayan kişi olan Shulman (1986), bu yapıyı "Özel konuların, problemlerin ve durumların nasıl organize olduğu, nasıl sunulduğu ve öğrencilerin farklı ilgi ve yetenekleri doğrultusunda nasıl uyarlandığını anlamada içerik ve pedagojinin bir harmanıdır (s. 9)" şeklinde tanımlamıştır. PAB, geleneksel olarak ayrılmış alan ve pedagojik bilgi tabanlarını etkili şekilde harmanlayan epistemolojik bir kavram olarak değerlendirilir (Mishra ve 
Koehler, 2006). Bunun yanında PAB kavramı, başka araştırmacılar tarafından süreç içerisinde birçok kez yeniden tartışılmış ve tanımlanmıştır (Abell, 2007; Geddis, 1993; Gess-Newsome, 1999; Grossman, 1990; Loughran, Berry ve Mullhall, 2006; Magnusson ve diğ., 1999; Mishra ve Koehler, 2006; Park ve Oliver, 2008; Veal ve MaKinster, 2001). Fakat bu tanımlamalar değerlendirildiğinde PAB üzerindeki genel kanı, "Bu yapının öğrencilere belirli bir alandaki konuyu öğretmede en iyi yolları organize edebilme biçimi” olduğudur (Loughran, Mulhall ve Berry, 2004). PAB öğretmenlerin etkili öğrenme ortamları oluşturmasına ve belirli bir konunun öğretiminde bilgilerini organize edebilmelerine rehberlik etmektedir (Bond-Robinson, 2005). Ayrıca öğretmenlerin bildiklerini ve zamanla nasıl geliştiğinin karmaşıklığını çözmeye yardım eden öğretmen bilgisi için önemli bir bulgudur (Schneider ve Plasman, 2011). Bu bağlamda düşünüldüğünde öğretmenin sahip olduğu PAB, öğrencilerin ihtiyaçlarına en uygun şekilde biçimlenmiş, öğretim faaliyetleri yoluyla anlamlı öğrenmenin gerçekleştirilmesine imkan tanıyan bir yapılanma olarak görülmektedir (Juang, Liu ve Chan, 2008).

Fen bilimleri eğitiminde öğretmenler için PAB'ın yol gösterici bir paradigma olabilmesi bu yapının kavramsal olarak diğer bilgi türlerinden ayırt edilmesini gerektirmektedir. Fen bilimleri öğretmenlerinin öğretme anlayışlarını yansıtan PAB, farklı bilgi boyutlarının etkileşimi sonucu ortaya çıkmaktadır. Alan yazında fen bilimleri öğretmeni veya öğretmen adaylarının PAB yapısını inceleyen araştırmacılar farklı bilgi boyutları üzerinden değerlendirmeler yapmışlardır (Appleton, 2008; Brown, Friedrichsen ve Abell, 2013; Henze, Van Driel ve Verloop, 2008; Jang, 2012; Kapyla, Heikkinen ve Asunta, 2009; Lee ve Luft, 2008; Park ve diğ., 2011; Weizman ve diğ., 2008). Bununla birlikte pek çok fen bilimleri eğitimi araştırmacısı, Magnusson, Krajcik ve Borko'nun (1999) PAB modelini kullanarak öğretmen ve öğretmen adaylarının sahip oldukları bilgi yapılarını inceledikleri görülmektedir (Faikhamta, 2013; Henze ve diğ., 2008; Weizman ve diğ., 2008). Magnusson ve diğerleri'nin (1999) PAB modeli, fen bilimleri eğitimi araştırmacıları için belki de en dikkat çekici tanımlama olmuştur. Araştırmacılar bu modelde fen bilimleri öğretmenleri için beş temel bilgi yapısını tanımlamışlardır. Bunlar: öğretim uyumu, program bilgisi, öğretim strateji, yöntem ve temsil bilgisi, öğrenciyi anlama bilgisi ve değerlendirme bilgisidir. Magnusson ve diğerleri'nin (1999) fen bilimleri öğretmenleri için ifade ettikleri PAB kavramsal modeli Şekil 1'de gösterilmiştir.

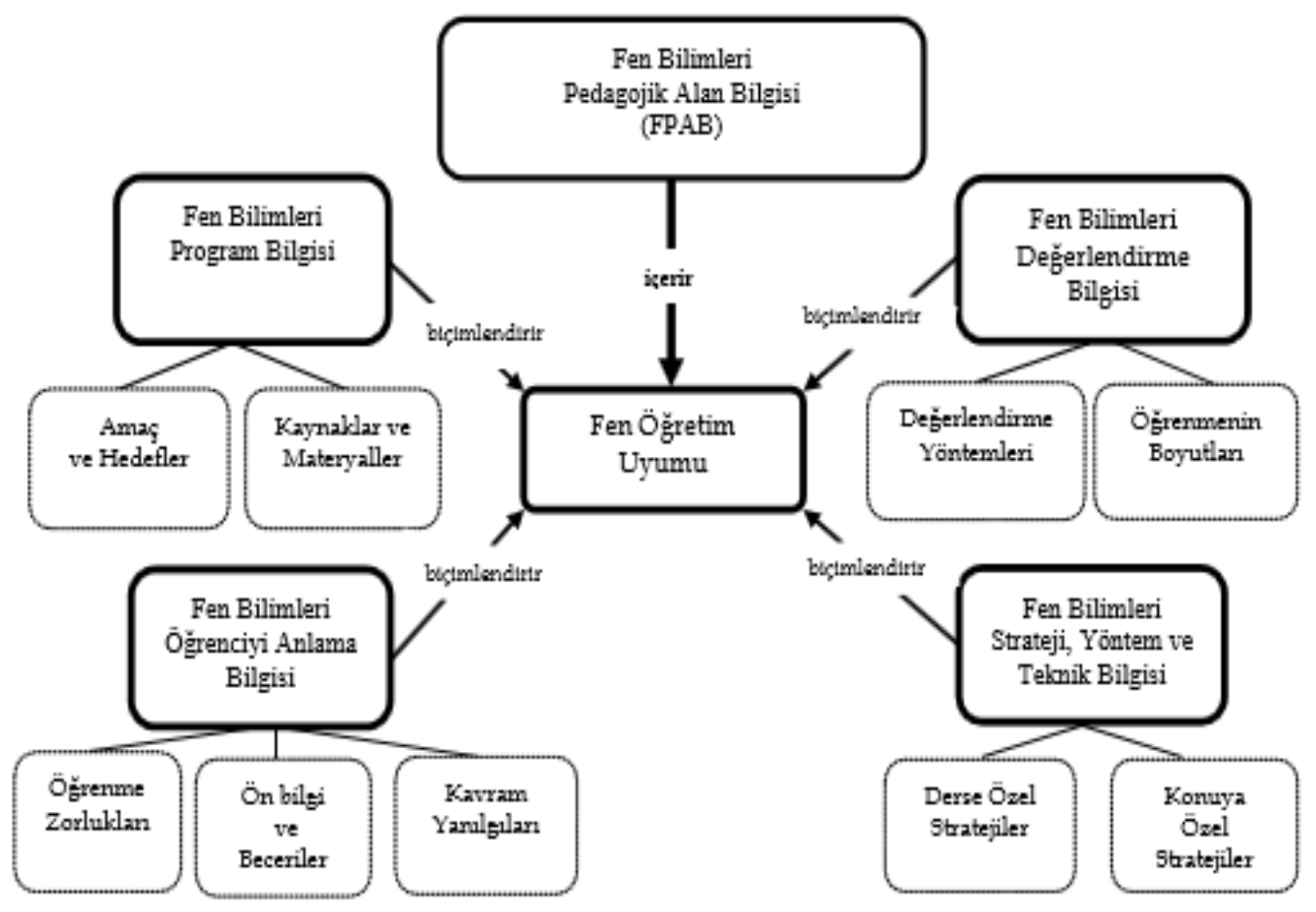

Şekil 1. Magnusson, Krajcik ve Borko'nun (1999) Fen Bilimleri Öğretimi PAB Modeli.

$\mathrm{Bu}$ modelde araştırmacılar, fen bilimleri öğretmenlerinin PAB yapısının, ayrı bilgi boyutlarının etkileşimi sonucu ortaya çıkan bir yapı olduğunu belirtmişlerdir. Bu yapı beş temel bilgi boyutundan oluşmaktadır. Bunlar:

- Öğretim uyumu: Fen bilimlerinin nasıl öğretilmesi gerektiğine ilişkin hedef ve amaçları ifade etmektedir.

- Program bilgisi: Farklı sınıf seviyelerinde dersin içeriğine özel amaç ve hedefler ile bu konuda öğrenmeyi destekleyecek çeşitli müfredat kaynaklarının farkındalığını içermektedir. 
- Öğrenciyi anlama bilgisi. Öğrencilerin konuları öğrenebilmesi için hangi ön bilgi ve beceriye sahip olmaları gerektiği, öğrenmelerini engelleyecek zorlukların ne olduğu ve kavram yanılgılarının neler olabileceğine ilişkin anlayışı içermektedir.

- Strateji, yöntem ve teknik bilgisi. Fen öğretiminde öğretmenin hangi yöntemleri kullanabileceğinin yanı sıra özel bir fen konusunu öğretirken kullanması faydalı olabilecek yöntemler hakkındaki anlayışını kapsamaktadır.

- Değerlendirme bilgisi. Bir konunun öğrenci tarafından ne kadar öğrenildiğini değerlendirmede hangi metotların uygun olduğuna ilişkin anlayışı ve bunlar hakkındaki görüşleri kapsamaktadır.

Magnusson ve diğerleri'nin (1999) modelinde diğer dört bilgi boyutunun etkileşimi sonucunda ortaya çıkan bir yapı olarak tanımlanan fen öğretim uyumu boyutu, Friedrichsen, Van Driel ve Abell (2011), tarafından öğretmen ve öğrencinin dersteki rollerinin tanımlandığı görüşler ile fen öğretimindeki hedef ve amaçlara ilişkin inanışlarının bir temsili şeklinde tanımlanmıştır. Anderson ve Smit (1987), bir öğretmenin sahip olduğu öğretim uyumu bileşenini ilk tanımlayan araştırmacılardır. Araştırmacılar bu bileşeni dört alt boyuta ayırmışlardır. Bunlar: bilgi verici öğretim, etkinlik güdümlü öğretim, keşfedici öğretim ve kavramsal değişim öğretimi. Magnusson ve diğerleri (1999), öğretim uyumu bileșenini Anderson ve Smith'in (1987) tanımlamaları üzerine beş yeni boyut ekleyerek yeniden inşa etmişlerdir. Bunlar: bilimsel süreç temelli, akademik sertlik, proje temelli, sorgulama ve rehberlikli sorgulama. Friedrichsen (2002), fen öğretim uyumuna ilişkin bu boyutları iki temel yapı içerisinde sınıflandırarak açıklamıştır. Bunlar: "öğretmen merkezli uyum" (bilgi verici öğretim, akademik sertlik) ve "reform temelli uyum". İkinci boyut içerisinde yeniden bir sınıflandırmaya gidilerek, 1960"ların reform çabaları üzerine öğretim uyumu (bilimsel süreç, etkinlik güdümlü öğretim, keşfetme) ve çağdaş reform çabalarına dayalı öğretim uyumu (kavramsal değişim, projeye dayalı öğretim, sorgulama ve rehberlikli sorgulama) olarak ayrılmıştır (Friedrichsen, Van Driel ve Abell, 2011). Magnusson ve diğerleri'nin (1999), fen öğretim uyumu modellemesindeki alt boyutlara ilişkin tanımlamalar şu şekildedir:

- Bilgi verici öğretim; öğretmen merkezli bir öğretim uyumu boyutu olan bu yapı, öğretmenin fene ilişkin bilgileri konferans ya da tartışma yoluyla öğrencilere sunmasıdır.

- Akademik katılık; öğretmen merkezli bir öğretim uyumu boyutu olan bu yapı, öğrencilere zor problem ve aktivitelerle meydan okumadır.

- Süreç Temelli; öğrencilerin bilimsel süreç becerileri geliştirmelerine yardım etmektir.

- Yaparak deneyimleme (Etkinlik güdümlü öğretim); öğrenci merkezli bir öğretme-öğrenme uyumu olan yaparak deneyimleme, öğrencilerin deneyler üzerine pratik yaparak, materyallerle aktif olarak çalışmalarıdır.

- Keşfetme; öğrenilmesi hedeflenen fen kavramlarının, öğrenciler tarafından keşfedilmesi için firsatlar sağlama ve öğrencilerin araştırmaları boyunca dünya nasıl işlerin örneklerini keşfetme ve kendi ilgilerine yönelerek doğal dünyayı anlamalarıdır.

- Kavramsal değişim; öğrencilerin yeni ve yapılanmamış fikirlerinin doğruluğunun tartışıldığı bir bağlam içerisinde bu fikirlerine ilişkin yüzleştirme yapılarak bilimsel bilginin yapılandırılmasıdır.

- Projeye dayalı fen; gerçek dünya problemlerinin çözümü için araştırma yapma sürecine öğrencilerin dahil edilmesidir.

- Sorgulama; öğretimin doğasını araştırma merkezli olarak nitelendiren bir anlayışı sunar.

- Rehberlikli sorgulama; bilimin araçlarını kullanarak fiziki dünyayı anlamada sorumluluk paylaşan üyelerin oluşturduğu bir öğrenenler topluluğuyla bilgiyi araştırmak ve yapılandırmaktır.

Fen bilimleri öğretmenlerinin öğretim uyumu hakkındaki incelemeler, öğrencilerin fen okur yazarlığını şekillendiren sınıf içi kararlar için önemli bilgiler sunmaktadır (Brown ve diğ., 2013; Campbell, Zuwallack, Longhurst, Shelton ve Wolf, 2014; Friedrichsen ve Dana, 2005; Park ve Oliver, 2008). Bu bakımdan fen bilimleri öğretmeni ve adaylarının PAB`ının tanımlanması ve yapılandırılması için öncelikle onların bilgi ve uygulamalarına iliş̧kin anlayışlarının sınırlarını çizen öğretim uyumlarının belirlenmesi gerekmektedir.

Fen bilimleri öğretmenlerini hazırlayan eğitimciler, adayların meslek öncesi kariyerlerinde alan ve pedagojik içerikte ustalaşmalarına yardım edecek öğrenme firsatlarıyla desteklemelidirler (Hume ve Berry, 2013; Schneider ve Plasman, 2011). Özellikle PAB'ın gelişimi öğrenme uygulamalarında gizlidir. Öğretmenler uygulamalar için harcadıkları zamanlarda düşüncelerini daha sofistik bir hale sokar ve mesleki gelişimlerini ilerletmek için daha gerçekçi bilişsel değerlendirmelere olanak bulurlar (Schneider ve Plasman, 2011). Bunun yanında yapılan bazı araştırmalar, öğretimde uzmanlık sergileyen fen bilimleri öğretmenlerinin PAB'ını 
keşfetme çalışmalarının da, aday öğretmenler için PAB'larını geliştirmede önemli faydalar sağlayacağını göstermektedir (Lee ve Luft, 2008). Ayrıca Loughran, Berry ve Mullhall (2006) uzman öğretmenlerin, aday fen bilimleri öğretmenlerinin PAB gelişimine yardımcı olacak pedagojik yaklaşımları açık hale getirmede mesleki deneyime sahip olduklarını belirtmektedirler. Bununla birlikte ilgili alan yazında aday fen bilimleri öğretmenlerinin PAB gelişimlerinin; deneyimli öğretmen gözlemleri, sınıf içi uygulamalar ve işbirlikli çalışmalar gibi farklı pratikler üzerinden araştırıldığı görülmektedir (Appleton, 2008; Bozkurt ve Kaya, 2008; Henze ve diğ., 2008; Kapyla ve diğ., 2009; Loughran ve diğ., 2004; Park ve Oliver, 2008; Timur, 2011).

\section{Fen Bilimleri Öğretmen Eğitimi ve Probleme Dayalı Öğrenme (PDÖ)}

Öğretmen eğitimi küreselleşme, kültürel farklılık, hızlı bilgi artışı ve bilgi teknolojilerinin gelişimine cevap vermede giderek daha yoğun bir baskı altında kalmakta ve bu durum öğretmenlerin eleştirel ve analitik beceriler geliştirmelerini gerektirmektedir (De Simone, 2008). Bugünün öğretmen eğitim programları, öğretmenin teknik olarak karar verici modelinden, yansıtıcı ve uygulayıcı öğretmen modeline doğru kaymıştır. Bu modelde öğretmeyi ömür boyu öğrenme işlemi olarak gören öğretmenler, yansıtıcı ve uygulayıcı olma becerilerini geliştirmek zorundadırlar (Beck, 2007; Campbell ve diğ., 2015; Dias, Eick ve Brantley-Dias, 2011; Seung, Park ve Narayan, 2011).

Fen bilimleri eğitiminde uzun zamandır devam eden reform çalışmalarının en temel amacı, öğrenci başarısını geliştirmeye yönelik öğrenme uygulamalarını sisteme dahil etmektir (McNall, Lott ve Wymer, 2009). Bu anlayış, dünyada bilginin araştırma, sorgulama ve kanıta dayalı anlamlandırıldığı eğitimsel paradigmalara yönelmeyi hedeflemektedir (Ruthven, 2011). Bu eğitimsel süreçler içerisinde öğrenenlerin kendilerine özgü bilgi yapılarını oluşturması ve gerçek yaşamın karmaşıklığını açıklığa kavuşturacak bilişsel yapılanmayı sağlamalarına rehberlik yapabilen öğretmenlerin yetiştirilmesi oldukça önemlidir (Yurdakul, 2010). Bugün fen bilimleri öğretmen eğitimi programları, adayları hazırlama, hızla değişen bilgiyi takip etme, hassas bir şekilde bilimsel ve sosyal konulara iliş̧in anlayış geliştirme ve bilimle ilgili hem evrensel hem de yerel anlamda düşünmeyi biçimlendirmede eşsiz zorluklara sahip bir süreci içermektedir (Hestness, Mcginnis, Riedinger ve Marbach-Ad, 2011). Reform yanlısı fen öğretmenlerinin yetiştirilmesi, ancak geleneksel normlara karşı çıkan ve yeni bir mesleki kimlik geliştirmeyi amaçlayan deneyimlerle mümkündür (Luehmann, 2007). Yore'ye (2001) göre, her öğretmen yetiştirme programı, eleştirel düşünme ve sorgulamanın bir parçası olmak zorundadır. Eleştirel düşünme ve sorgulama becerisi gelişmiş aday öğretmenler, karmaşık fen konularının öğretimine ilişkin problem durumunda, kendi eğitimsel çözümlerini etkili bir şekilde oluşturabilmektedirler. Dolayısıyla öğretmenlerin, fen öğretimine ilişkin sağlam bilgi yapıları oluşturmaları, ancak karmaşık öğrenme ve öğretme problemleri ve teorileri üzerinde çalışmaları yoluyla mümkün hale gelebilir (Traianou, 2006).

PDÖ, eğitimde uygulanmış en yaratıcı pedagojik yöntemlerden biridir. PDÖ’nün temelleri Dewey'in "Yaparak ve Deneyerek Öğrenme" yaklaşımına dayanmaktadır (Dewey, 1938). Ayrıca Vygotsky'nin 1978'deki sosyal öğrenme teorisiyle desteklenen PDÖ yenilikçi bir öğrenme metodudur (Baturay ve Bay, 2010; Hmelo-Silver ve Barrows, 2006). PDÖ öğrenenlerin problem çözme yeteneklerini ve bilgilerini geliştirmek için gerçek dünya problemlerinin kullanıldığı pedagojik bir yaklaşımdır (Albanese ve Mitchell, 1993; Hmelo-Silver, 2004; Weizman ve diğ., 2008). Problem merkezli öğrenme ortamlarında, öğrenenler gerçek bir bağlam içeren problem üzerine çalışırken kendi içerik bilgileri ve becerilerini uygulama fırsatlarına sahip olurlar (Dunlap, 2005). PDÖ uygulamalarının içeriği, pratik deneyimlere dayanan pedagojik bir vizyon olarak birçok alanda öğrencinin öğrenme sonuçlarına ilişkin (problem çözme, eleştirel düşünme, motivasyon, bilgiyi sürdürme) başarısını yansitmaktadır (Pierrakos, Zilberberg ve Anderson, 2010). Barrows (2002), PDÖ’nün kilit önemini şu şekilde tanımlamaktadır; "Öğrenenlerin öğrenmek için neye ihtiyaç duyduklarını kararlaştırdıkları ve kayıp bilginin peşinden gittikleri çoklu bilişsel süreçlerdir.” Bunun yanında PDÖ’nün asıl özelliği, ortaya koyulan problem durumlarının bir formülle ya da bir doğru cevap verilerek çözümlenmesi değil, problemlerin gerçek yaşam durumlarıyla ilişkilendirilerek çözümlendiği oluşumlardır (Pease ve Kuhn, 2011).

PDÖ büyük ölçüde ilgi duyulan bir yöntem olarak özellikle de fen bilimleri eğitiminde dikkatleri üzerine çekmiştir (Duschl, 2008). PDÖ, fen bilimleri eğitiminde karmaşık olayların çözümlenmesinde öğrenenin ilgisini artıran bir yöntem olarak karşımıza çıkmaktadır (Goodnough ve Cashion, 2006). Çoğunlukla gerçek dünya problemleri bağlamında fen bilimleri eğitimini yapılandırmak için uygulanmaktadır. PDÖ’nün fen bilimleri eğitimine en büyük katkısı, öğrenenlerin mevcut bilgisini yeni bilgileriyle birleştirmelerine imkân vermesidir (Pepper, 2009). PDÖ, özellikle lisans düzeyinde fen bilimleri öğretmen adaylarının anlayışlarını geliştirme ve mesleki eğitimlerinin nasıl ilerleyeceğini keşfetmede önemli bir pedagojik yapılanmayı ortaya koymaktadır (Goodnough, 2006). PDÖ, öğretmen adaylarının öğretim planlamaları ve tasarımları için kendi bilgi yapılarını gözden geçirme ve yapılandırmada bir araç olarak hizmet edebilir. Aynı zamanda PDÖ, öğretmen adaylarının özel bir disiplinle ilgili kavramları ve düşünceleri incelemesine ve bunu öğrenci anlayışını desteklemek için nasıl kullanması gerektiğine ilişkin bilişsel yapılanmayı da teşvik etmektedir (Goodnough ve Nolan, 2008). LoucksHorsley ve diğerleri (2010) öğretmenlerin PDÖ uygulamalarıyla, öğretim uygulamalarına ilişkin durumları 
sorgulayan ve işbirlikli öğrenme toplulukları yoluyla düşüncelerini paylaşan daha etkili uygulayıcılar olabildiklerini ifade etmişlerdir.

Son yıllarda PDÖ, çıkış noktası olan tıp okullarında olduğu gibi hizmet öncesi dönem öğretmen hazırlığında da etkili bir şekilde kullanılmaya başlanmıştır (Goodnough ve Hung, 2008; McConnell ve diğ., 2008; Weizman ve diğ., 2008). Bu kapsamda ilgili alan yazın incelendiğinde fen bilimleri öğretmen eğitiminde PDÖ’nün etkisini araştıran pek çok çalışma karşımıza çıkmaktadır (Goodnough, 2006; Hung, 2006; Major ve Mulvihill, 2018; McConnell, Parker ve Eberhardt, 2013; Shin ve diğ., 2010; Sungur ve Tekkaya, 2006; Weizman ve diğ., 2008). $\mathrm{Bu}$ araştırmalardan McConnel ve diğerleri $(2008,2013)$, PDÖ'yü fen bilimleri öğretmenleri için alan ve pedagojik bilgiyi öğrenmelerine rehberlik etmede kullanılabilecek bir yöntem olarak sunmuşlardır. Araştırmacılar bu çalışmalarında fen öğretmenlerinin, öğretimlerini analiz etmek ve geliş̧irmek için sorgulama temelli bir pedagojik anlayışın uygulanmasına ilişkin örnekler ortaya koymuşlardır. Yine Weizman ve diğ., (2008), fen bilimleri öğretmenlerinin öğretim bilgisini geliştirmede bir araç olarak PDÖ'nün nasıl kullanıldığını gösteren en kapsamlı araştırmalardan birisini yapmışlardır. Araştırmacılar, PDÖ'nün tıp eğitiminde olduğu gibi öğretmen eğitiminde de etkili bir şekilde kullanılabileceğini göstermişlerdir. Weizman ve diğerleri (2008), her iki meslek grubu bakımından PDÖ'nün uygulanmasındaki benzerliği şu şekilde ifade etmişlerdir; "Doktorların ve fen bilimleri öğretmenlerinin olgulara ilişkin aldıkları kararlar bağlamında, farklılıklar olmasına rağmen (doktorların kararları genellikle bireysel hastalarla, fen öğretmenleri ise farklı ihtiyaç ve hedefleri olan öğrenci gruplarıyla ilgilidirler), aynı zamanda pek çok benzerlikleri de vardır." (s. 4). Araştırmacılar her iki meslek grubundaki bireylerin PDÖ uygulamaları bağlamında benzer yanlarını şöyle tanımlamaktadırlar:

- Güçlü kavramsal anlayış; doktorlar doğru teşhisi koymak için hızlı ve kesin bir şekilde hatılanabilen güçlü bir tıp bilgisi anlayışına ihtiyaç duymaktadırlar. Benzer şekilde öğretmenlerde öğreteceği geniş ve derin konu alan bilgisi anlayışına ihtiyaç duymaktadır.

- Bilgiyi uygulama yeteneği; yeni ve beklenmedik bağlamlar içerisinde bilgiyi hatırlama ve uygulama yeteneği, çalışmalar içerisinde problemlerin çözümü için gereklidir.

- Eksik bilgiyle düşünme yeteneği; sadece birkaç gerçeği bilerek, doktorlar tipik olarak sorular sorar ve daha fazla bilgi elde etmek için birkaç test sıralarlar. Öğretmenler de benzer görevlerle karşı karşıya gelirler. Öğretmenler, öğrencileri için en iyi olabilecek öğrenme durumlarının ne olduğuna ilişkin karar almalarında, öğrencilerin bilgileri, motivasyonları ve bireysel öğrenme ihtiyaçları hakkında sınırlı bilgiyi kullanmak zorundadırlar.

- Kendi kendine bağımsız öğrenme motivasyonu; tıp okullarında uygulama içinde bir kez edindiği bilgiye bel bağlamayan doktorlar gibi öğretmenlerde öğreteceği konu üzerinde güncelleme yapmak zorundadır. Dahası öğretmenlerin eğitim standartlarındaki değiş̧imler ve fen bilimleri eğitimi hakkındaki güncel düşüncelerden haberdar olmaya ihtiyaçları vardır.

\section{Çalışmanın Amacı ve Problem Durumu}

İlgili alan yazın incelendiğinde fen bilimleri öğretmen eğitimine ilişkin birçok hizmet öncesi mesleki gelişim uygulama örneği sunulmaktadır. Bu uygulamalara baktığımızda birçoğunun fen bilimleri öğretmenleri ve adaylarının alan bilgileri ve pedagoji bilgilerine ilişkin mevcut durumu tespit ettikleri görülmektedir (Demirdöğen, Hanuscin, Uzuntiryaki-Kondakçi ve Köseoğlu, 2016; Großschedl, Harms, Kleickmann ve Glowinski, 2015; Fraser, 2016; Karal ve Alev, 2016; Mavhunga ve Rollnick, 2016; Mthethwa-Kunene, Onwu ve Villiers, 2015; Sinelnikov ve diğ., 2015). Bunun yanında son yıllarda yine birçok uluslararası çalışmanın, özel bir fen konusu bağlamında aday öğretmenlerin PAB yapısını geliştirmeyi amaçlayan mesleki uygulamaları içerdiği anlaşılmaktadır (Akerson ve diğ., 2015; Appleton, 2008; Barnett ve Friedrichsen, 2015; Bertram ve Loughran, 2012; Brown ve diğ., 2013; Cite, Lee, Menon ve Hanuscin, 2017; Chan ve Yung, 2015; Faikhamta, 2013; Henze ve diğ., 2008; Iserbyt, Ward ve Li, 2015; Nilson ve Loughran, 2012; Nilsson ve Vikström, 2015; Taber, 2014; Weizman ve diğ., 2008). Bu çalışmalarda daha çok araştırma, sorgulama, tartışma, problem ve proje temelli öğrenme yöntemleriyle fen bilimleri öğretmen adaylarının PAB yapılarının geliştirilmesi amaçlanmıştır (De Simone, 2008; McConnell ve diğ., 2013; Weizman ve diğ., 2008; Zhang ve diğ., 2010). Ancak ulusal çalışmalar incelendiğinde ise bir çoğunun fen bilimleri öğretmenleri ve adaylarının mevcut alan bilgisi, pedagoji bilgisi ve PAB yapısına ilişkin durum tespiti çalışmalarını içerdiği anlaşılmaktadır (Bardak ve Karamustafaoğlu, 2016; Bozkurt ve Kaya, 2008; Canbazoğlu, 2008; Canbazoğlu, Demirelli ve Kavak, 2010; Kartal, Yamak ve Kavak, 2017; Mıhladız, 2010; Mıhladız ve Tımur, 2011). Bunun yanında öğretmen adaylarının PAB yapılarını geliştirmeye yönelik deneysel çalışmaların çok sınırlı sayıda kaldığı görülmektedir (Timur, 2011). Ayrıca bu çalışmalar incelendiğinde, fen bilimleri öğretmen adaylarının PAB yapılarını geliştirmek için problem temelli bir mesleki gelişim uygulamasını içermedikleri görülmüştür. İfade edilen bu açıklamalara dayalı olarak fen bilimleri öğretmen adaylarının lisans dönemi hazırlıklarında PAB yapılarını sorgulayıp, geliştirebilmelerine olanak sağlayacak mesleki öncesi deneyimlere ihtiyaç vardır. Dolayısıyla bu çalışmanın 
amacı, öğretim süreçleri içerisinden alınmış pedagojik problem durumlarının kullanıldığı PDÖ uygulamalarının fen bilimleri öğretmen adaylarının PAB gelişimlerine olan etkisini araştırmaktır. Bu kapsamda ilk olarak iki ayrı öğrenme grubu oluşturularak, PDÖ uygulamalarının fen bilimleri öğretmen adaylarının PAB gelişimi üzerine etkisinin deneysel olarak sınanması amaçlanmıştır.

$\mathrm{Bu}$ amaç doğrultusunda aşağıdaki araştırma problemlerine yanıt aranmıştır:

1. PDÖ uygulamalarının fen bilimleri öğretmen adaylarının öğretim uyumu gelişimlerine etkisi nedir?

2. PDÖ uygulamalarının fen bilimleri öğretmen adaylarının program bilgisi gelişimine etkisi nedir?

3. PDÖ uygulamalarının fen bilimleri öğretmen adaylarının öğretim stratejisi, yöntem ve teknik bilgisi gelişimine etkisi nedir?

4. PDÖ uygulamalarının fen bilimleri öğretmen adaylarının öğrenciyi anlama bilgisi gelişimine etkisi nedir?

5. PDÖ uygulamalarının fen bilimleri öğretmen adaylarının değerlendirme bilgisi gelişimine etkisi nedir?

$\mathrm{Bu}$ araştırma, fen bilimleri öğretmen adaylarının PAB yapısının, PDÖ süreçleri içerisinde sorgulama ve araştırma yollarını kullanarak nasıl şekillendiğini ve öğretimsel kararların ne tür deliller yoluyla alındığına ilişkin deneysel uygulama örneğini sunmaktadır.

\section{Yöntem}

\section{Araştırmanın Deseni}

$\mathrm{Bu}$ araştırma, PDÖ yönteminin fen bilimleri öğretmen adaylarının PAB gelişimine etkisi inceleyen deneysel bir çalışmadır. Bu araştırmada ön test-son test eşleştirilmiş kontrol gruplu seçkisiz (sistematik) deneysel desen kullanılmıştır. Ön test-son test kontrol gruplu seçkisiz desen, bir gruba yapılan uygulamanın etkisinin ön ve son ölçüm puanları ile karşılaştırılmasıdır (Cohen, Manion ve Morrison, 2007). Deneysel desen, neden ve sonuç ilişkisini test etmenin en güvenilir yoludur (Fraenkel ve Allen, 2006). Bu desen, uygulama gruplarının denk olma olasılığını artırmak için kullanılmaktadır. Bunun için öncelikle geçmiş ilgili araştırma sonuçları, araştırmacının deneyimleri ve ön test puanları dikkate alınarak denek çiftleri oluşturulur. Daha sonra oluşturulan bu çiftler deney ve kontrol gruplarına seçkisiz olarak dağıtılır (Büyüköztürk ve diğ., 2010). Araştırmanın deneysel tasarım modeli Şekil 2'de gösterilmiştir.

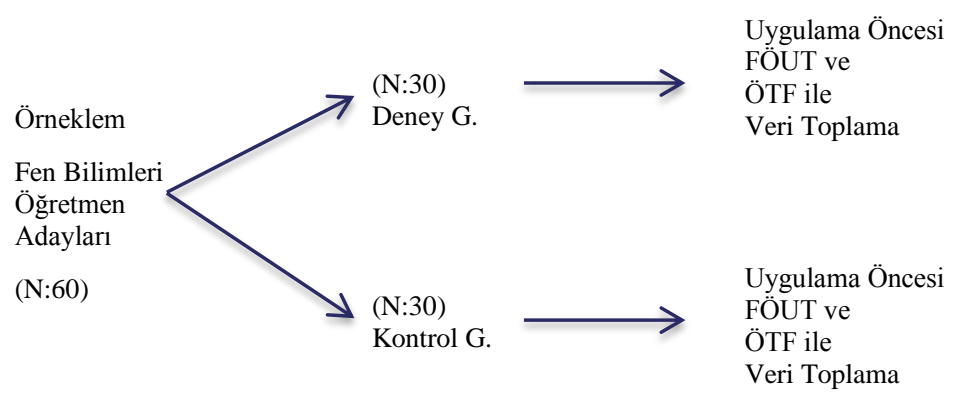

Şekil 2. Araştırmanın Desenine İlişkin Model.

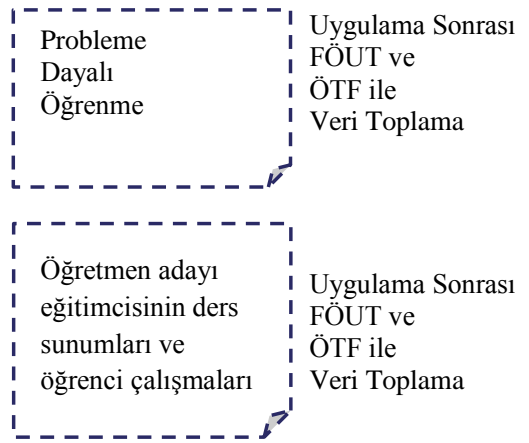

$\mathrm{Bu}$ araştırmada fen bilimleri öğretmen adaylarının PAB gelişimlerine ilişsin detaylı veri elde etmek için hem nicel hem de nitel verilerin bir arada kullanıldığı karma yöntem tercih edilmiştir. Karma yöntem pragmatik bir zemin üzerinde bilgi iddiaların temellendirme eğilimi olarak tanımlanmaktadır (Creswell, 2003). Bu bağlamda karma yöntem bir dizi çalışma içerisinde nicel ve nitel verilerin toplanması, analiz edilmesi ve yorumlanmasını içeren araştırmaları temsil etmektedir (Leech ve Onwuegbuzie, 2009). Bu araştırmada PDÖ uygulamalarının fen bilimleri öğretmen adaylarının PAB gelişimleri üzerindeki etkisini belirlemek amacıyla iç içe geçmiş karma model tasarımı kullanılmıştır. Cresswell ve Clark (2007) iç içe geçmiş karma modeli, deneysel bir uygulama öncesi ve sonrası elde edilen nicel verilere ek olarak uygulama grubundan uygulama öncesi ve sonrasında nitel veriler toplanarak bu iki veri türünün birbirine destek sağlaması olarak tanımlamışlardır.

\section{Çalışma Grubu}

Bu araştırmanın çalışma grubunu, bir devlet üniversitesinin fen bilimleri öğretmenliği programı üçüncü sınıfında öğrenim gören toplam 60 öğretmen adayı oluşturmaktadır. Deney ve kontrol grubu olmak üzere her iki uygulama grubuna 30' ar öğretmen adayı seçilmiştir. Deney gurubu 17 kız, 13 erkek, kontrol grubu 15 kız, 15 erkek öğretmen adayından oluşmuştur. Uygulama gruplarının belirlenmesinde seçkisiz olmayan örnekleme 
yöntemlerinden sistematik seçim yöntemi kullanılmıştır. Bu örneklemede bireyleri seçerken belirli ölçütlere göre oluşturulmuş sistematik bir yöntem kullanılır (Büyüköztürk ve diğ., 2010; Şenol, 2012; Yıldırım ve Şimşek, 2011). Bu kapsamda uygulama gruplarının denk olmasında ölçüt birim olarak adayların altı yarıııl sonundaki akademik başarı puanı ortalamaları dikkate alınmıştır. Gruplara seçim için öğretmen adayları akademik başarı puanı ortalamalarına göre en yüksekten başlayarak aşă̆ıya doğru sıralanmıştır. Bu sırlama içerisinde en yüksek ortalama puana 3.62, en düşük ortalama puanın ise 2.08 olduğu görülmüştür. Bu sıralamanın ardından deney ve kontrol grupları ilk aşamada A ve B grubu olarak isimlendirilmiştir. Bu iki gruba örneklem seçimi yapıldıktan sonra yine olasılık temelli bir seçim yapılarak deney (B) ve kontrol (A) grupları olarak belirlenmiștir. Bu örneklem seçim işleminde akademik ortalaması en yüksek ilk seçilen öğretmen adayı A grubuna, ardından ikinci en yüksek akademik ortalamaya sahip öğretmen adayı B grubuna olacak şekilde sırasılyla tüm örneklem bu sistematiğe uygun bir şekilde dağıtılmıştır. Seçim işlemi sonunda deney grubunda yer alan öğretmen adaylarının tümünün akademik puan ortalaması 2.67, kontrol grubunda yer alan adayların ise 2.74 olarak hesaplanmıştır.

\section{Uygulama Süreci}

PAB, konu alanı ve pedagoji olmak üzere iki ayrı bilgi boyutunun en etkili şekilde harmanlandığı yapıyı ifade etmektedir. Bu kapsamda araştırmada fen bilimleri öğretmen adaylarının konu alanı ve pedagojik bilgisi gelişimlerine PDÖ yönteminin etkisini sınamak amacıyla lisans programının yedinci dönemde okutulmakta olan İnsan Anatomisi ve Fizyolojisi ile Özel Öğretim Yöntemleri dersleri seçilmiştir. Konu alan bilgisi için içerik olarak vücudumuzdaki sistemler, Pedagoji bilgisi için ise ögrretim uyumu, program, ögrrenciyi anlama, strateji, yöntem ve teknik ile değerlendirme bilgisi konuları belirlenmiştir. Deney grubunda yer alan öğretmen adaylarından uygulama öncesinde beşer kişiden oluşan altı PDÖ grubu oluşturulmuştur. Deney grubu öğretmen adayları insan anatomisi ve fizyolojisi ile özel ögretim yöntemleri derslerinde her hafta biri konu alanı biride pedagojik olmak üzere iki adet problem senaryosu üzerinde çalışmışlardır. Alan bilgisi derslerinde kullanılan problem senaryoları vücudumuzdaki sistemler konularına ilişkin olarak ders kitapları, tıp ve sağlık alanındaki kaynaklar ve uygulamanın yapıldığı programda on yıl boyunca bu dersi yürütmekte olan bir eğitimcinin desteği alınarak sinir, endokrin, sindirim, dolaşım, solunum, boşaltım olmak üzere altı içerikte hazırlanmıştır. Alan eğitimi dersi problem senaryoları ise yoğun bir alan yazın taraması yapılarak hazırlanmıştır (Abell, Appleton ve Hanuscin, 2010; McConnel ve diğ., 2008; Mc Connell, Parker ve Eberhardt 2013; Shin ve diğ., 2010; Torp ve Sage, 2002; Weizman ve diğ., 2008). Bu kapsamda alan eğitiminde kullanmak için problem senaryoları, yurtdışında fen bilimleri öğretmen adaylarını $\mathrm{PAB}$ eğitiminde kullanılan öğretim problem senaryoları örnek alınarak hazırlanmıştır (bkz. Ek A). Hazırlanan problem senaryoları PAB alt bileşenlerine odaklanarak hazırlanmış olup, fen derslerine ilişkin öğrenme-öğretim kesitlerine dayanmaktadır. Bu problem senaryoları, öğretmen adayları için öğretmen ve öğrenci aksiyonları, fen bilimlerinde bilginin yapılandırılması, program, öğrencilerin kavram yanılgıları ve öğrenme zorlukları, öğretimde yöntem ve teknikler ile öğrenci değerlendirmesi üzerine kurgulanmıştır. Deney grubunda yer alan öğretmen adayları, internet üzerinden açılmış olan "Fen Bilimleri Öğretmen Adayı Ĕ̈itiminde PDÖ Deneyimleri" isimli bir grup sayfası aracıllı̆ıyla her hafta iki problem senaryosuna erişmiş̧erdir. Bu grup sayfası aynı zamanda uygulama öncesinde iki hafta boyunca PDÖ yöntemine ilişkin uygulama örneklerini sunan videoların gösterilmesi ve bu örneklere ilişkin öğrenci düşüncelerinin paylaşılması amacıyla da kullanılmıştır. Ayrıca öğretmen adayları PDÖ uygulama raporlarını da bu sayfa aracılığıyla araştırmacıya ulaştırmışlardır. Bu grup sayfası aynı zamanda deney grubundaki tüm öğretmen adaylarının haftalık problem senaryosuna ulaşıp ulaşmadıklarına ilişkin olarak araştırmacıya fikir vermiştir. Yine araştırmacı haftalık problem senaryosunu incelemeyen öğretmen adaylarına bu sayfa üzerinden uyarı mesajı göndermek yoluyla iletişime geçmiştir. PDÖ grupları uygulama yapılan her iki ders içinde yeni bir problem senaryosuna önceki haftaki problem senaryosu çözüm raporunu teslim etmelerinin ardından ulaşmışlardır. Deney grubu öğretmen adayları her iki ders için kullanılan problem senaryolarına ilişkin toplamış oldukları bilgileri tartışmak ve problem çözüm raporlarını sunmak için diğer problem senaryosuna geçmeden bir gün önce kendileri için ayrılan iki saatlik oturumlara katılmışlardır. Deney grubunda yer alan öğretmen adaylarının insan anatomisi ve fizyolojisi ile özel öğretim yöntemleri dersleri için kullandıkları PDÖ süreçleri Tablo 2'de gösterilmiştir. Deney grubunda yer alan fen bilimleri öğretmen adayları haftalık problem senaryoları üzerinde çalıştıktan sonra ortaya birden fazla ikilem ve hipotez ortaya koymuşlardır. Ancak nihai araştırma sürecinde sadece bu ikilem ve hipotezlerden birisini dikkate alarak deliller toplamışlardır. Örnek ikilem ve hipotezler Tablo 1'de gösterilmiştir.

Grup üyeleri pedagojik problemin çözümüne ilişkin ortaya koydukları hipotezi test etmede üyelerden birini öğretim uygulaması için seçmişlerdir. PDÖ grupları, arkadaşlarının öğretim uygulamalarını kaydederek, daha sonrasında bu kayıtları, hipotezlerini değerlendirmek için kullanmışlardır. Bunun yanında ayrıca PDÖ grupları problem çözümü için deneyimli öğretmenler, uzman öğretmen eğitimcileri ve çeşitli kaynaklardan bilgiler toplamışlardır. Uygulamanın son aşamasında PDÖ grupları, araştırma süresince topladıkları delilleri analiz etmek için bir araya gelmişlerdir. Uygulamalar sonucunda tüm PDÖ grupları bir araya gelerek kendi ikilemlerini, hipotezlerini ve delillerini birbirleriyle paylaşmışlardır. Deney grubunun pedagojik problem üzerinde çalışma süreçlerine iliş̧in döngü Şekil 3’te gösterilmiştir. 
Tablo 1

PDÖ Gruplarının Problem Senaryolarına İlişkin İkilem ve Hipotez Örnekleri

\begin{tabular}{|c|c|}
\hline İkilem & Hipotez \\
\hline $\begin{array}{l}\text { "Öğrencilerin ön bilgilerini ve kavram yanılgılarını } \\
\text { sorgulamada onları özel pedagojik uygulamalara nasıl } \\
\text { yönlendirebiliriz?" }\end{array}$ & $\begin{array}{l}\text { "Eğer biz öğrencilerimiz için keşfetme ve sorgulama temelli } \\
\text { öğrenme deneyimlerini dersle bütünleştirirsek, onlar öğrenim } \\
\text { aşamaları boyunca var olan eksik ve yanlış bilgileri üzerine } \\
\text { çıkarım yapma imkânı bulacaklardır." }\end{array}$ \\
\hline $\begin{array}{l}\text { "Öğrencilerin konuya ilişkin bilgi ve kavramları } \\
\text { yapılandırmalarında doğrudan düzenleyiciler olmaları } \\
\text { için değerlendirme aktivitelerini nasıl kullanabiliriz?" }\end{array}$ & $\begin{array}{l}\text { "Eğer biz dersin hedefleriyle bağlantılı olarak öğrencilerin } \\
\text { öğrenmeleriyle ilgili dersin belirli aşamalarda teşhis edici } \\
\text { değerlendirme tekniklerini kullanırsak, öğrenciler kendi } \\
\text { öğrenmeleri hakkında sorgulama imkânı bulacaklardır." }\end{array}$ \\
\hline
\end{tabular}

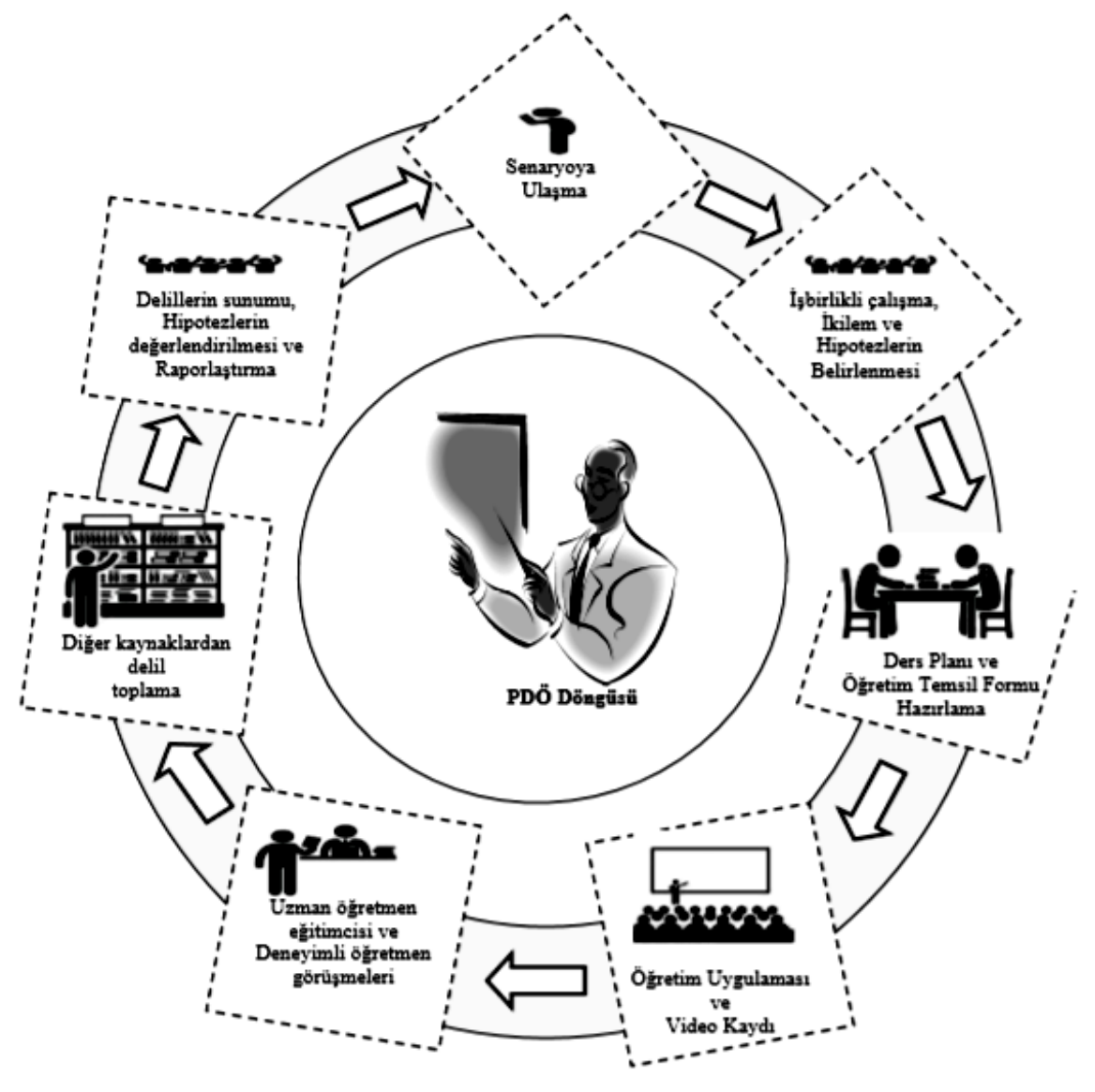

Şekil 3. PAB Gelişimi PDÖ Deneysel Tasarım Modeli (Çizimler www.canstockphoto.com adresinden alınmıştır.)

Tablo 2

Insan Anatomisi ve Fizyolojisi ile Özel Öğretim Yöntemleri Derslerindeki PDÖ Süreçleri

\begin{tabular}{|c|c|}
\hline $\begin{array}{l}\text { Konu Alanı Dersi } \\
\text { (İnsan Anatomisi ve Fizyolojisi) }\end{array}$ & $\begin{array}{l}\text { Alan Eğit } \\
\text { (Özel Öğg }\end{array}$ \\
\hline $\begin{array}{l}\text { Aşama 1. Grup üyelerinin problem senaryosunu } \\
\text { okumaları } \\
\text { Aşama 2. Başlangıç grup tartışmaları } \\
\text { - Senaryoya ilişkin ne bilmekteler? } \\
\text { - Senaryonun çözümü için neyi bilmeye } \\
\text { ihtiyaçları var? } \\
\text { Problem durumuna ilişkin hipotezlerin } \\
\text { kurulması? }\end{array}$ & $\begin{array}{l}\text { Aşama 1. Problem Senaryosu Üzerinde Çalışma } \\
\text { - PDÖ gruplarının problem senaryosunu okuma ve } \\
\text { anlamaları } \\
\text { - Problem senaryosuna ilişkin ikilemlerin oluşturulması } \\
\text { - Probleme ilişkin öğretim hipotezlerinin kurulması } \\
\text { - Hipotezleri test edilmesi için uygulama planının } \\
\text { hazırlanması }\end{array}$ \\
\hline
\end{tabular}


Tablo 2 -Devam

\begin{tabular}{|c|c|}
\hline $\begin{array}{l}\text { Konu Alanı Dersi } \\
\text { (İnsan Anatomisi ve Fizyolojisi) }\end{array}$ & $\begin{array}{l}\text { lan Eğitimi Dersi } \\
\text { Özel Öğretim Yöntemleri) }\end{array}$ \\
\hline $\begin{array}{l}\text { Aşama 3. PDÖ Grubu üyelerinin bireysel olarak } \\
\text { problemin çözümü için gerekli ön bilgiler üzerinde } \\
\text { çalışmaları } \\
\text { Aşama 4. İkinci grup tartışmaları } \\
\text { • Probleme ilişkin şuanda ne bilmekteler? } \\
\text { • Grup üyelerinin hala neyi bilmeye ihtiyaçları } \\
\text { var? } \\
\text { Hipotezlerin yeniden gözden geçirilmesi ve } \\
\text { düzeltilmesi, } \\
\text { Öğrenme konularının öncelik sırasına karar } \\
\quad \text { vermek ve araştırma görevlerini tanımlamak. } \\
\text { Aşama 5. Araştırma sürecinin gerçekleştirilmesi } \\
\text { (İnternet, kütüphane, uzman görüşmeleri ve deneysel } \\
\text { aktiviteler) } \\
\text { Aşama 6. Grup üyelerinin araştırma bulgularını işleme } \\
\text { koymak için toplanması } \\
\text { Aşama 7. Öğrenme konularının yeniden gözden geçirme } \\
\text { Aşama 8. Amaçlar ve tavsiye edilen eylemlerin } \\
\text { savunulması } \\
\text { Aşama 9. Hipotezlerin desteklenmesi veya çürütülmesi } \\
\text { için öğrenilen bilgiler ışı̆ğında tartışma } \\
\text { Aşama 10. Sonuçların özetlenmesi ve çözüm raporunun } \\
\text { sunulması aşamalarını içermiştir }\end{array}$ & $\begin{array}{l}\text { Aşama 2. Öğretim Kararı Alma Döngüsü } \\
\text { - PDÖ gruplarının konulara ilişkin ortak ders planı } \\
\text { hazırlaması } \\
\text { - PDÖ gruplarının öğretime ilişkin büyük fikirlerini } \\
\text { belirlenmesi (Öğretim temsil formunun doldurulması) } \\
\text { - PDÖ gruplarından bir fen bilimleri öğretmen } \\
\text { adayının öğretim uygulamasını gerçekleştirmesi } \\
\text { - Öğretim uygulamasına ilişkin video kayıtlarının } \\
\text { alıması } \\
\text { Aşama } 3 . \text { Dış Destek Toplantıları } \\
\text { - Fen öğretmen eğitimcisi uzman desteği } \\
\text { - Deneyimli fen öğretmenleriyle görüşmeler } \\
\text { Aşama 4. Delillerin İşlenmesi } \\
\text { - Öğretim uygulaması video kayıtlarının izlenmesi ve } \\
\text { analizi } \\
\text { - Ders planları ve içerik temsili formlarının gözden } \\
\text { geçirilmesi } \\
\text { - Grup delillerinin sunulması } \\
\text { Deliller 1şı̆̆ında test edilen hipotezlerin gözden } \\
\text { geçirilmesi } \\
\text { PDÖ gruplarının ortaya koymuş oldukları } \\
\text { dilemmaları çözmek için geliştirmiş, oldukları yeni } \\
\text { stratejilerin tartışılması } \\
\text { Araştırma sonuçlarının raporlaştırılması }\end{array}$ \\
\hline
\end{tabular}

Kontrol grubunda yer alan öğretmen adayları ise hem insan anatomisi ve fizyolojisi hem de özel öğretim yöntemleri derslerinde konu alanı ve pedagoji bilgilerini sorumlu öğretim elemanının ders anlatımları ve kendilerinin aktif uygulamalarıyla biçimlendirmişlerdir. Dersten sorumlu öğretim elemanı kontrol grubunda insan anatomisi ve fizyoloji dersinin konu içeriğini kendisi anlatmış ayrıca öğrenciler ile karşılıklı soru cevap şeklinde devam eden süreçlerle ders işlemiştir. Özel öğretim yöntemleri dersinde ise öğretim elemanı her hafta konu içeriğini öğrencilere anlatmış, ardından konu içeriklerini kapsayan ders içi uygulamalar ve öğrenci ödevleriyle süreci yürütmüşlerdir.

\section{Verilerin Toplanması}

Araştırmada veri toplama aracı olarak; Fen Öğretim Uyum Testi (FÖUT) ve Öğretim Temsil Formu (ÖTF) kullanılmıştır. Tablo 3'te bu araştırmada kullanılan veri toplama araçlarının PAB'a ilişkin hangi bilgi boyutunu ölçmede kullanıldı̆̆ gösterilmiştir.

Tablo 3

Araştırmada Kullanılan Veri Toplama Araçları ve İnceledikleri PAB Boyutları

\begin{tabular}{lll}
\hline \multirow{2}{*}{ Bilgi Boyutu } & \multicolumn{2}{l}{ Veri Kaynakları } \\
\cline { 2 - 3 } & $\begin{array}{l}\text { Fen Öğretim Uyumu } \\
\text { Testi (FÖUT) }\end{array}$ & $\begin{array}{l}\text { Ögretim } \\
\text { Temsil Formu (ÖTF) }\end{array}$ \\
\hline Öğretim Anlayışı & $\mathrm{x}$ & $\mathrm{x}$ \\
Program Bilgisi & & $\mathrm{x}$ \\
Öğrenciyi Anlama Bilgisi & & $\mathrm{x}$ \\
Strateji, Yöntem ve Teknik Bilgisi & & $\mathrm{x}$ \\
Değerlendirme Bilgisi & & \\
\hline
\end{tabular}

Fen Öğretimi Uyum Testi (FÖUT). FÖUT'un hazırlanmasında ilk olarak alan yazında PAB yapısını çoktan seçmeli test tekniğiyle ölçmeyi amaçlayan çalışmalar incelenmiştir (Carlson, 1990; Cobern ve diğ., 2013; Kromrey ve Renfrow, 1991; Park, Suh ve Seo, 2017; Rohaan, Taconis ve Jochems, 2009; Schuster ve diğ. 2007). Bu kapsamda Schuster ve diğerleri'nin (2007) "The Multiple-Choice Question (MCQ)" adını verdikleri test geliştirme çalışmaları örnek model olarak tercih edilmiştir. Bu modeldeki test soruları alışılagelmiş geleneksel çoktan seçmeli testler gibi bir doğru cevap ve bunun yanında çeldiriciler olarak adlandırılan birkaç yanlış düşünceyi içermemektedir. Bunun yerine MCQ testi, fene ilişkin bir bilginin öğretmen tarafından bilinen bir ürün olarak sunulmasından, sorgulama yoluyla bir fen öğrenme oluşumunu ifade eden çoktan seçmeli 
maddelerden oluşmaktadır. Ayrıca testteki maddelerin her bir seçeneği dört temel düşünce formunu içermektedir. Bunlar: doğrudan bilgilendirme, doğrudan etkileşim, rehberlikli sorgulama ve keşfetmedir. Bu araştırma için hazırlanan fen öğretim uyumu testinin her bir maddesi üç bölümden oluşmaktadır. Birinci bölüm, vücudumuzdaki sistemler konularına ilişkin örnek bir öğretim kesitini içeren problem senaryosudur. İkinci bölüm, problem senaryosunun çözümünde hangi tür öğretimin etkili olacağına ilişkin dört adet seçeneği içermektedir. Üçüncü bölüm ise ikinci bölümde seçilen öğretim yaklaşımının neden tercih edildiğine ilişkin soruyu içermektedir. Sinir, endokrin, dolaşım, solunum, sindirim ve boşaltım sistemleri konularını içeren toplam altı fen öğretim uyumu test maddesi hazırlanmıştır. Bu testten en yüksek 24 puan, en düşük 6 puan alınabilmektedir. Fen öğretim uyum testi pilot çalışması için fen bilgisi öğretmenliği lisans programında öğrenim gören 4. sınıf öğrencilerinden 112 öğrenciye bu test uygulanmıștır. Uygulama sonucu testten alınan ortalama puanın 17.24, standart sapmanın 4.18 olduğu görülmüşsür. Bu uygulama sonucunda ölçeğin iç tutarlılık katsayısı ( $\alpha$ ) .68 olarak hesaplanmıştır. Ayrıca ortaokullarda görevli 24 fen bilimleri öğretmenine mail yoluyla ulaşılarak üçer ay arayla iki defa uygulanan testin, test tekrar test güvenirliği sonuçlarına göre her iki uygulamanın puanları arasında orta düzeyde bir korelasyon ilişkisi bulunmuştur $(r=.61, p<.05)$. Bu araştırmada kullanılan fen öğretim uyumu test maddelerinden bir örnek aşağıda Şekil 4'te verilmiştir.

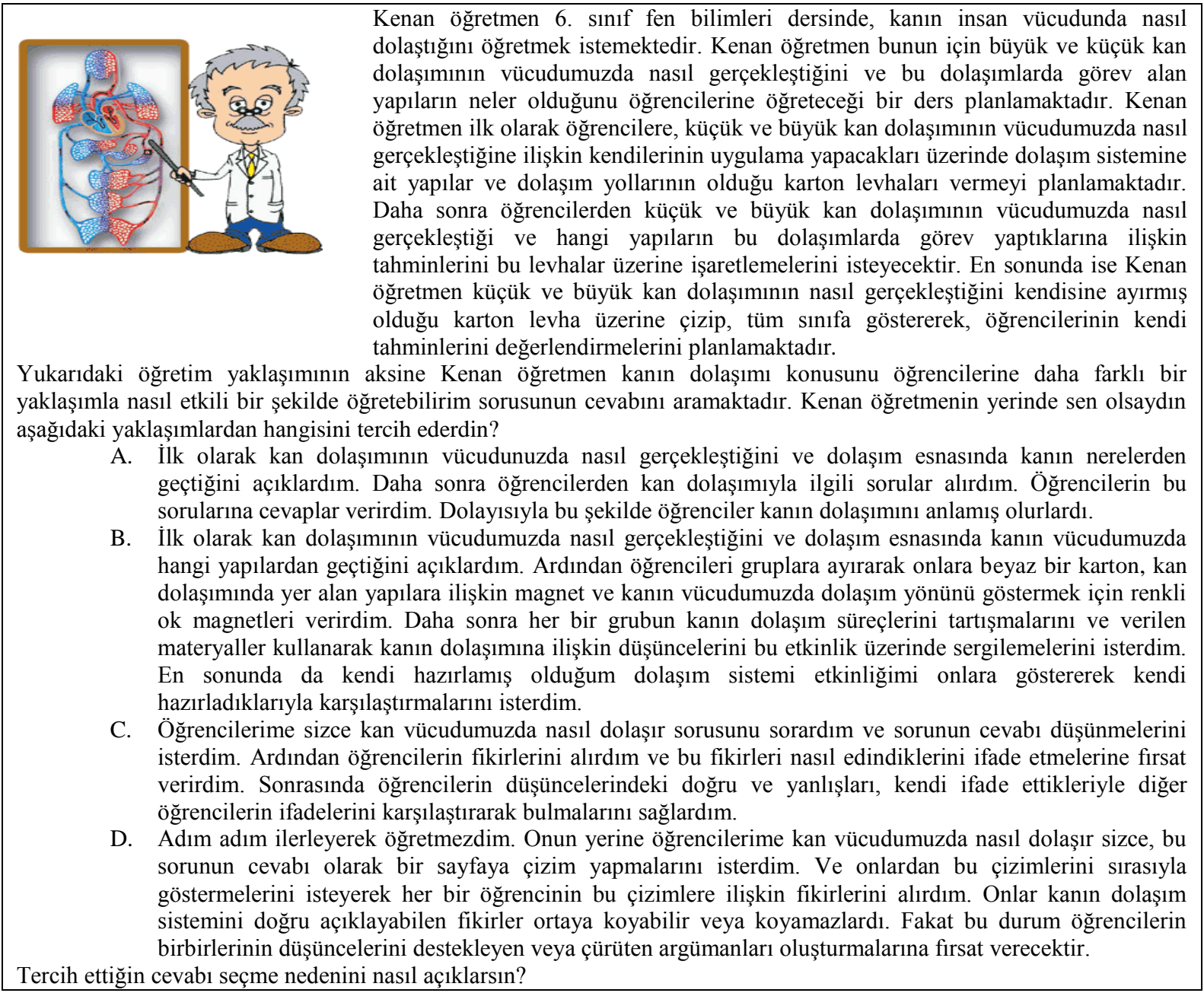

Şekil 4. Fen Öğretim Uyum Testi Örnek Maddesi.

Ögrretim Temsil Formu (ÖTF). ÖTF, Loughran'1n 2004 yılında fen bilimleri öğretmenlerinin özel bir fen konusunda PAB yapılarını belirlemek amacıyla geliştirilmiştir. Alan yazın incelendiğinde, ÖTF’nin son yıllarda $\mathrm{PAB}$ alanında çalışan araştırmacılar tarafından en çok kullanılan veri toplama tekniklerden birisi olduğu görülmektedir (Bertram ve Loughran, 2012; Hume ve Berry, 2011; Loughran ve di ̆. ., 2004; Nilsson ve Loughran, 2012; Rollnick ve diğ., 2008; Williams, Eames, Hume ve Lockley, 2012). ÖTF bir fen konusuna ilişkin öğrenme ve öğretim anlayışının sorgulanması esasına dayandığından, fen bilimleri öğretmen adaylarının eğitiminde kullanılabilecek önemli bir araç olarak görülmektedir (Abel, 2007; Loughran ve diğ., 2004; Loughran ve diğ., 2006). ÖTF, sekiz basamaklı bir soru yapısı ve her soru karşısında öğretmen adayının o soruya ilişkin var olan temel fikirlerini yazacağı boş alanlar şeklinde tasarlanmıştır. Örnek maddeler Tablo 4 'te gösterilmiştir. $\mathrm{Bu}$ araşıımada, fen bilimleri öğretmen adayları altı konu alanı içeriğinde (sinir, endokrin, dolaşım, solunum, 
sindirim, boşaltım) hem uygulama öncesi hem de uygulama sonrası fikirlerini PAB içerik temsil formuna belirtmişlerdir.

Tablo 4

ÖTF Örnek Soruları

\begin{tabular}{|c|c|c|}
\hline Konu & Fikir A & Fikir B \\
\hline Bu konuya ilişkin öğrencilerinin neyi öğrenmelerini amaçlamaktasın? & & \\
\hline Bu konuya ilişkin başka ne bilmektesin? (Öğrencilerinin henüz bilmesini istemediğin fikirler) & & \\
\hline
\end{tabular}

\section{Veri Analizi}

$\mathrm{Bu}$ araştırmada nicel ve nitel veri toplama tekniklerinin her ikiside yer aldığından eş zamanlı olarak nicel ve nitel analiz tekniklerinin kullanılması gerekmektedir. Bu bağlamda Onwueegbuzie ve Teddlie'nin (2003), her iki veri türünün analiz sürecini içeren modeli bu araştırma için tercih edilmiştir. $\mathrm{Bu}$ araştırmanın veri analizi için tercih edilen iki aşama şunlardır:

Verilerin azaltılması. Nicel veri betimleyici istatistik kullanılarak analiz edilir, nitel veriler betimleyici tema kullanılarak kategorileştirilir.

Verilerin sergilenmesi. Her iki kaynaktan veri grafiksel ve matriksel görsel kullanılarak organize edilir ve sunulur.

Fen Öğretim Uyum Testi (FÖUT) Analizi. Deney ve kontrol grubu öğretmen adaylarına deneysel işlem öncesi ve sonrası uygulanan $F O ̈ U T$ ile elde edilen verilerin analizinde iki yol izlenmiştir. Birincisi her iki grupta yer alan öğretmen adaylarının farklı içerik konularının öğretimi bakımından seçmiş oldukları yaklaşıma göre kişi sayısı ve yüzdelik dağılımları hesaplanmıştır. İkinci aşamada ise deney ve kontrol grubu öğretmen adaylarının, FÖUT'un her maddesinin altında seçtikleri yaklaşıma ilişkin gerekçeleri, Magnusson, Krajcik ve Borko'nun (1999) dokuz boyutlu fen öğretim uyumu kategorilerine göre betimlenmiştir. Araştırma verilerinin analiz güvenirliğini sağlamak amacıyla başka uzman analizcilerle karşılıklı kodlama ve puanlama yapılması önemlidir. Birden fazla araştırmacının veri analizinde birlikte çalıştığı durumlarda, kodlama güvenirliğine ilişkin bir çalışma yapmak gerekir. Bu durumda araştırmacılar, aynı veri setlerini kodlar ve ortaya çıkan kodlama benzerlikleri ve farklılıkları sayısal olarak karşılaştırılıp bir kodlama yüzdesine ulaşılır. Bu tür çalışmalarda en az \% 70 düzeyinde bir güvenirlik yüzdesine ulaşmak gerekir (Yıldırım ve Simsek, 2011). Miles ve Huberman (1994), nitel verilerin kodlanmasında araştırmacılar için "Görüş birliği/(Görüs birliği + Görǚs ayrıllğı) x 100" formülü kullanılarak kodlayıcılar arasındaki tutarlılı̆ının hesaplanacağını ifade etmişlerdir. Bu araştırmada verilerin analiz güvenirliğini sağlamak amacıyla araştırmacılar ve başka bir fen öğretmen adayı eğitimcisi karşılıklı olarak 24 adayın FÖUT'daki açık uçlu soruya vermiş oldukları yanıtları Magnusson, Krajcik ve Borko (1999) tarafından oluşturulan kategoriler altında sınıflandırılmıştır. $\mathrm{Bu}$ değerlendirmeler sonucunda araştırmacılardan birisi ile fen öğretmen adayı eğitimcisinin kodlamaları arasındaki tutarlılık oranı $\% 78$ olarak hesaplanmıştır. Aynı şekilde diğer araştırmacı ve fen öğretmen adayı eğitimcisi arasındaki kodlama tutarlılık oranı ise \% 72 olduğu görülmüştür. Bu oranlar verilerin analizinde güvenilirlik bakımından yeterli kabul edilmektedir.

Öğretim Temsil Formu (ÖTF) Analizi. Deney ve kontrol grubu öğretmen adayları uygulama öncesi ve sonrası altı farklı öğretim konusunda ÖTF'de yer alan sekiz açık uçlu soruyu yanıtlamışlardır. Öğretmen adaylarının bu sorulara vermiş oldukları yanıtları analiz etmek amacıyla araştırmacılar tarafindan bir puanlama ölçeği (rubrik) hazırlanmıştır. Bu ölçek, nitel verileri sayısal hale getirmek için her açık uçlu soruya karşılık gelecek ideal fikirleri içermektedir. Bu puanlama ölçeğinin hazırlanmasında, Saeli, Perrenet ve Jochems'in (2012) öğretim temsil formu değerlendirme ölçütlerini ele aldıkları çalışma temel alınmıştır. Araştırmacılar formu değerlendirmede kullanılacak ölçütleri, deneyimli ve iyi eğitimli öğretmen fikirleri alarak belirlemişlerdir. Bu araştırmada da ÖTF analizlerinde kullanılmak üzere ideal fikir kriterleri yazılırken dört deneyimli fen bilimleri öğretmeni ve iki fen öğretmen adayı eğitimcisinden destek alınmıştır. Araştırmacı tarafından yazılan ideal fikirler deneyimli öğretmenler ve öğretim üyeleriyle toplam dört oturumluk bir müzakerenin ardından belirlenmiştir. $\mathrm{Bu}$ kapsamda vücudumuzdaki sistemler konularına ilişkin altı ayrı ÖTF puanlama ölçeği hazırlanmıştır. Saeli ve diğerleri (2012) bu veri analizlerinin nitel doğası bakımından öğretmen adaylarının ÖTF'ye vermiş oldukları cevapların, ideal fikirleri tam anlamıla karşılayamayacağını fakat benzer ifadelerin pozitif olarak değerlendirilmesi gerektiğini ifade etmişlerdir. ÖTF'nin değerlendirilmesi için dört seviyeli bir puanlama hazırlanmıştır. Bunlar: eğer hiçbir cevap vermemişse veya geçersiz cevap ise "Boş", eğer ideal fikirlerin 1/3'nü karşllıyorsa "Zaylf", eğer ideal fikirlerin 2/3'nü karşıllyorsa "Orta" ve eğer ideal fikirlerin tamamını karşıllyorsa "Gelişmiş (Yüksek)" olarak belirlenmiştir. Bu araştırmada deney ve kontrol grubu öğretmen adaylarının uygulama öncesi ve sonrası tüm ÖTF’leri bu ölçütlere bağlı olarak değerlendirilmiştir. 
ÖTF formuna ilişkin hazırlanan örnek puanlama ölçütlerinden bir bölüm Tablo 5'te gösterilmiştir. Verilerin analiz güvenirliğini sağlamak amacıyla uygulama sonrası 26 adet ÖTF, bir araştırmacı ve öğretim üyesi tarafından ayrı ayrı puanlanmıştır. Elde edilen bu puanların karşılaştırılması sonucu, araştırmacı ile öğretim üyesi arasındaki ortalama tutarlılığın \% 74 olduğu görülmüştür. Bu değer ÖTF'nin analizinde güvenirliğin sağlandığını göstermektedir.

Tablo 5

Dolaşım Sistemi Konusunda Öğretim Temsil Formu (ÖTF) 2. ve 4. Soruları İçin Değerlendirme Ölçütleri

\begin{tabular}{|c|c|}
\hline Bu fikri bilmek öğrenciler için niçin önemlidir? & Bu fikri öğretmekle ilgili zorluklar/sınırlılıklar nedir? \\
\hline 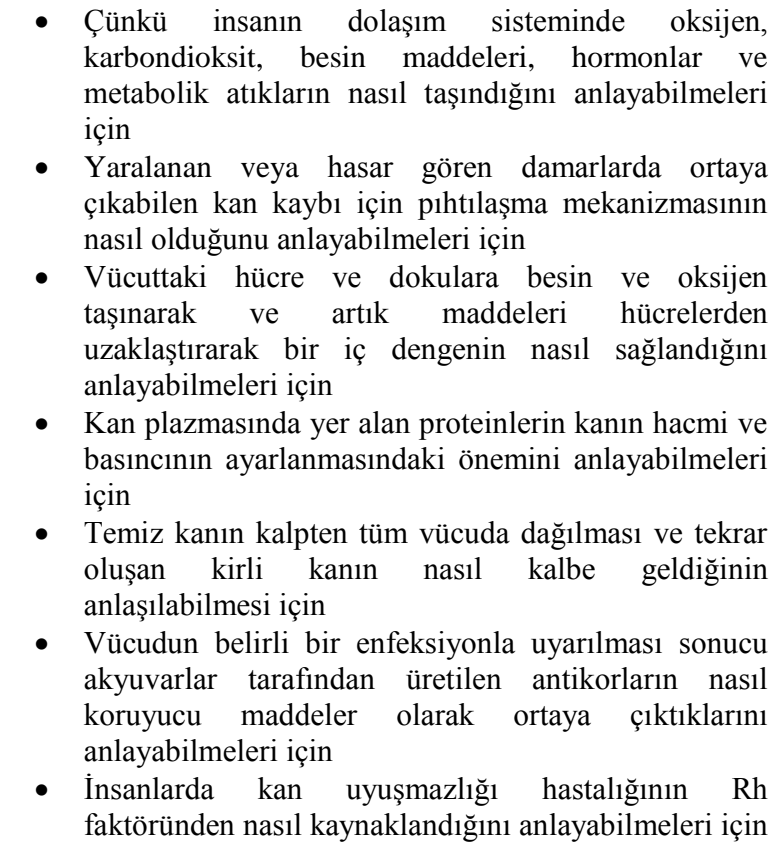 & $\begin{array}{ll}\text { - } & \text { Kan hücrelerinin fonksiyonları birbirine } \\
& \text { karıştırılabilir } \\
\text { - } & \text { Büyük ve küçük kan dolaşımının aşamaları birbirine } \\
& \text { karıştırılabilir. } \\
\text { - } & \text { Kan damarlarının işlevlerini karıştırabilirler } \\
\text { - } & \text { Kalbin yapısında bulunan kapakçık ve kulakçıklar } \\
& \text { ilişkin kavram yanılgıları oluşabilir. } \\
\text { - } & \text { Kan basıncının neden olduğu küçük ve büyük } \\
\text { - } & \text { tansiyonun nasıl oluştuğunu anlamakta } \\
& \text { zorlanabilirler } \\
\text { - Kanın pıhtılaşması olayını anlamada zorlanabilirler }\end{array}$ \\
\hline
\end{tabular}

\section{Bulgular}

Araştırmanın bu bölümünde, deney ve kontrol grubu öğretmen adaylarının fen öğretim uyumu ve PAB boyutlarına ilişkin uygulama öncesi ve sonrası durumları tablo ve grafikler halinde sunulmuştur.

\section{Deney ve Kontrol Grubu Öğretmen Adaylarının Uygulama Öncesi ve Sonrası FÖUT’daki Durumlarına İlişkin Analiz Bulguları}

Deney ve kontrol gruplarının uygulama öncesi ve sonrası FÖUT'a verdikleri cevapların, frekans ve yüzdelerine ilişkin analiz bulguları Tablo 6 ve 7'de sunulmuştur. Yine öğretmen adaylarının fen öğretim yaklaşımlarının gerekçelerine ilişkin analiz bulguları da Tablo 8 ve 9'da sunulmuştur.

Tablo 6'daki bulgular, deney ve kontrol grubu öğretmen adaylarının uygulama öncesinde vücudumuzdaki sistemler konularına ilişkin öğretim yaklaşımı tercihlerini göstermektedir. Tablo 6 incelendiğinde deney grubu öğretmen adaylarının uygulama öncesi öğretim yaklaşımı tercihlerinin, tüm konularda \% 43'lük ortalama ile en yüksek doğrudan bilgilendirme boyutunda olduğu tespit edilmiştir. Deney grubu öğretmen adaylarının uygulama öncesi en düşük öğretim yaklaşımı tercihlerinin ise \% 10'luk ortalama ile keşfederek öğrenme boyutunda olduğu tespit edilmiştir. Kontrol grubunda yer alan fen bilimleri öğretmen adaylarının uygulama öncesi öğretim yaklaşımı tercihlerinin ise \% 46'lık ortalama ile en yüksek doğrudan bilgilendirme boyutunda, en düşük öğretim yaklaşımı tercihlerinin ise \% 11'lik ortalama ile keşfederek ögrenme boyutunda olduğu tespit edilmiştir. Bu bulgular hem deney hem de kontrol grubu öğretmen adaylarının uygulama öncesinde konuların öğretimine ilişkin tercih ettikleri yaklaşımların büyük oranda bilginin öğrencilere bilinen bir ürün olarak kendileri tarafından sunulması şeklinde bir anlayışa sahip olduklarını göstermektedir. 
Tablo 6

Deney ve Kontrol Grubu Öğretmen Adaylarının Uygulama Öncesi FÖOT Analiz Bulguları

\begin{tabular}{|c|c|c|c|c|c|c|c|c|c|}
\hline \multirow[b]{3}{*}{ Konu İçeriği } & \multirow[b]{3}{*}{$\begin{array}{l}\mathrm{f} \\
\%\end{array}$} & \multicolumn{4}{|c|}{ Deney Grubu } & \multicolumn{4}{|c|}{ Kontrol Grubu } \\
\hline & & \multicolumn{2}{|c|}{$\begin{array}{l}\text { Bilinen Bir Ürün } \\
\text { Olarak Sunulan Fen }\end{array}$} & \multicolumn{2}{|c|}{$\begin{array}{l}\text { Sorgulama Yoluyla } \\
\text { Ögrrenilen Fen }\end{array}$} & \multicolumn{2}{|c|}{$\begin{array}{l}\text { Bilinen Bir Ürün } \\
\text { Olarak Sunulan Fen }\end{array}$} & \multicolumn{2}{|c|}{$\begin{array}{c}\text { Sorgulama Yoluyla } \\
\text { Öğrenilen Fen }\end{array}$} \\
\hline & & 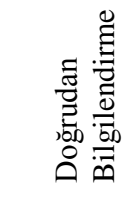 & 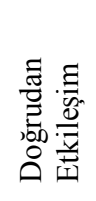 & 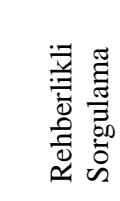 & 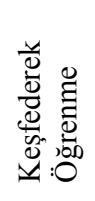 & 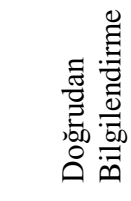 & 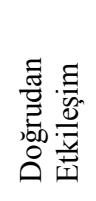 & 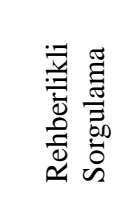 & 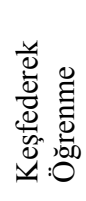 \\
\hline \multirow{2}{*}{ Sinir S. } & $f$ & 10 & 11 & 6 & 3 & 13 & 8 & 4 & 5 \\
\hline & $\%$ & 33.3 & 36.7 & 20 & 10 & 43.3 & 26.7 & 13.3 & 16.7 \\
\hline \multirow{2}{*}{ Endokrin S. } & $f$ & 14 & 9 & 4 & 3 & 15 & 7 & 5 & 3 \\
\hline & $\%$ & 46.7 & 30 & 13.3 & 10 & 50 & 23.3 & 16.7 & 10 \\
\hline \multirow{2}{*}{ Dolaşım S. } & $f$ & 14 & 8 & 5 & 3 & 15 & 8 & 4 & 3 \\
\hline & $\%$ & 46.7 & 26.7 & 16.7 & 10 & 50 & 26.7 & 13.3 & 10 \\
\hline \multirow{2}{*}{ Solunum S. } & $f$ & 12 & 9 & 5 & 4 & 14 & 8 & 5 & 3 \\
\hline & $\%$ & 40 & 30 & 16.7 & 13.3 & 46.7 & 26.7 & 16,7 & 10 \\
\hline \multirow{2}{*}{ Sindirim S. } & $f$ & 13 & 9 & 5 & 3 & 14 & 8 & 5 & 3 \\
\hline & $\%$ & 43.3 & 30 & 16.7 & 10 & 46.7 & 26.7 & 16.7 & 10 \\
\hline \multirow{2}{*}{ Boşaltım S. } & $f$ & 15 & 8 & 5 & 2 & 12 & 11 & 5 & 2 \\
\hline & $\%$ & 50 & 26.7 & 16.7 & 6.7 & 40 & 36.7 & 16.7 & 6.7 \\
\hline Ort. & $\%$ & 43 & 30 & 17 & 10 & 46 & 28 & 15 & 11 \\
\hline
\end{tabular}

Tablo 7

Deney ve Kontrol Grubu Öğretmen Adaylarının Uygulama Sonrası FÖOT Analiz Bulguları

\begin{tabular}{|c|c|c|c|c|c|c|c|c|c|}
\hline \multirow[b]{3}{*}{ Konu İçeriği } & \multirow[b]{3}{*}{$\begin{array}{l}f \\
\%\end{array}$} & \multicolumn{4}{|c|}{ Deney Grubu } & \multicolumn{4}{|c|}{ Kontrol Grubu } \\
\hline & & \multicolumn{2}{|c|}{$\begin{array}{l}\text { Bilinen bir ürün } \\
\text { olarak sunulan fen }\end{array}$} & \multicolumn{2}{|c|}{$\begin{array}{c}\text { Sorgulama yoluyla } \\
\text { öğrenilen fen }\end{array}$} & \multicolumn{2}{|c|}{$\begin{array}{l}\text { Bilinen bir ürün } \\
\text { olarak sunulan fen }\end{array}$} & \multicolumn{2}{|c|}{$\begin{array}{c}\text { Sorgulama yoluyla } \\
\text { öğrenilen fen }\end{array}$} \\
\hline & & 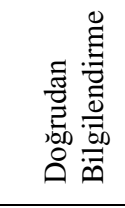 & 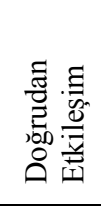 & 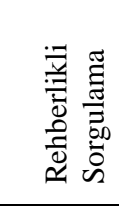 & 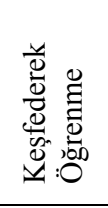 & 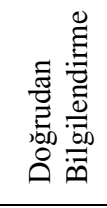 & 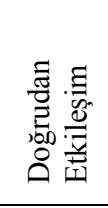 & 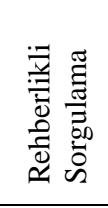 & 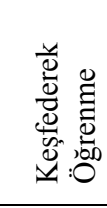 \\
\hline \multirow{2}{*}{ Sinir S. } & $f$ & 3 & 8 & 12 & 7 & 4 & 15 & 5 & 6 \\
\hline & $\%$ & 10 & 26.7 & 40 & 23.3 & 13.3 & 50 & 16,7 & 20 \\
\hline \multirow{2}{*}{ Endokrin S. } & $f$ & 4 & 6 & 12 & 8 & 3 & 14 & 8 & 5 \\
\hline & $\%$ & 13.3 & 20 & 40 & 26.7 & 10 & 46.7 & 26.7 & 16,7 \\
\hline \multirow{2}{*}{ Dolaşım S. } & $f$ & 4 & 9 & 8 & 9 & 10 & 9 & 5 & 6 \\
\hline & $\%$ & 13.3 & 30 & 26.7 & 30 & 33.3 & 30 & 16.7 & 20 \\
\hline \multirow{2}{*}{ Solunum S. } & $f$ & 3 & 10 & 7 & 10 & 9 & 10 & 7 & 4 \\
\hline & $\%$ & 10 & 33.3 & 23.3 & 33.3 & 30 & 33.3 & 23.3 & 13.3 \\
\hline \multirow{2}{*}{ Sindirim S. } & $f$ & 3 & 9 & 9 & 9 & 6 & 13 & 7 & 4 \\
\hline & $\%$ & 10 & 30 & 30 & 30 & 20 & 43.3 & 23.3 & 13.3 \\
\hline \multirow{2}{*}{ Boşaltım S. } & $f$ & 4 & 10 & 8 & 8 & 8 & 8 & 9 & 5 \\
\hline & $\%$ & 13.3 & 33.3 & 26.7 & 26.7 & 26.7 & 26.7 & 30 & 16.7 \\
\hline Ort. & $\%$ & 12 & 29 & 31 & 28 & 22 & 38 & 23 & 17 \\
\hline
\end{tabular}

Tablo 7'deki bulgular, deney ve kontrol grubundaki öğretmen adaylarının uygulama sonrası vücudumuzdaki sistemler konularına ilişkin öğretim yaklaşımı tercihlerini göstermektedir. Bu bulgulara göre uygulama sonrasında deney grubu öğretmen adaylarının öğretim tercihlerinin, konuların tamamında ortalama \% 31 'lik oran ile en yüksek rehberlikli sorgulama boyutunda olduğu tespit edilmiştir. Deney grubu öğretmen adaylarının uygulama sonrası en düşük öğretim tercihlerinin ise ortalama \% 12'lik oran ile doğrudan bilgilendirme boyutunda olduğu tespit edilmiştir. Kontrol grubu öğretmen adaylarının uygulama sonrası öğretim tercihlerinin ise ortalama \% 38'lik oran ile en yüksek doğrudan etkileşim, en düşük öğretim tercihlerinin ise \% 17‘lik ortalama bir oranla keşfederek öğrenme boyutunda olduğu görülmüş̧ür. Bu bulgular uygulama sonrasında deney grubunda yer alan öğretmen adaylarının \% 59'unun, öğrencilerin fendeki bilgiyi sorgulama yoluyla öğrenmesi yönünde bir öğretim anlayışını tercih ettiklerini göstermektedir. Bunun yanında kontrol grubundaki fen bilimleri öğretmen adaylarının ise uygulama sonrası \% 60'lık bir oranla, öğrencilere bilginin bilinen bir ürün olarak sunulması yönünde bir fen öğretim anlayışına yine sahip olduklarını göstermektedir. Tablo 6 ve Tablo 7'deki 
deney ve kontrol gruplarında yer alan öğretmen adaylarının fen bilimlerindeki öğretim anlayışı tercihleri incelendiğinde, uygulama sonrasında deney grubunda yer alan adayların kontrol grubu öğretmen adaylarına göre, fen bilimlerinde bilgiyi öğrencilerin sorgulama yoluyla öğrenmesi gerektiği yönünde bir öğretim anlayışını daha fazla benimsediklerini ortaya koymaktadır.

Tablo 8

Deney ve Kontrol Grubu Öğretmen Adaylarının Uygulama Öncesi Fen Öğretim Uyumu Gerekçelerine İlişkin Analiz Bulgularl

\begin{tabular}{|c|c|c|c|c|c|c|c|c|c|c|c|c|c|c|}
\hline \multirow{3}{*}{$\begin{array}{l}\text { Fen Öğretimi } \\
\text { Uyum Modeli }\end{array}$} & \multicolumn{7}{|c|}{ Deney Grubu } & \multicolumn{7}{|c|}{ Kontrol Grubu } \\
\hline & 足. & 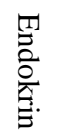 & 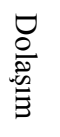 & $\frac{\mathscr{\mathscr { O }}}{\stackrel{\Xi}{\Xi}}$ & $\begin{array}{l}\mathscr{n} \\
: \\
:\end{array}$ & 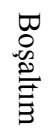 & 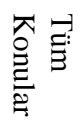 & : & $\begin{array}{l}\frac{T}{\mathrm{O}} \\
\frac{0}{0} \\
\frac{0}{\mathrm{O}}\end{array}$ & 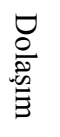 & $\begin{array}{l}\mathscr{2} \\
\stackrel{\Xi}{\Xi} \\
\vdots\end{array}$ & 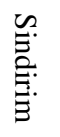 & 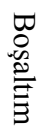 & 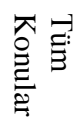 \\
\hline & $f$ & $f$ & $f$ & $f$ & $f$ & $f$ & $\%$ & $f$ & $f$ & $f$ & $f$ & $f$ & $f$ & $\%$ \\
\hline Proje Yoluyla Bilim & 1 & 2 & 1 & 2 & 1 & 2 & 5 & 1 & 1 & 1 & 2 & 2 & 1 & 4 \\
\hline Bilimsel Süreç Temelli & 4 & 2 & 1 & 1 & 1 & 2 & 6 & 2 & 2 & 2 & 3 & 1 & 2 & 7 \\
\hline Rehberlikli Sorgulama & 3 & 1 & 3 & 2 & 3 & 2 & 8 & 2 & 1 & 2 & 2 & 1 & 1 & 5 \\
\hline Yaparak Deneyimle & 3 & 2 & 3 & 1 & 4 & 1 & 8 & 4 & 3 & 3 & 1 & 2 & 2 & 8 \\
\hline Keşfederek Öğrenme & 3 & 2 & 2 & 1 & 1 & 2 & 6 & 4 & 2 & 1 & 2 & 1 & 4 & 8 \\
\hline Sorgulama & 1 & 2 & 1 & 3 & 2 & 3 & 7 & 2 & 1 & 2 & 3 & 1 & 2 & 6 \\
\hline Kavramsal Değişim & 1 & 1 & 2 & 2 & 2 & 1 & 5 & 1 & 3 & 1 & 2 & 2 & 0 & 5 \\
\hline Bilimsel Katılık & 2 & 3 & 3 & 2 & 1 & 2 & 7 & 2 & 1 & 2 & 0 & 2 & 2 & 5 \\
\hline Doğrudan Bilgilendirme & 12 & 15 & 14 & 16 & 15 & 15 & 48 & 12 & 16 & 16 & 15 & 18 & 16 & 52 \\
\hline
\end{tabular}

Deney ve Kontrol grubu öğretmen adaylarının uygulama öncesi öğretim yaklaşımı gerekçelerinin analiz bulguları Tablo 8'de gösterilmiştir. Bu bulgulara göre deney grubundaki öğretmen adaylarının tercih ettikleri öğretim yaklaşımına ilişkin gerekçeleri uygulama öncesinde \% 48'lik bir oran ile en yüksek doğrudan bilgilendirme boyutu altında toplandığını göstermektedir. Deney grubundaki öğretmen adaylarının uygulama öncesi öğretim yaklaşımı tercih gerekçelerinin \% 5'lik en düşük oranda ise proje yoluyla ögrenme ve kavramsal değişime yönelik olduğu görülmektedir. Kontrol grubu öğretmen adaylarının öğretim yaklaşımı tercih gerekçelerinin ise uygulama öncesinde \% 52'lik oranla doğrudan bilgilendirme boyutunu öne çıkaran düşünceler etrafinda büyük oranda toplandığ göstermektedir. Yine kontrol grubu öğretmen adaylarının öğretim yaklaşımı tercih gerekçelerinin uygulama öncesinde \% 4'lük en düşük oranda proje yoluyla ögrenme boyutunu öne çıkaran düşünceler etrafinda yoğunlaştığı görülmüştür. Bu sonuçlar her iki uygulama grubundaki fen bilimleri öğretmen adaylarının öğretim yaklaşım tercih gerekçelerinin uygulama öncesinde benzerlik gösterdiğini ortaya koymuştur.

Tablo 9

Deney ve Kontrol Grubu Öğretmen Adaylarının Uygulama Sonrası Fen Öğretim Yaklaşımı Gerekçelerine İlişkin Analiz Bulgulart

\begin{tabular}{|c|c|c|c|c|c|c|c|c|c|c|c|c|c|c|}
\hline \multirow{3}{*}{ Fen Öğretimi Uyum Modeli } & \multicolumn{7}{|c|}{ Deney Grubu } & \multicolumn{7}{|c|}{ Kontrol Grubu } \\
\hline & 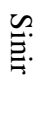 & 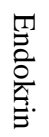 & 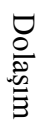 & 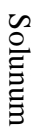 & $\begin{array}{l}\widetilde{\Xi} \\
\text { : } \\
\text { : }\end{array}$ & 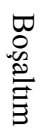 & 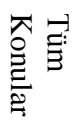 & 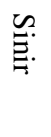 & 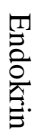 & 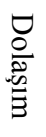 & 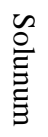 & $\begin{array}{l}\simeq \\
\text { : } \\
\text { : }\end{array}$ & 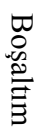 & ‡્ત \\
\hline & $f$ & $f$ & $f$ & $f$ & $f$ & $f$ & $\%$ & $f$ & $f$ & $f$ & $f$ & $f$ & $f$ & $\%$ \\
\hline Proje Yoluyla Bilim & 2 & 1 & 3 & 2 & 2 & 4 & 8 & 2 & 4 & 2 & 3 & 3 & 4 & 10 \\
\hline Bilimsel Süreç Temelli & 1 & 3 & 1 & 2 & 4 & 3 & 8 & 6 & 8 & 6 & 9 & 8 & 7 & 24 \\
\hline Rehberlikli Sorgulama & 6 & 6 & 5 & 5 & 3 & 6 & 17 & 2 & 0 & 4 & 1 & 3 & 2 & 7 \\
\hline Yaparak Deneyimleme & 2 & 2 & 1 & 1 & 5 & 2 & 7 & 5 & 3 & 1 & 3 & 3 & 3 & 10 \\
\hline Keşfedici Öğrenme & 7 & 7 & 7 & 8 & 8 & 7 & 24 & 2 & 2 & 3 & 3 & 2 & 1 & 7 \\
\hline Sorgulama & 9 & 7 & 8 & 7 & 6 & 5 & 23 & 2 & 1 & 2 & 1 & 2 & 3 & 6 \\
\hline Kavramsal Değiş̧im & 0 & 2 & 2 & 2 & 3 & 0 & 5 & 1 & 3 & 3 & 3 & 2 & 3 & 8 \\
\hline Bilimsel Katılık & 1 & 1 & 2 & 1 & 0 & 1 & 3 & 3 & 3 & 5 & 3 & 2 & 3 & 11 \\
\hline Doğrudan Bilgilendirme & 2 & 1 & 1 & 2 & 1 & 2 & 5 & 7 & 6 & 4 & 4 & 5 & 4 & 17 \\
\hline
\end{tabular}

Deney ve Kontrol grubu öğretmen adaylarının öğretim yaklaşımı tercih gerekçelerine ilişkin uygulama sonrası analiz bulguları Tablo 9'da sunulmuştur. Bu bulgulara göre deney grubundaki öğretmen adaylarının öğretim yaklaşımı tercih gerekçeleri uygulamanın sonrasında, \% 24'lük bir oran ile en yüksek keşfederek ögrrenmeye dayalı düşünceler etrafında toplandığını göstermektedir. Deney gurubundaki öğretmen adaylarının uygulama 
sonrası öğretim yaklaşımı tercih gerekçeleri ise \% 5 olarak en düşük oranda, bilimsel katılık boyutunu vurgulayan düşünceler etrafında şekillendiğini görülmüştür. Kontrol grubunun öğretim yaklaşımları tercih gerekçeleri uygulama sonrasında en yüksek orana \% 24 ile bilimsel süreç temelli boyutunu vurgulayan düşünceler etrafında toplandığını göstermiştir. Yine kontrol grubu öğretmen adaylarının öğretim yaklaşımı tercih gerekçelerinin uygulama sonrasında en düşük oranda \% 6 ile sorgulama yoluyla öğrenme boyutunu vurgulayan düşüncelerde toplandığı görülmektedir. Bu sonuçlar uygulama sonrasında her iki grupta yer alan öğretmen adaylarının öğretim yaklaşımı tercih gerekçelerinde önemli farklılıklar ortaya çıktığını göstermiştir. Deney grubundaki öğretmen adaylarının öğretim yaklaşımı tercih gerekçelerinin büyük oranda sorgulama ve keşfetmeye dayalı düşünceler etrafında şekillendiği, kontrol grubunda ise bilimsel süreçlere dayalı düşünceler etrafında yoğunlaştı̆̆ını ortaya koymaktadır.

\section{Deney ve Kontrol Grubu Öğretmen Adaylarının Öğretim Uyumu Değişimleri}

Tablo 8 ve Tablo 9'daki fen bilimleri öğretmen adaylarının öğretim yaklaşımı tercih gerekçelerine ilişkin analiz bulgularına bakıldığında, hem deney grubu hem de kontrol grubu öğretmen adaylarının gerekçelerinin uygulama öncesi ve sonrasında farklı kategoriler arasında dağılım gösterdiği belirlenmiştir. Uygulama öncesinde deney grubu öğretmen adaylarının \% 48'i öğretimi yaklaşımı tercih gerekçelerini, öğretmen tarafından bilgilendirme yapılması olarak ifade ederken, kontrol grubu öğretmen adaylarının da yine \% 52'sinin öğretim yaklaşımı tercihlerinin bilgilendirme yapılması olarak ifade etmişlerdir. Her iki gruptaki öğretmen adaylarının da uygulama öncesi anlayışları fen konularının öğretiminde, bilimsel bilginin sağlam bir kaynaktan alınması gerektiğine yöneliktir. Ayrıca uygulama öncesinde her iki gruptaki öğretmen adaylarının büyük çoğunluğu öğretmenin, öğrenen için doğrudan bilgiyi biçimlendiren bir role sahip olması gerektiğine vurgu yaptıkları görülmüştür. Deney ve kontrol grubundan öğretmen adaylarının bu düşüncelerini belirten örnek alıntılar aşağıda gösterilmiştir.

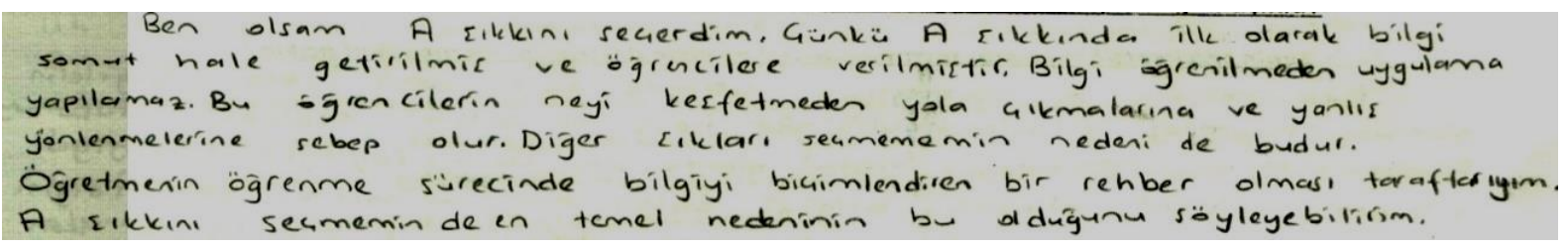

(Deney\#12)

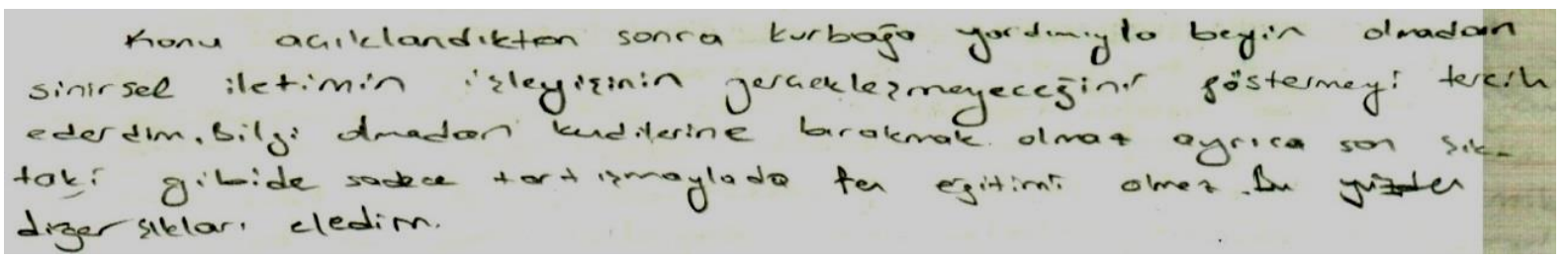

(Kontrol\#25)

Yukardaki açıklamalara bakıldığında her iki grupta yer alan öğretmen adayının da uygulama öncesinde öğretmen merkezli bir bilgi anlayışına sahip oldukları ve dahası bilginin hazır olarak öğretmen tarafından sunulmasının fen öğretim uyumu için gerekli olduğunu belirten bir anlayışı benimsediklerini göstermektedir. Uygulama sonrasında öğretmen adaylarının fen öğretim uyumu tercih gerekçeleri, uygulama öncesine göre önemli değişiklikler göstermiştir. Deney grubundaki öğretmen adaylarının uygulama öncesinde \% 7 olan sorgulamaya dayalı öğrenme gerekçesi uygulama sonrasında \% 23'lük bir orana ulaştığı görülmektedir. Ayrıca deney grubu öğretmen adaylarının rehberlikli sorgulama ve keşfederek öğrenme anlayışının da uygulama sonrasında, öncesine göre adaylar tarafından fen öğretim uyumu gerekçesi olarak daha yoğun bir şekilde ifade edildiği görülmüştür. Uygulama sonrasında deney grubundan bu durumu ifade eden örnek alıntı aşağıda sunulmuştur.

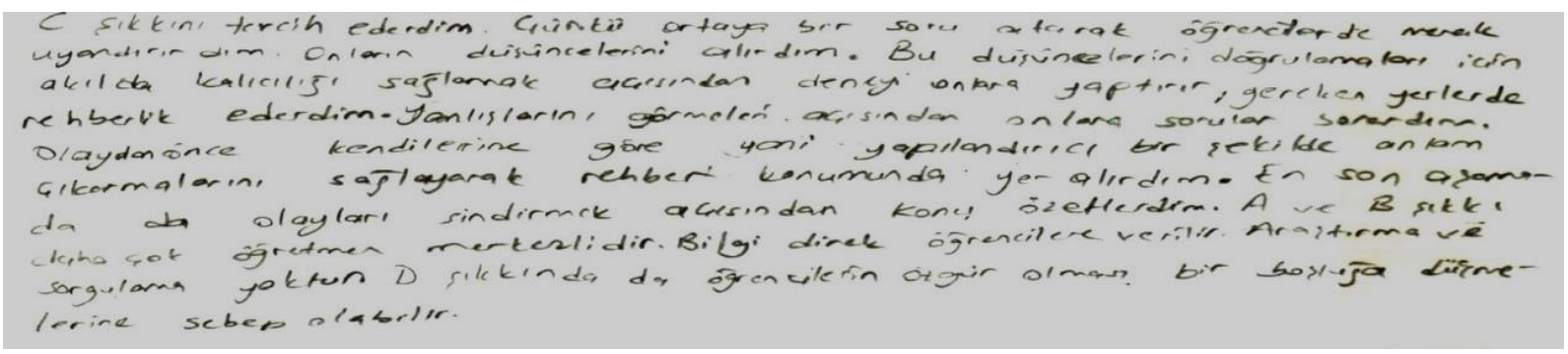

(Deney\#3) 
Yukarıdaki açıklamaya bakıldığında öğretmen adayının fen öğretiminde bilginin öğrenci tarafindan biçimlendirilmesi gerektiğine vurgu yaptığı görülmektedir. Öğretmen adayı öğrencinin bilimsel bilgiyi sorgulama yolları içerisinde yapılandırması ve öğretmenin bu süreçte sadece onları sorularıyla yönlendirecek bir rehber olarak görev yapması gerektiğinin altını çizmiştir. Ayrıca bilginin doğrudan öğretmen tarafindan verilmesinin öğrencilerin kendi bilişsel süreçlerini şsekillendirmede anlamlı bir deneyim olmadığını da vurgulamışıtır.

Kontrol grubu öğretmen adaylarının fen öğretim uyumu gerekçeleri ise, uygulama sonrasında \% 24'lük bir oranla bilimsel süreç becerilerinin geliştirilmesi üzerinde daha çok yoğunlaştığ 1 görülmüsşür. Bunun yanında kontrol grubu öğretmen adaylarının öğrenmenin sorgulama yoluyla gerçekleştirilmesine iliş̧kin öğretim uyumu gerekçelerinin uygulama sonrasında da çok az değişim gösterdiği belirlenmiştir. Öğretmen adaylarının görüşlerini gösteren bazı alıntılar aşağıda sunulmuştur.

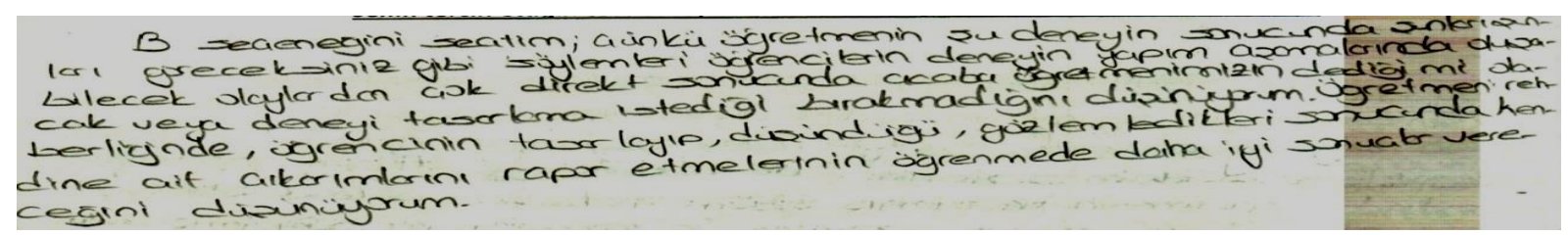

(Kontrol\#11)

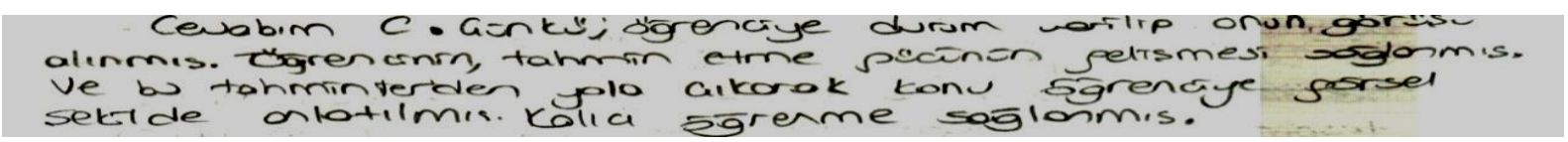

(Kontrol\#21)

Kontrol grubunda yer alan fen bilimleri öğretmen adaylarının uygulama sonrası öğretim yaklaşımı tercih gerekçelerine iliş̧in yukarıdaki açıklamalarına bakıldığında, öğrencilerin fen öğrenme sürecinde bilgiyi en temel kaynak olarak öğretmenden almaları ve bunun üzerine bilimsel süreç becerilerine yönelmeleri gerektiğine vurgu yaptıkları görülmektedir. Fen bilimleri öğretmen adaylarının öğretime ilişkin yaklaşımları her iki grupta da uygulama sonrasında önemli oranda farklılaştığı görülmüştür. Bu durum, deney grubundaki öğretmen adaylarının kontrol grubu öğretmen adaylarına kıyasla daha fazla oranda, öğrencinin bilgiyi yapılandırma sürecinin daha çok kendi sorgulamaları yoluyla gerçekleştirmesi gerektiğine yönelik bir anlayışın benimsendiği sonucunu ortaya koymuştur.

Deney ve kontrol grubu öğretmen adaylarının Uygulama Öncesi ve Sonrası ÖTF'deki Durumlarına İlişkin Analiz Bulguları

Bu bölümde, deney ve kontrol grubunda yer alan fen bilimleri öğretmen adaylarının uygulama öncesi ve sonrası ÖTF'edeki fikirlerinin düzeyine ilişkin analiz bulguları grafikler halinde sunulmuştur. Grafiklerde gösterilen değerler vücudumuzdaki sistemler konularda ÖTF'edeki her bir soruya karşllık öğretmen adaylarının üretmiş oldukları fikirlerin ortalama düzeylerini göstermektedir. Örneğin grafikte yer alan PABM1, ÖTF’edeki PAB'a ilişkin 1. maddeyi ifade etmektedir ve bu soruya ait bir düzey aralığında bulunan ortalama kişi sayısı vücudumuzdaki sistemler konu sayısı olan altıya bölünerek elde edilmiştir.

Grafik 1'de deney ve kontrol grubu öğretmen adaylarının uygulama öncesi vücudumuzdaki sistemler konularına ilişkin ÖTF’ye yazmış oldukları fikirlerin düzeyine ait bulgular gösterilmektedir. Bu bulgulara göre uygulama öncesinde formun alt boyutlarına ilişkin olarak öğrenci fikirlerinin en yoğun olarak boş/geçersiz ve zayıf düzeyde toplandığı görülmektedir. Bunun yanında yine uygulama öncesinde orta ve yüksek düzeyde fikir ürettikleri görülen öğretmen adaylarının sayısının çok düşük olduğu görülmektedir. Uygulama öncesinde deney grubu öğretmen adaylarının boş/geçersiz düzeyinde ortalama kişi sayısının yaklaşık 11; zayıf düzeyde 17; orta düzeyde 5 ve yüksek düzeyde ise 0 olduğu görülmektedir. Kontrol grubunda ise boş/geçersiz fikir üretme düzeyindeki ortalama kişi sayısının yaklaşık 10; zaylf düzeyde 19; orta düzeyde 4 ve yüksek düzeyde ise 0 kişinin olduğu görülmektedir. Bu bulgulara göre uygulama öncesinde her iki grupta yer alan öğretmen adaylarının fikir üretme düzeyleri bakımından benzer düzeylerde oldukları ve maalesef daha çok boş ve zayıf fikir düzeyinde kaldıkları anlaşılmaktadır. 


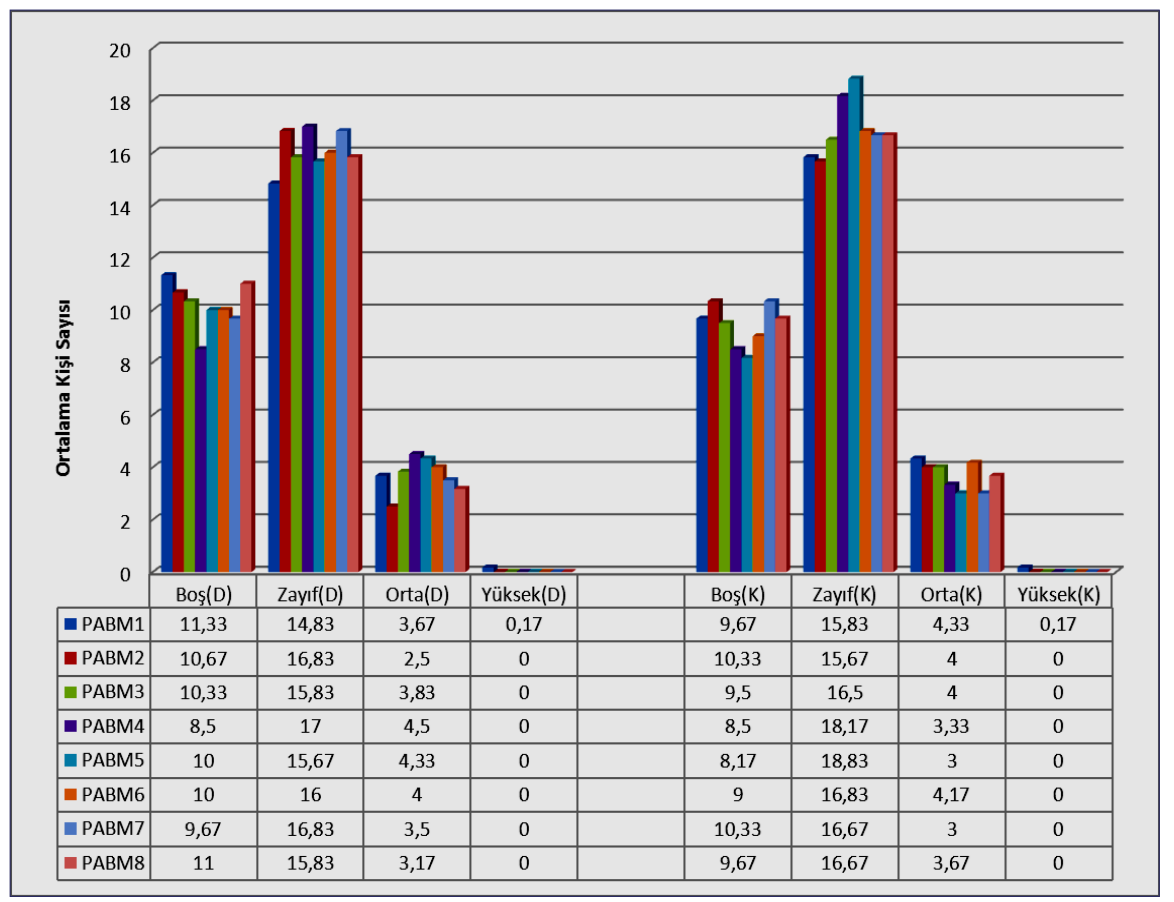

Grafik 1. Deney (D) ve Kontrol Grubu (K) Öğretmen Adaylarının Uygulama Öncesi ÖTF'edeki Fikirlerinin Düzeylerine İlişkin Analiz Sonuçları.

Grafik 2 deney ve kontrol grubu öğretmen adaylarının uygulama sonrası Vücudumuzdaki Sistemler konularına ilişkin ÖTF'ye yazmış oldukları fikirlerin düzeylerine ait bulguları göstermektedir. Bu bulgulara göre uygulama öncesinde forumdaki sorulara ilişkin olarak öğrenci fikirlerinin geçerliliğinde önemli farklılıklar olduğu görülmektedir. Uygulama sonrası deney grubu öğretmen adaylarının formdaki fikirlerinin boş/geçersiz düzeyde 0; zaylf düzeyde 4; orta düzeyde 17 ve yüksek (gelişmiş) düzeyde ise 12 ortalama kişiyle temsil edildiği görülmektedir. Kontrol grubundaki öğretmen adaylarının ise boş/geçersiz fikir düzeyinde 3; zayıf düzeyde 16; orta düzeyde 11 ve yüksek (gelişmiş) düzeyde 5 ortalama kişiyle temsil edildikleri görülmektedir. Bu sonuçlara göre özellikle uygulama sonrasında deney gurubu öğretmen adaylarının kontrol grubu öğretmen adaylarına göre fikir üretme düzeyi bakımından daha gelişmiş oldukları ve orta ve yüksek düzeyde fikir üretme bakımından daha fazla gelişim gösterdikleri anlaşılmaktadır.

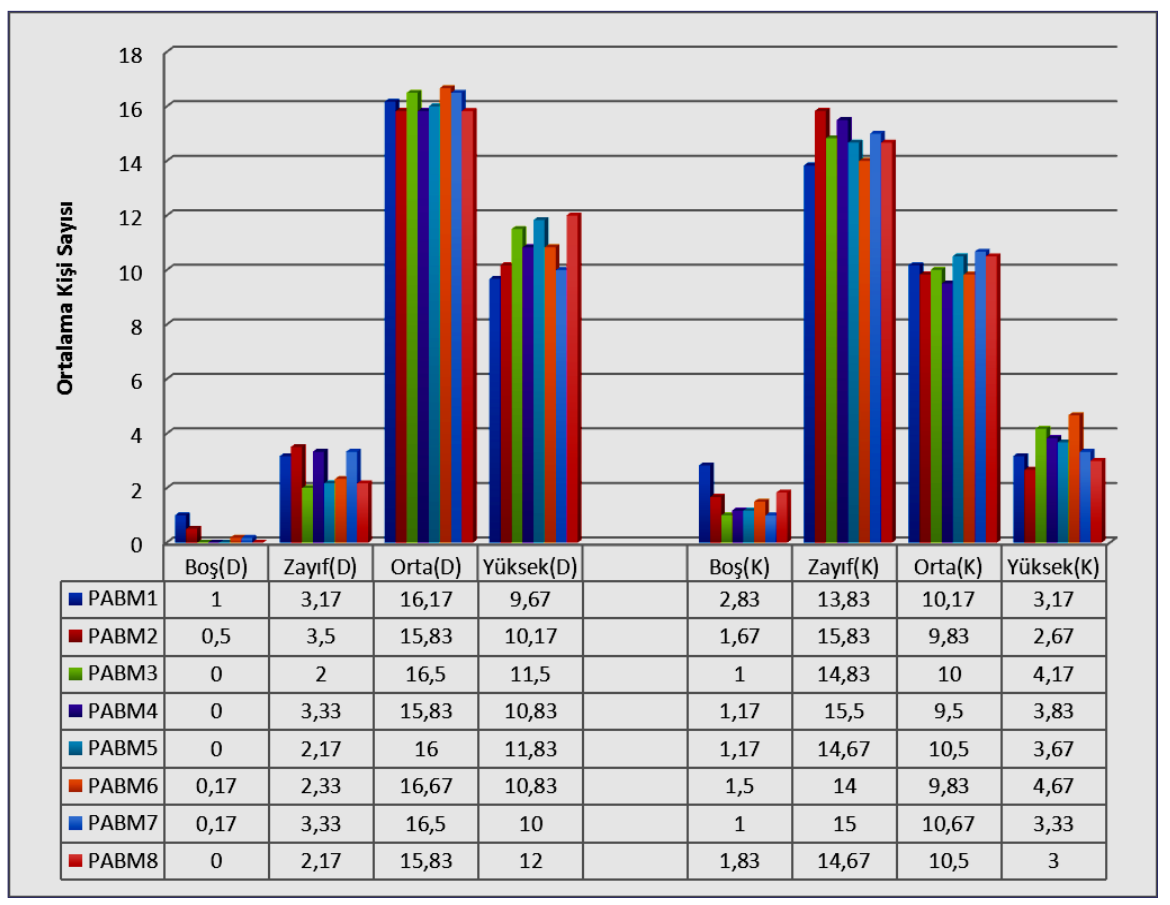

Grafik 2. Deney (D) ve Kontrol Grubu (K) Öğretmen Adaylarının Uygulama Sonrası ÖTF'deki Fikirlerinin Düzeylerine İlişkin Analiz Sonuçları. 


\section{Deney ve Kontrol Grubu Öğretmen Adaylarının ÖTF'deki Fikirlerinin Değişimi}

$\mathrm{Bu}$ bölümde deney ve kontrol grubu öğretmen adaylarının uygulama öncesi ve sonrası ÖTF'de yeralan düşüncelerine ilişkin değişimler yorumlanmıştır.

Deney ve Kontrol Grubu Öğretmen Adaylarının Program Bilgisi Değişimleri

- Sen bu konuda öğrencilerinin neyi öğrenmelerini amaçlamaktasın? (PABM1)

- Birinci soruya ait cevap sütununda ifade ettiğin fikirleri bilmek öğrenciler için niçin önemlidir? (PABM2)

- Birinci soruya ait cevap sütununda ifade ettiğin fikirlerlerle ilgili başka ne bilmektesin? (Henüz öğrencilerin bilmesini amaçlamadığın fikirler...) (PABM3)

Vücudumuzdaki sistemler konularına ilişkin olarak hem deney grubu hem de kontrol grubunda yer alan öğretmen adaylarının, uygulama öncesinde öğrencilerinin neyi öğrenmelerini amaçladıklarına ilişkin düşünce temsillerinin birbirine benzer içerikte olduğu ve ideal fikir üretmekte yetersiz kaldıkları görülmektedir. Uygulama öncesinde deney grubu öğretmen adaylarının, vücudumuzdaki sistemler konularında, öğrencilerin öğrenmesini amaçladıkları fikirler bakımından büyük oranda boş/geçersiz ve zayıf düzeyde toplandıkları görülmektedir. Aynı şekilde uygulama öncesinde kontrol grubu öğretmen adaylarının da öğrenme amaçlarına ilişkin olarak üretmiş oldukları fikirler bakımından büyük oranda yine boş/geçersiz ve zayıf düzeyde kaldıkları tespit edilmiştir. Uygulama öncesinde her iki gruptaki öğretmen adayları, konunun öğrenciler için niçin önemli olduğuna ilişsin üretmiş oldukları fikirler bakımından, yine büyük oranda boş/geçersiz ve zayıf düzeyde kaldıkları görülmüştür. Uygulama sonrasında deney grubu öğretmen adaylarının öğrencilerine neyi öğretmeyi amaçladıklarına ilişkin ideal ve geçerli fikir üretme düzeyi bakımından, uygulama öncesine göre boş/geçersiz ve zayıf düzeyde yer alan öğretmen adayı sayısında azalma olduğu, bunun yanında orta ve yüksek düzeyde yer alan öğretmen adayı sayısında ise artış olduğu görülmüştür. Yine uygulama sonrasında deney grubu öğretmen adaylarının öğrenciler için bu konunun niçin önemli olduğuna dair ifade ettikleri ideal fikirler bakımından önemli bir gelişim gösterdikleri anlaşılmaktadır. Kontrol grubu öğretmen adaylarının ise uygulama sonrası içerik konularına ilişkin olarak öğrencilerin öğrenmesini amaçladıkları fikirler bakımından boş/geçersiz düzeyinde kalan öğretmen adayı sayısında azalma olduğu, bu öğretmen adaylarının daha çok düşük ve orta düzeyde kaldıkları görülmektedir. Bunun yanında yine uygulama sonrasında kontrol grubu öğretmen adaylarını öğrenme amacına ilişkin olarak ifade ettikleri fikirler bakımından, yüksek düzeyde ideal fikir üreten öğretmen adayı sayısında önemli bir artışın olmadığı görülmektedir. Program bilgisine ilişkin olarak deney ve kontrol grubu öğretmen adaylarının uygulama öncesi ve sonrası ideal fikir üretme düzeylerini örnekleyen alıntılar Tablo 10'da verilmiştir.

Tablo 10

Deney ve Kontrol Gruplarında Yer Alan Fen Bilimleri Öğretmen Adaylarının Uygulama Öncesi ve Sonrası ÖTF'deki PABM1'e İlişkin Örnek Cevapları

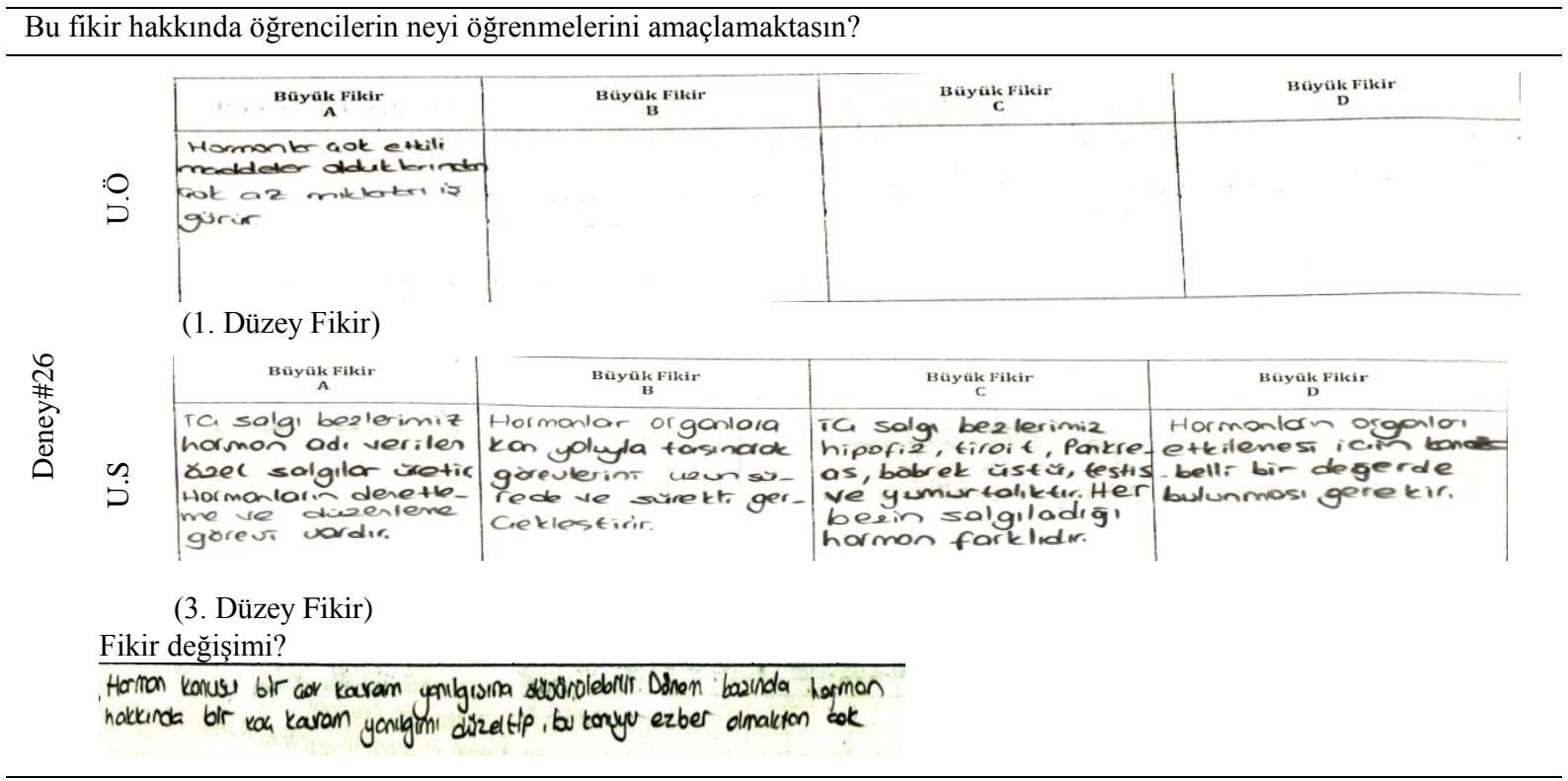


Tablo $10-$ Devam

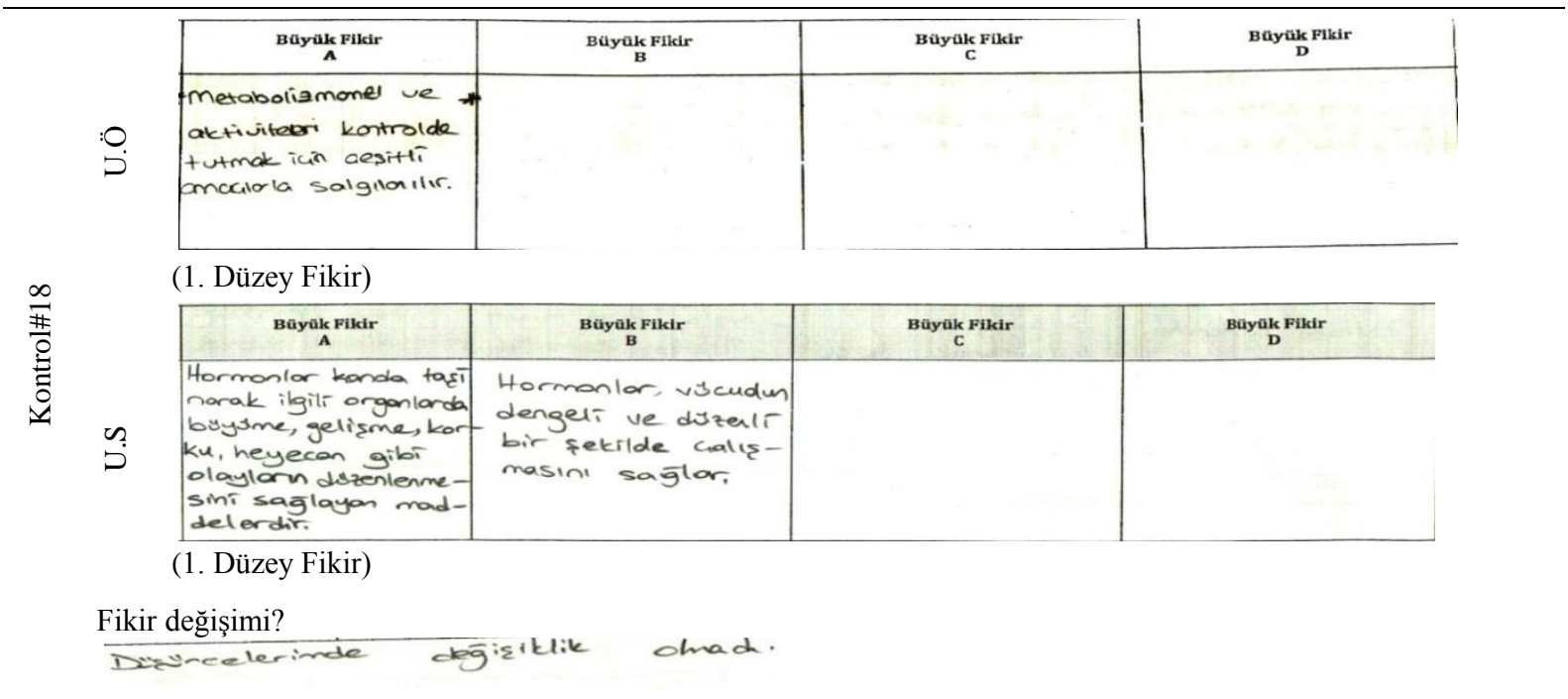

\section{Deney ve Kontrol Grubu Öğretmen Adaylarının Öğrenciyi Anlama Bilgisi Değişimleri}

- Yukarıdaki birinci soruya ait cevap sütunda ifade ettiğin büyük fikirleri öğrencilere öğretmeyle ilgili zorluklar ve sinırll1ıklar nelerdir? (PABM4)

- Yukarıdaki birinci soruya ait cevap sütunda ifade ettiğin büyük fikirleri öğretmeni etkileyecek öğrenci düşüncelerine ilişkin ne bilmektesin? (PAB5)

- Yukarıdaki birinci soruya ait cevap sütunda ifade ettiğin büyük fikirleri öğrencilere öğretmeni etkileyen başka faktörler nelerdir? (PAB6)

Deney ve kontrol grubunda yer alan öğretmen adaylarının vücudumuzdaki sistemler konularında ortaokul öğrencilerinin sahip oldukları ön bilgiler, kavram yanılgıları ve öğrenme zorluklarına ilişkin olarak uygulama öncesinde ürettikleri ideal fikirler bakımından büyük oranda boş/geçersiz ve zayıf düzeyde toplandıkları görülmüştür. Uygulama sonrasında ise deney grubu öğretmen adaylarının büyük çoğunluğunun orta ve yüksek düzeye geçerek daha fazla geçerli fikir ürettikleri görülmüştür. Buna karşın uygulama sonrasında kontrol grubu öğretmen adaylarının öğrenci anlayışlarına ilişkin üretmiş oldukları fikirlerde uygulama öncesine göre boş/geçersiz ve zayıf düzeyde kalan ortalama öğretmen adayı sayısında azalma olmasına rağmen, yüksek düzeyde kalan ortalama öğretmen adayı sayısında önemli bir artışın olmadığı görülmüştür. Tablo 11'de deney ve kontrol grubu öğretmen adaylarının uygulama öncesi ve sonrası öğrenci anlayışlarına ilişkin ortaya koymuş oldukları örnek fikirler sunulmuştur.

Tablo 11

Deney ve Kontrol Grubu Öğretmen Adaylarının ÖTF'deki PABM4'e İlişkin Örnek Cevapları

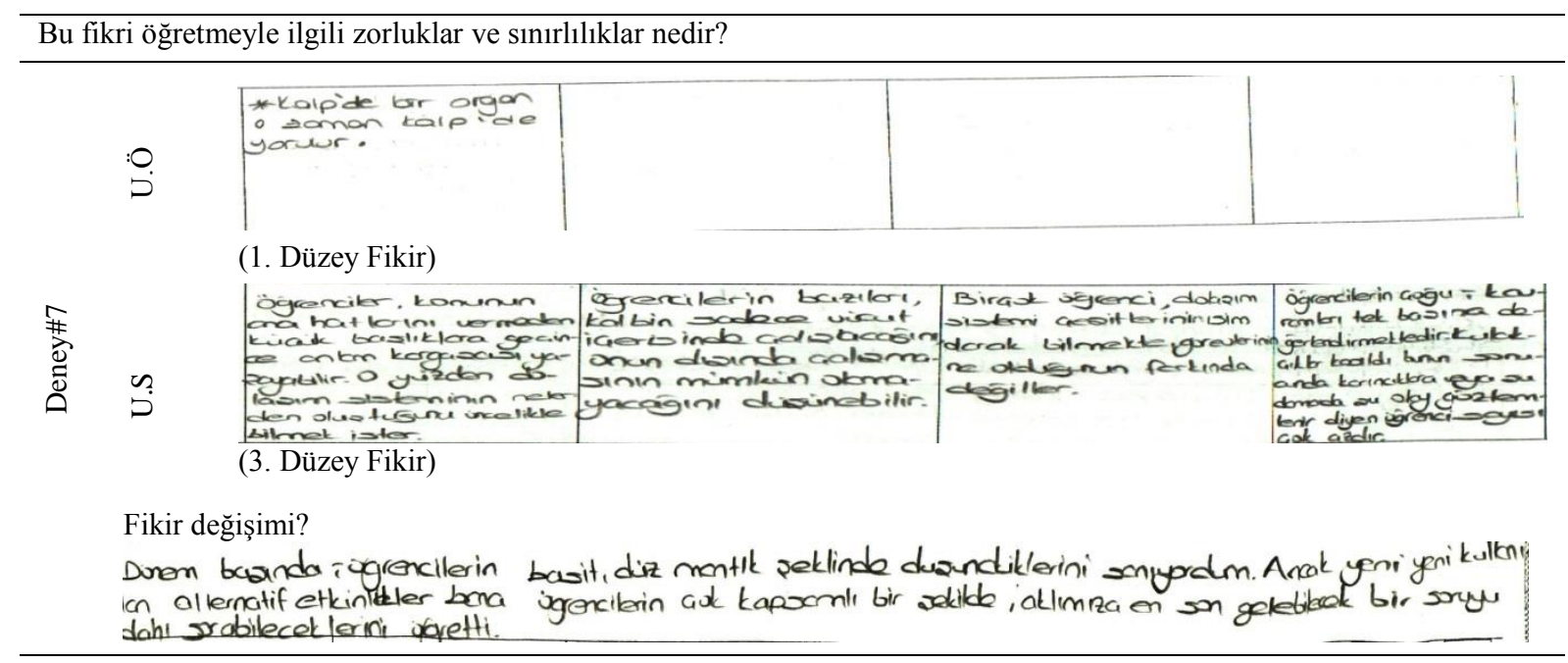




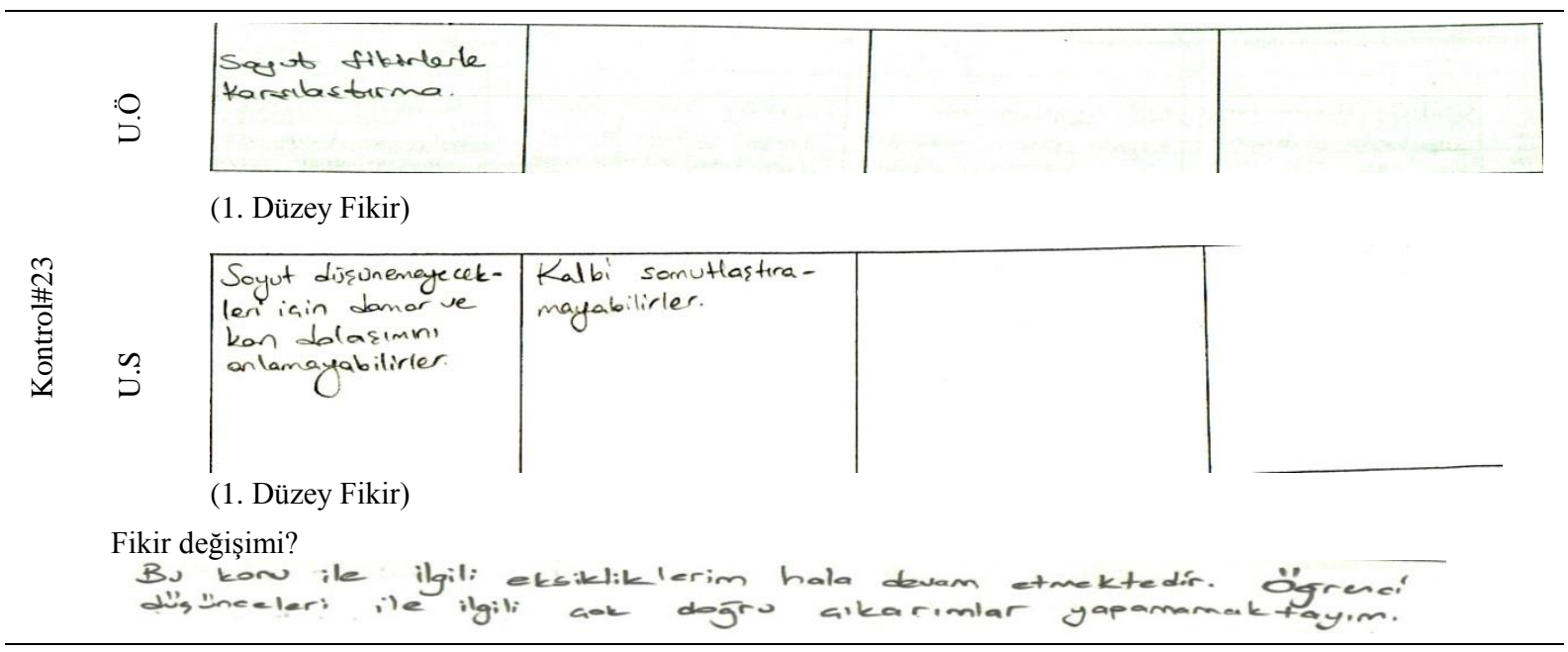

\section{Deney ve Kontrol Grubu Öğretmen Adaylarının Strateji, Yöntem ve Teknik Bilgisi Değişimleri}

- Yukarıdaki birinci soruya ait cevap sütunda ifade ettiğin fikirleri öğrencilerin öğrenmesi için kullanacağın öğretim stratejisi, yöntem ve tekniklerin nelerdir? (PABM7 )

Deney ve kontrol grubu öğretmen adaylarının uygulama öncesi içerik konularının öğretiminde kullanacakları strateji, yöntem ve teknik bilgisine ilişkin olarak içerik temsil formunda ortaya koydukları fikirler bakımından büyük oranda geçersiz ve zayıf düzeyde toplandıkları görülmektedir. Bunun yanı sıra uygulama öncesinde her iki grupta yer alan öğretmen adaylarının konuların nasıl öğretileceğine ilişkin ortaya koydukları fikirler bakımından yüksek düzeye ulaşan ortalama kişi sayısının çok az olduğu görülmektedir. Uygulama sonrasında deney grubundaki öğretmen adaylarının konuların öğretiminde kullanacakları strateji, yöntem ve teknik bilgisine ilişkin fikirleri bakımından büyük oranda orta ve yüksek düzeyde toplandıkları görülmüştür. Ayrıca deney grubunda ki öğretmen adaylarının yanlış veya boş düzeyde kalan ortalama kişi sayısında da önemli bir azalmanın olduğu görülmektedir. Bunun yanı sıra kontrol grubu öğretmen adaylarının uygulama sonrasında öncesine göre konuların öğretimi için ortaya koydukları strateji, yöntem ve teknik bilgisine ilişkin fikirler bakımından boş/geçersiz ve düşük düzeyde kalan kişi sayısında azalma olmasına rağmen, yüksek düzeyde toplanan kişi sayısında önemli bir artışın olmadığı görülmüştür. Tablo 12 'da deney ve kontrol grubu öğretmen adaylarının uygulama öncesi ve sonrası öğretim stratejisi, yöntem ve teknik bilgisine ilişkin örnek fikirlerini göstermektedir.

Tablo 12

Deney ve Kontrol Grubu Öğretmen Adaylarının ÖTF'deki PABM7'ye İlişkin Örnek Cevapları

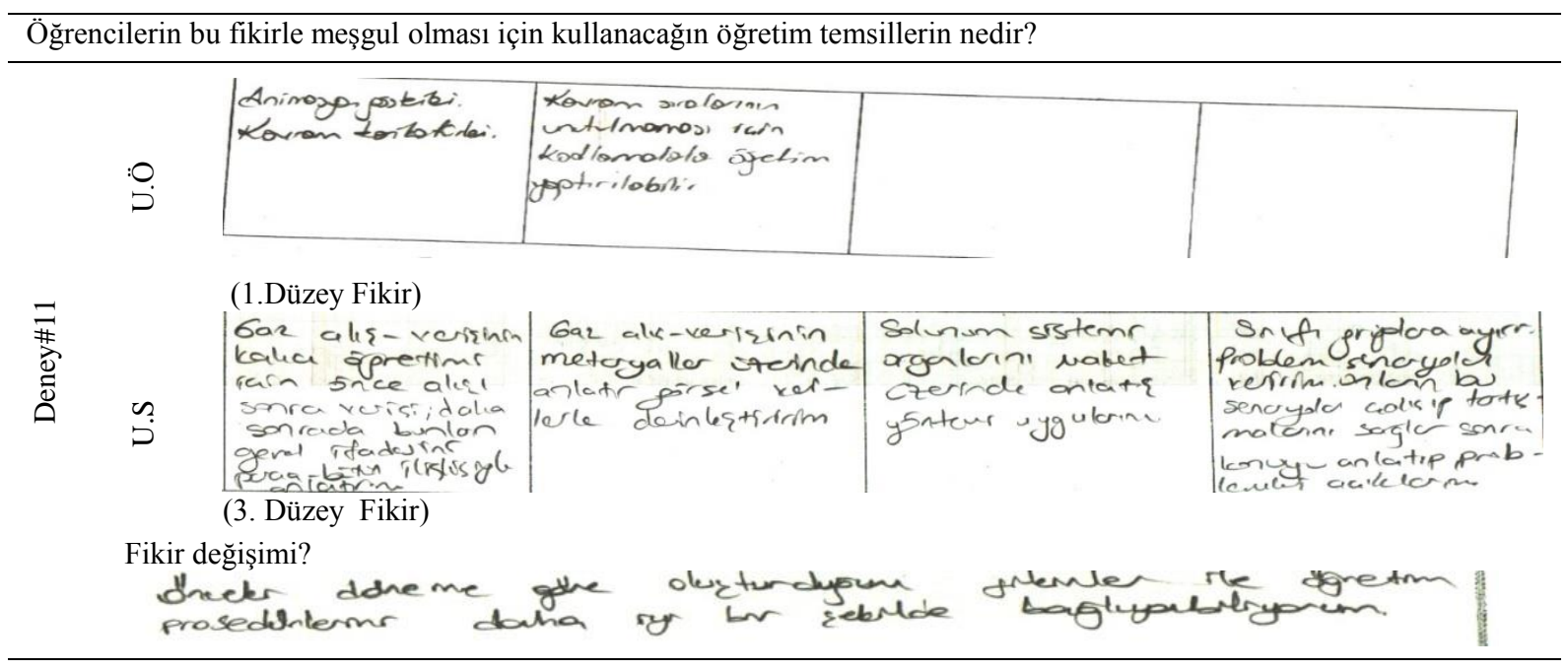


Tablo $12-$ Devam

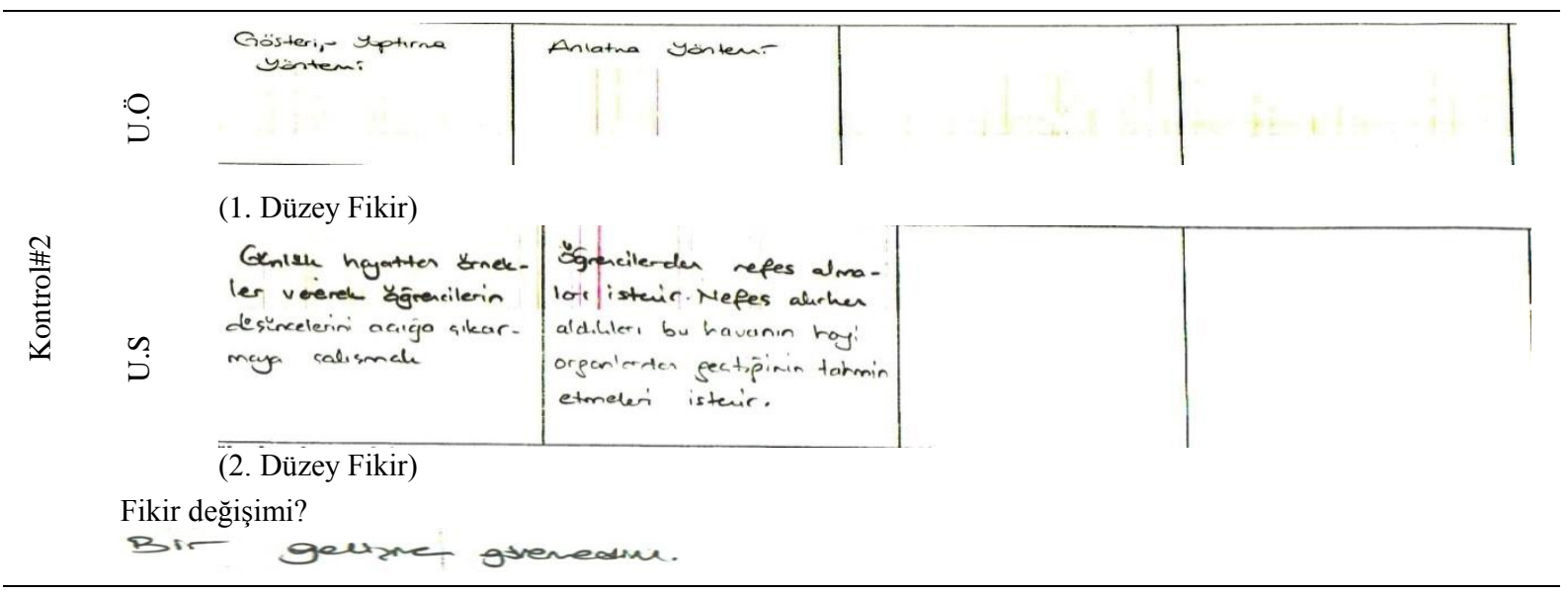

\section{Deney ve Kontrol Grubu Öğretmen Adaylarının Değerlendirme Bilgisi Değiş̧imleri}

- Yukarıdaki birinci soruya ait cevap sütunda ifade ettiğin büyük fikirlere ilişkin öğrenci anlayışlarını değerlendirmede kullanacağın özel yöntemler nelerdir?(PABM8)

Tablo 13

Deney ve Kontrol Grubu Öğretmen Adaylarının İ̧erik Temsil Formu PAB8 Örnek Cevapları

Bu fikirlere ilişkin oluşan öğrenci anlayışlarını belirlemede kullanacağın özel işlemler nedir?

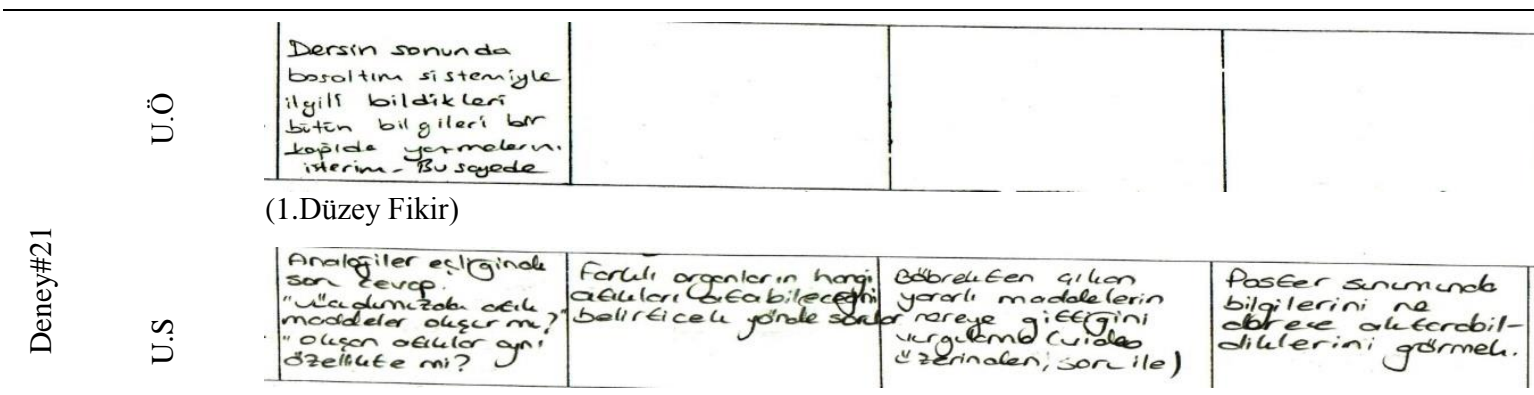

(3. Düzey Fikir)

Fikir değişimi?

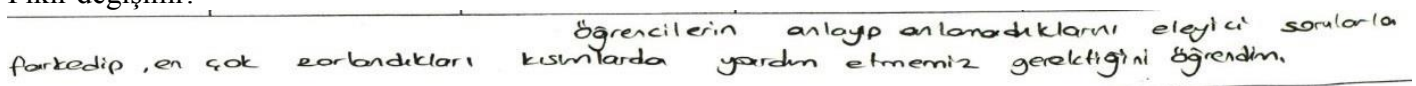

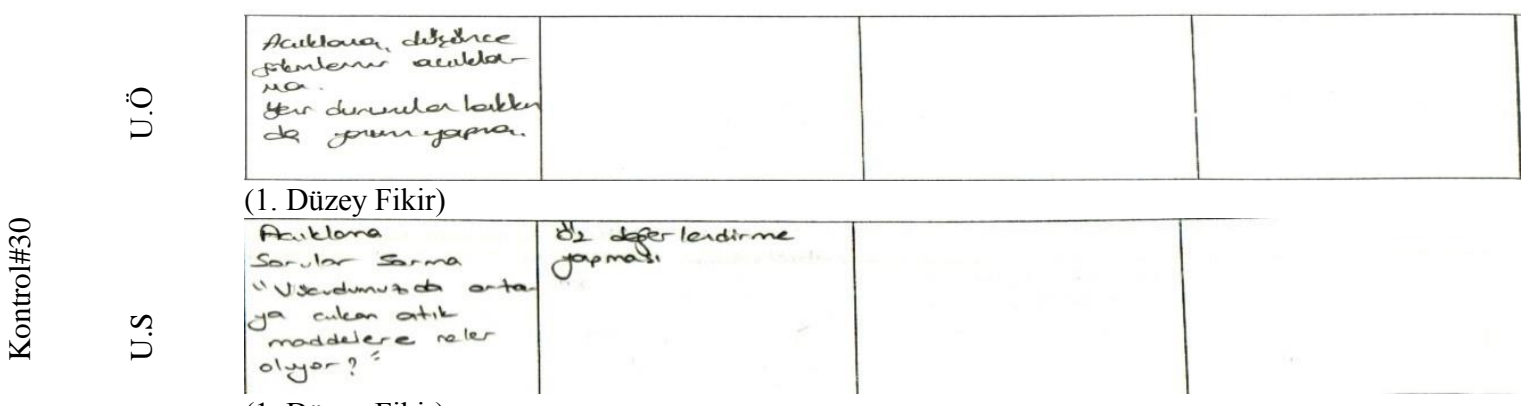

(1. Düzey Fikir)

Fikir değişimi?)

Filerim degisnedi

Tablo 13'de, deney ve kontrol grubu öğretmen adaylarının uygulama öncesi ve sonrası öğrenci öğrenmelerini nasıl değerlendireceklerine ilişkin üretmiş oldukları fikirleri temsil etmektedir. Vücudumuzdaki Sistemler konularında deney ve kontrol grubu fen bilgisi öğretmen adayları uygulama öncesinde içerik temsil formunda öğretmek istedikleri temel fikirlerle ilgili olarak öğrenci öğrenmelerinin nasıl değerlendirileceğine ilişkin fikirleri 
bakımından, büyük oranda boş/geçersiz ve zayıf düzeyde toplandıkları görülmektedir. Uygulama sonrasında ise deney grubu öğretmen adaylarının öğrenci öğrenmelerinin nasıl değerlendirileceğine ilişkin ideal fikirler bakımından büyük oranda yüksek ve orta düzeyde toplandıkları görülmüştür. Uygulama sonrasında ise kontrol grubundaki öğretmen adaylarının öğrenci öğrenmelerinin nasıl değerlendirileceğine ilişkin fikirleri bakımından boş/geçersiz ve zayıf düzeyde toplanan kişi sayısında azalma olduğu fakat yüksek düzeyde toplanan ortalama öğretmen adayı sayısında da önemli bir artışın olmadığı anlaşılmaktadır.

\section{Sonuç ve Tartışma}

$\mathrm{Bu}$ araştırma, Vücudumuzdaki Sistemler ünitesinde yer alan konulara yönelik PDÖ uygulamalarının fen bilimleri öğretmen adaylarının PAB yapılarının gelişimine etkisini belirlemek amacıyla tasarlanmıştır. Alan yazın incelendiğinde fen bilimleri öğretmen adaylarının program, öğrenciyi anlama, strateji, yöntem ve teknik ile değerlendirme bilgisi boyutlarına ait PAB'larının, fen bilimlerinde özel bir konu içeriğini öğretirken nasıl kullanıldığına ilişkin öğretim uyumunu ifade ettiği görülmektedir.

Araştırma sonuçlarına göre fen bilimleri öğretmen adaylarının PAB gelişim durumu iki boyutta tartışılmıştır. İlk olarak, deney ve kontrol grubunda yer alan fen öğretmen adaylarının uygulama öncesi ve sonrası bilinen bir ürün olarak sunulan fen ile sorgulama yoluyla elde edilen fen arasındaki öğretim yaklaşımı tercihleri ve adayların fen bilimlerinde öğretim yaklaşımı tercihlerine ilişkin gerekçelerinin tartışılmasıdır. İkinci olarak ise fen bilimleri öğretmen adaylarının, PAB alt boyutlarına ilişkin gelişim durumlarının tartışılmasıdır.

Araştırma sonuçları, iki ayrı öğrenme programına katılan deney ve kontrol grubu öğretmen adaylarının içerik konularına ilişkin olarak fen öğretim yaklaşımı tercihlerinin uygulama öncesinden sonrasına önemli oranda değişim gösterdiğini ortaya koymaktadır. Uygulama öncesinde her iki grupta yer alan öğretmen adaylarının da, ağırlıklı olarak öğrencilerin fene ilişkin bilgiyi hazır olarak öğrenmesi gerektiği yönünde bir görüşe sahip oldukları tespit edilmiştir. Bunun yanında uygulama sonrasında ise deney grubu öğretmen adaylarının fen öğretim uyumlarının, kontrol grubundaki öğretmen adaylarına göre daha büyük oranda sorgulama ve keşfederek öğrenme yönünde bir fen öğretim anlayışına yöneldiği görülmektedir. Günümüzde birçok eğitim çevresi, fen bilimleri öğretmenlerinin niteliğini geliștirmek için, öğretmen hazırlı̆̆ında fen içeriğinin reform temelli uygulamalarla bütünleştirildiği öğrenme süreçlerinin çoğaltılması gerektiğine vurgu yapmaktadır (Friedrichsen ve diğ., 2011). Mc Conell ve diğerleri (2008), PDÖ’yü fen bilimleri öğretmenlerinin öğretme ve öğrenmeye ilişkin düşüncelerine rehberlik edecek bir mesleki gelişim yapılandırması olarak kullandıkları araştırmalarının sonuçları, bu araștırmanın sonuçlarıyla paralellik göstermektedir. Araştırmacılar, PDÖ'nün fen bilimleri öğretmenlerinin öğretime ilişsin düşünce yapılarını incelemede ve kendi uygulamaları üzerine eleștirel düşünme yeteneklerini geliştirilmede sorgulayıcı bir araç olarak onlara yardım edeceğini ifade etmişlerdir. Yine Shin ve diğerleri (2010), fen öğretmenlerinin öğretim anlayışları üzerine PDÖ uygulamalarının etkisini inceledikleri araştırma sonuçları, bu araştırmanın sonuçlarıyla uyumludur. Araştırmacılar, uygulama sonrasında fen bilimleri öğretmenlerinin daha çok reform temelli öğretim süreçlerine yöneldiğini ortaya koymuşlardır. Bu araştırmanın sonuçları, PDÖ uygulamalarının fen öğretmen adaylarının öğretim uyumlarına, reform temelli öğretim yönünden daha fazla katkı sağladığını göstermektedir. Araştırmanın bu sonucu Torp ve Sage'nin (2002), öğretmenlerin reform temelli fen öğretim anlayıșını geliştirmede sorgulama temelli pedagojik uygulamaların etkisini ortaya koyduğu araştırma sonuçlarıyla paralellik göstermektedir. Benzer şekilde yine Weizman ve diğerleri (2008), araştırmalarında, sorgulama temelli pedagojik bir yaklaşım olarak PDÖ'nün, fen bilimleri öğretmenlerinin öğretim uyumunu geliştirmede önemli katkılar sağladığını ortaya koymuşlardır. İfade edilen araştırmanın sonuçlarına dayalı olarak değerlendirme yapıldığında, deneyimsiz fen bilimleri öğretmen adaylarının biçimlenmemiş zayıf bir yapıda olan öğretim uyumlarını, lisans eğitimleri boyunca araştırma ve sorgulamaya dayalı pedagojik deneyimlerle etkili bir şekilde yapılandırabileceklerini göstermektedir. Bu bakımdan öğretmen eğitimcilerinin, lisans eğitimi aşamasında fen bilimleri öğretmen adaylarının öğretim uyumuna ilişkin anlayışlarının biçimlenmesinde sorgulama temelli bir pedagojik yaklaşım olarak PDÖ uygulamalarını alan eğitimi dersleri içerisine yerleştirmeleri önemlidir (Schuster ve diğ., 2007).

Öğretmen adaylarının PDÖ pedagojisiyle arzulanan öğrenme çıtılarını edinmeleri, ancak onların kendi uygulamaları üzerine yansıtmada bulunmaları ve başkalarıyla etkili bir şekilde çalışabilen usta problem çözücüler olmalarını destekleyen oluşumların sağlanmasıyla gerçekleşebilir (Pourshafie ve Muray-Harvey, 2013). Goodnough ve Nolan (2008), yaptıkları çalışmada PDÖ'nün fen bilimleri öğretmenlerinin nasıl öğretmeleri gerektiğiyle ilgili düşünceleri üzerine yansıtmada bulunmalarına imkân veren bir araç olarak hizmet edebileceğini belirtmişlerdir. Ayrıca PDÖ’nün öğretmenler için özel bir disiplinle ilişkili fikirlerin, kavramların ve süreçlerin incelenmesi yolunda önemli firsatlar sunduğuna da dikkat çekmişlerdir. Alan yazında pek çok araştırma PDÖ uygulamalarıyla elde edilen deneyimlerin, fen bilimleri öğretmenleri ve adaylarının öğretim uyumlarının gelişimine ve öğrenmeye ilişkin bilgi yapılanması sürecine önemli katkılar sağladığını göstermektedir (Faikhamta, 2013; Goodnough ve Hung, 2008; McConnell ve diğ., 2008; Shin ve diğ., 2010; Zhang ve diğ., 2010; Zhang, Lundeberg ve Eberhardt, 2011). 
Park, Jang, Chen ve Jung (2011) fen bilimleri öğretmenlerinin PAB gelişimlerinin, reform amaçlı bir öğretim anlayışı sergilemeyle son derece ilişkili olduğunu ifade etmektedir. Fen bilimleri öğretmeni eğitiminde reform temelli uygulamalar, yani araştırma ve sorgulamaya dayalı öğrenme süreçleri, öğretmen adaylarının $P A B$ yapısının gelişimine önemli katkılar sağlayabilmektedir. Fen öğretmen adaylarının daha belirgin bir fen öğretim uyumuna sahip olmaları, onların öğrenci öğrenmeleri ve öğretim temsillerine ilişkin etkili bir anlayış geliştirmelerine firsat verilmesi yoluyla mümkün olmaktadır. Brown, Friedrichsen ve Abell (2013), yaptıkları araştırmada fen öğretmen adaylarının lisans dönemindeki öğretim uyumlarının, değişime karşı çok dirençli olduğunu ve ayrıca bu durumun öğretmen adaylarının PAB'ını geliştirmede öğretmen eğitimcilerinin karşısına çok ciddi bir bariyer olarak çıktığını belirtmişlerdir. Bu araştırmanın sonucu bağlamında değerlendirildiğinde, PDÖ uygulamalarının, fen bilimleri öğretmen adaylarının etkisiz öğretim uyumlarını değiştirmek için zayıf bir şekilde yapılandırmış oldukları bilgi yapılarını sorgulamalarına imkân tanıyan etkili bir yol olduğu ifade edilebilir. Bunun yanında, Friedrichsen ve diğerleri (2011), alan yazında birçok fen öğretim uyumu çalışmasının çokta etkili sonuçlar vermediğine dikkat çekmişlerdir. Araştırmacılar fen öğretim uyumu çalışmalarının birçok kez belirgin olmayan yollar içersin de şekillendiğini ve bu durumun aslında çok sağlıklı bir bilgi yapılandırma süreci olmadığını ifade etmişlerdir. Bu araştırmanın sonuçlarına bakıldığında ise PDÖ’nün açık ve anlaşılır bir bilgi yapılandırması yolu olarak fen bilimleri öğretmen adaylarının öğretim uyumuna ilişkin anlayışlarının belirgin bir şekilde değişmesine oldukça katkı sağladığı görülmektedir.

Fen bilimleri öğretmeni adaylarının sahip oldukları PAB'a ilişkin çeşitli bilgi yapılarının gelişimi, fen öğretim oryantasyonlarının gelişimiyle çok yakından ilişkilidir (Brown ve diğ, 2013; Campbell ve diğ., 2014). Bunun yanında Park ve Oliver'ın (2008) çalışmalarında PAB'a ilişkin alt bilgi bileşenlerinin gelişiminin farklı deneyimler ve bilgilerin edinilmesi sonucunda şekillendiğini ortaya koymuşlardır. Ayrıca araştırmacılar bu çalışmalarında fen bilimleri öğretmen adaylarının sahip oldukları PAB alt bileşenlerinin doğasına odaklanmanın PAB'1 geliştirmede etkili bir yol olduğunu da ortaya koymuşlardır. Yapılan bu çalışmada, aslında PDÖ öğrenme uygulamalarıyla fen bilimleri öğretmen adaylarının mevcut PAB alt bilgi bileşenlerine ilişkin bir öz düzenleme yapılması sağlanmaktadır. Bu uygulamalarla öğretmen adayları, sahip oldukları PAB bilgi temellerini sorgularken aynı zamanda fen bilimlerini öğrenme ve öğretmenin karışık doğasını anlama ve buna ilişkin süreçleri yönetme yollarını geliştirme imkânını da bulmaktadırlar (Nilson ve Lougran, 2012).

$\mathrm{Bu}$ bağlamda düşünüldüğünde, PDÖ uygulamalarıyla fen bilimleri öğretmen adaylarının PAB alt bilgi boyutlarının gelişimi, aynı zamanda onların fen öğretim uyumlarının da gelişimini desteklemektedir. Park ve Oliver (2008), fen bilimleri öğretmenlerinin bilgi dinamiklerinin iyileştirilmesi, ancak yeni ve etkili uygulamalar üzerinden sorgulanma ve yansıtma imkânı sunan yollarla sağlanabileceğini belirtmişlerdir. Ayrıca araştırmacılar, fen bilimleri öğretmenlerinin öğretime ilişkin anlayışlarındaki en güçlü değişimlerin, uygulamalar içerisinde edinilecek deneyimler sonucu ortaya çıkabileceğini ifade etmişlerdir. PDÖ uygulamaları, bu kapsamda fen bilimleri öğretmen adayları için yeni bir fen öğretim uyumu anlayışının sergilenmesinde kendi bilgi dinamikleri üzerine sorgulama ve yansıtma imkânı sağlayan önemli bir pedagojik dönüşümü ortaya koymaktadır.

Käpylä ve diğerleri (2009), fen bilimleri öğretmenlerinin öğretim uyumlarının kendi eğitimsel geçmişleriyle büyük oranda ilişkili olduğunu belirtmektedir. Günümüzde ortaokul öğretmen eğitiminin temel amac1, bilgiyi anlamlı öğrenme süreçleri içerisinde yapılandıran ve öğrenci merkezli öğretim uyumunu özümseyen öğretmenlerin yetiştirilmesi olarak tanımlanmaktadır. Yine araştırmacılar, ifade edilen öğrenci merkezli öğretim anlayışının, bugün aday öğretmenler tarafından etkili bir şekilde kullanılamadığını, bu durumun daha çok aday öğretmenlerin zayıf olan alan bilgilerini gizlemek amaçlı kullanıldığını ifade etmişlerdir. Ayrıca bu duruma ilişkin eksikliklerin lisans döneminde giderilmemesi durumunda mesleğe başladıktan sonrada 1srarla sürdürüldüğüne dikkat çekmişlerdir. İfade edilen bu durum değerlendirildiğinde, özellikle sürekli aktiviteye dayalı öğretim anlayışının ve bunun da öğrenci merkezli bir öğretim uyumunun gereği olarak sunulmasının aslında çoğu kez fen bilimleri öğretmen adaylarının zayıf içerik bilgilerini gizlemekle açıklanabilmektedir.

Anderson (2002), fen eğitimi reformları kapsamında arzulanan sorgulama temelli öğretim uyumlarının sağlanmasının, öğretmenlerin öğrencilerin rollerine, öğrenci çalışmalarının doğasına ve kendi rollerine odaklanmayı gerektirdiğini ifade etmiştir. $\mathrm{Bu}$ bağlamda reform temelli fen öğretim uyumu misyonunu etkinleştirmede, eğitimin lideri olan öğretmenler ve adaylar arasında işbirlikli ve takım çalışmasına dayalı bir iklim yaratılmaya odaklanılmalı ve onların öğretime ilişkin değerlerini ve inanışlarını yansıtabilme imkânı sağlanmalıdır. Bu araştırmanın sonuçları yukarıdaki düşünceyle uyumlu bir şekilde fen öğretmen adaylarını kendi bilgi yapılarını, öğrenci öğrenmeleri bağlamında sorgulayarak biçimlendirdikleri bir anlayışa yönelttiğini göstermektedir. Kuusisaari (2013), işbirlikli öğrenme deneyimleri içerisinde öğretmen ve öğretmen adaylarının nasıl çalışmaları ve düşünmeleri gerektiğine ilişkin önemli fırsatlar bulduklarını ifade etmiş̧tir. Ayrıca öğretmenlerin düşüncelerini ve deneyimlerini paylaşması bağlamında işbirlikli oluşumların, öğretmenlerin kuramsal ve uygulama bilgileri arasında köprü kurmasını kolaylaştırdığı vurgulanmaktadır (Barnett ve Friedrichsen, 2015). Bu bağlamda araştırmanın sonuçları yukarıdaki fikri destekler niteliktedir. Çünkü bu 
araştırmada fen bilimleri öğretmen adaylarının, PDÖ uygulamalarıyla başka öğretmenlerin deneyimlerinden ve bilgilerinden yararlanması yoluyla kendi düşünceleri üzerine çeşitli yansıtma firsatları buldukları görülmüştür.

Faikhamta, Coll ve Roadrangka (2009), yaptıkları çalışmada fen bilimleri öğretmen adaylarının öğrenmeye ilişkin fikirlerinin sorgulanması yoluyla $P A B$ 'nn geliştirilebileceğini göstermişlerdir. Çalışma sonunda fen bilimleri öğretmen adaylarının özellikle reform temelli fen öğretim uyumu gelişimine yönelik daha fazla farkındalık edindikleri gözlenmiştir. İşbirlikli uygulamalar içerisinde fen bilimleri öğretmen adaylarına eğer etkili pedagojik destek sağlanırsa, sahip oldukları PAB bilgi temsillerini arındırma, yapılandırma ve öğretime ilişkin inanışlarını test etme firsatı bulacaklardır. Bu amaçlar doğrultusunda PDÖ, fen bilimleri öğretmen adaylarının işbirlikli çalışmalar yoluyla PAB'ları üzerine yansıtma yapmalarına yardım etmede önemli bir pedagojik destek sağlamaktadır. Bu çalışmada fen bilimleri öğretmen adayları, PDÖ uygulamaları içerisinde bilgi edinme yollarını kullanarak, reform temelli bir PAB yapısı geliştirime firsatı yakalamışlardır. Ayrıca yukarıdaki ifadeleri destekler nitelikte, Van Driel (2010) çalışmasında fen bilimleri öğretmenlerinin PAB'ını yeniden revize etme ve derinleştirmede bir bakıma öğrenmeyi sorgulama anlamına gelen işbirlikli öğrenme tartı̧̧alarının, sürece önemli etkileri olduğunu ortaya koymuştur. Yine diğer bir çalışmada McConnell, Parker ve Eberhardt (2013), işbirlikli bir öğrenme pedagojisi olan PDÖ'nün, önemli bilgileri tanımlayarak, sorular sorarak, hipotezler kurarak, sorgulama yaparak ve bulguları analiz ederek ve problemlerin çözümü için birlikte çalışma yollarını tercih ederek, fen bilimleri öğretmenlerinin anlamlı öğrenme ihtiyaçlarını karşılayan etkili bir profesyonel gelişim stratejisi olduğunu göstermişlerdir. Aktiviteler ve deneyimler, öğretmen adaylarının yeni bilgiyi işbirliği yoluyla organize ettiği ve yapılandırdığı bir çevrenin olmasına izin vermelidir (Weinburg, 2007). Günümüzde donanımlı öğretmenlerin hazırlanmasındaki temel düşünce, hem konu alanı hem de pedagoji tabanlı bir bilgi bütünlüğünün sağlandığı yapılandırmayı zorunlu kılmaktadır (Akkerman ve Bakker, 2011; Roychoudhry ve Rice, 2010). Fen eğitiminde sistemin ihtiyaç duyduğu etkili öğretim süreçlerine yön verecek ve bu konuda mesleki uzmanlık sergileyecek öğretmenlerin yetişmesi, hizmet öncesi programın verimli bir şekilde yapılandırılmasıyla mümkündür. Fen eğitiminde öğretim kalitesini iyileştirme, öğrenci ve program arasında köprü görevi gören öğretmenin sahip olduğu bilgi temsillerinin ne kadar geliştiğiyle doğru orantılıdır. Sonuç olarak söyleyebiliriz ki, fen bilimleri öğretmen adaylarının öğrenme ve öğretim uygulamaları üzerine yapacakları sorgulamalar, PAB yapılarını geliştirmek için önemli firsatlar sunmaktadır. Bu sonuçlar doğrultusunda gelecekte yapılacak araştırmalar için iki temel öneri yapılabilir. Bunlar; fen bilimleri öğretmen adaylarının, lisans dönemi boyunca aldıkları alan eğitimi derslerinde, öğrenme ve öğretmeye ilişkin etkili bir uyum oluşturmaları için PAB yapılarının daha fazla sayıda sorgulama temelli pedagojik uygulamalarla desteklenmesi gerekmektedir. Yine araştırmacıların ve öğretmen eğitimcilerinin, farklı fen konularında öğretmen adaylarının PAB yapılarının gelişimi ve dönüşümü üzerine PDÖ uygulamalarının etkilerini inceleyecekleri daha fazla çalışma yapmaları gerekmektedir. 


\section{Kaynakça/References}

Abell, S. K. (2007). Research on science teacher knowledge. In S. K. Abell \& N. G. Lederman (Eds.), Handbook of research on science education (pp.1105-1151). New Jersey: Lawrence Erlbaum Associates.

Abell, S. K., Appleton, K., \& Hanuscin, D. L. (2010). Desing and teaching the elementary science methods course. New York: Routledge, Taylor \& Francis Group.

Akerson, V. L., Pongsanon, K., Park Rogers, M. A., Carter, I., \& Galindo, E. (2015). Exploring the use of lesson study to develop elementary preservice teachers' pedagogical content knowledge for teaching nature of science. International Journal of Science and Mathematics Education, 15(2), 293-312.

Akkerman, S. F., \& Bakker, A. (2011). Boundary crossing and boundary objects. Review of Educational Research, 81, 132-169.

Anderson, R. D. (2002). Reforming science teaching: What research says about inquiry? Journal of Science Teacher Education, 13(1), 1-12.

Anderson, C. W. \& Smith, E. L. (1987). Teaching science. In V. Richardson-Koehler (Ed.), Educators handbook: A. Research perspective (pp. 84-111). New York: Longman.

Albanese, M. A., \& Mitchell, S. (1993). Problem based learning: A review of literatüre on its outcomes and implementation issues. Academic Medicine, 68(1), 52-81.

Appleton, K. (2008). Developing science pedagogical content knowledge through mentoring elementary teachers. Journal Science Teacher Education, 19, 523-545.

Bardak, Ș. ve Karamustafoğlu, O. (2016). Fen bilimleri öğretmenlerinin kullandıkları öğretim strateji, yöntem ve tekniklerin pedagojik alan bilgisi bağlamında incelenmesi. Amasya Eğitim Fakültesi Dergisi, 5(2), 567-605.

Barnett, E., \& Friedrichsen, P. J. (2015). Educative mentoring: How a mentor supported a preservice biology teacher's pedagogical content knowledge development. Journal of Science Teacher Education, 26, 647668.

Barrows, H. S. (2002). Is it truly possible to have such a thing as PBL?. Distance Education, 23(1), 119-122.

Baturay, M. H., \& Bay, Ö. F. (2010). The effects of problem-based learning on the classroom community perceptions and achievement of web-based education students. Computers \& Education, 55, 43-52.

Beck, J. (2007). An exploration of the relationship between case study methodology and learning style preference. Journal of Science Teacher Education, 18, 423-430.

Bertram, A., \& Loughran, J. (2012). Science teachers' views on cores and pap-ers as a framework for articulating and developing pedagogical content knowledge. Resarch Science Education, 42, 1027-1047.

Bond-Robinson, J. (2005). Identifying pedagogical content knowledge (PCK) in the chemistry laboratory. Chemistry Education Research and Practice, 6(2), 83-103.

Bozkurt, O., \& Kaya, O. N. (2008). Teaching about ozone layer depletion in Turkey: pedagogical content knowledge of science teachers. Public Understanding of Science, 17, 261-276.

Brown, P., Friedrichsen, P. \& Abell, S. (2013). The development of prospective secondary biology teachers PCK. Journal Science Teacher Education, 24, 133-155.

Büyüköztürk, Ş., Çakmak, E., Akgün, Ö., Karadeniz, Ş. ve Demirel, F. (2010). Bilimsel araştırma yöntemleri (5. Baskı). Ankara: Pegem Yayıncılık.

Campbell, T., Zuwallack, R., Longhurst, M., Shelton, B. E., \& Wolf, P. G. (2014). An examination of the changes in science teaching orientations and technology-enhanced tools for student learning in the context of professional development. International Journal of Science Education, 36(11), 1815-1848.

Campbell, T., Longhurst, M. L., Wang, S-K., Hsu, H-Y., \& Coster, D. C. (2015). Technologies and reformedbased science instruction: the examination of a professional development model focused on supporting science teaching and learning with technologies. Journal of Science Education and Technology, 24(5), 562-579. doi:10.1007/s10956-015-9548-6

Canbazoğlu, S. (2008). Fen bilgisi öğretmen adaylarının maddenin tanecikli yapısı ünitesine ilişkin pedagojik alan bilgilerinin değerlendirilmesi. (Yüksek lisans tezi). Gazi Üniversitesi Eğitim Bilimleri Enstitüsü, Ankara. 
Canbazoğlu, S., Demirelli, H. ve Kavak, N. (2010). Fen bilgisi öğretmen adaylarının maddenin tanecikli yapısı ünitesine ait konu alan bilgileri ile pedagojik alan bilgileri arasındaki ilișkinin incelenmesi. İlkögretim Online, 9(1), 275-291.

Carlson, R. E. (1990). Assesing teachers' pedagogical content knowledge: Item development issues. Journal of Personal Evaluation in Education, 4, 157-163.

Cite, S., Lee, E., Menon, D., \& Hanuscin, D. L. (2017). Learning from rookie mistakes: Critical incidents in developing pedagogical content knowledge for teaching science to teachers. Studying Teacher Education, 13(3), 275-293.

Cirit, D. (2017). Fen bilgisi öğretmen adaylarının pedagojik alan bilgisi ve sınıf içi öğretimlerinin araştırılması. The Journal of Academic Social Science Studies, 63, 51-68.

Chan, K. K., \& Yung, B. H. (2015). On-site pedagogical content knowledge development. International Journal of Science Education, 37(8), 1246-1278.

Cobern, W. W., Schuster, D., Adams, B., Skjold, B., Mugaloglu, E., Bentz, A., et al. (2013, June). The Pedagogy of Science Teaching Test. Paper presented at the Third Annual Conference on Advancing the STEM Agenda, in Grand Valley State University, Grand Rapids, Michigan.

Cohen, L., Manion, L., \& Morrison, K. (2007). Research methods in education. (6nd ed.). New York: Routledge.

Cowie, B., Jones, A., \& Otrelcass, K. (2011). Re-engaging students in science: issues of assessment, funds of knowledge and sites for learning. International Journal of Science and Mathematics Education, 9, 347-366.

Creswell, J. W. (2003). Research design: Qualitative, quantitative and mixed methods approaches (2nd ed.). Thousand Oaks, CA: Sage.

Creswell, J. W., \& Clark, V. L. (2007). Designing and conducting mixed methods research. Thousand Oaks, CA: Sage Publications.

Demirdöğen, B., Hanuscin, D. L., Uzuntiryaki-Kondakçi, E., \& Köseoğlu F. (2015). Development and nature of preservice chemistry teachers' pedagogical content knowledge for nature of science. Research in Science Education, 46(4), 575-612. doi: 10.1007/s11165-015-9472-z.

De Simone, C. (2008). Problem-based learning: a framework for prospective teachers' pedagogical problemsolving. Teacher Development, 12(3), 179-191.

Dewey, J. (1938). Experience and education. A Touchstonebook, Kappa Delta Pi, New York.

Dias, M., Eick, C. J., \& Brantley-Dias, L. (2011). Practicing what we teach: A self-study in implementing an inquiry-based curriculum in a middle grades classroom. Journal Science Teacher Education, 22, 53-78.

Donnelly, D. F., \& Hume, A. (2015). Using collaborative technology to enhance pre-service teachers' pedagogical content knowledge in science. Research in Science \& Technological Education, 33(1), 61-87.

Dunlap, J. C. (2005). Problem-based learning and self-efficacy: How a capstone course prepares students for a profession. Educational Technology Research and Development, 53(1), 65-85.

Duschl, R. (2008). Science education in three-part harmony: Balancing conceptual, epistemic, and social learning goal. Review of Research in Education, 32, 268-291.

Mthethwa-Kunene, E., Onwu, G. O., \& de Villiers, R. (2015). Exploring Biology teachers' pedagogical content knowledge in the teaching of genetics in swaziland science classrooms. International Journal of Science Education, 37(7), 1140-1165.

Faikhamta, C., Coll, R. K., \& Roadrangka, V. (2009). The development of Thai pre-service chemistry teachers' pedagogical content knowledge: from a methods course to field experience. Journal of Science and Mathematics, 32(1), 18-35.

Faikhamta, C. (2013). The development of in-service science teachers' understandings of and orientations to teaching the nature of science within a PCK-based NOS course. Research Science Education, 43(2), 847869.

Fortus, D., \& D. Vedder-Weiss. (2014). "Measuring students' continuing motivation for science learning." Journal of Research in Science Teaching, 51(4), 497-522.

Fraenkel, J. R., \& Allen, N. E. (2006). How to design and evaluate research in education. (6nd ed.). Boston: McGraw Hill. 
Fraser, S. P. (2016). Pedagogical content knowledge (PCK): Exploring its usefulness for science lecturers in higher education. Research in Science Education, 46, 141-161.

Friedrichsen, P. (2002). A substantive-level theory of highly-regarded secondary biology teachers' science teaching orientations. (Unpublished doctoral dissertation). The Pennsylvania State University, University Park.

Friedrichsen, P., \& Dana, T. (2005). A substantive-level theory of highly-regarded secondary biology teachers'science teaching orientations. Journal of Research in Science Teaching, 42(2), 218-244.

Friedrichsen, P., Van Driel, J. H., \& Abell, S. K. (2011). Taking a closer look at science teaching orientations. Science Education, 95, 358-376.

Geddis, A. N. (1993). Transforming content knowledge: Learning to teach about isotopes. Science Education, 77, 575-591.

Gess-Newsome, J. (1999). Pedagogical content knowledge: An introduction and orientation. In J. GessNewsome \& N. G. Lederman (Eds.), Examining Pedagogical Content Knowledge (pp. 3-17). Dordrecht, The Netherlands: Kluwer Academic.

Goodnough, K., \& Cashion, M. (2006). Exploring problem-based learning in the context of high school science: Design and implementation issues. School Science and Mathematics, 106 (7), 280-295.

Goodnough, K. C., \& Hung, W. (2008). Engaging teachers' pedagogical content knowledge: Adopting a ninestep problem-based learning model. The Interdisciplinary Journal of Problem-Based Learning, 2(2), 61-90.

Goodnough, K. (2006). Enhancing pedagogical content knowledge through self-study: An exploration of problem-based learning. Teaching in Higher Education, 11(3), 301-318.

Goodnough, K., \& Nolan, B. (2008). Engaging elementary teachers' pedagogical content knowledge: Adopting problem-based learning in the context of science teaching and learning. Canadian Journal of Science, Mathematics and Technology Education, 8(3), 197-216.

Grossman, P. L. (1990). The making of a teacher: Teacher knowledge and teacher education. New York: Teachers College Press.

Großschedl, J., Harms, U., Kleickmann, T., \& Glowinski, I. (2015). Preservice biology teachers' professional knowledge: Structure and learning opportunities. Journal of Science Teacher Education, 26, 291-318.

Hanuscin, D., Lee, M. H., \& Akerson, V. L. (2010). Elementary teachers' pedagogical content knowledge for teaching the nature of science. Science Education, 95(1), 145-167.

Henze, I., Van Driel, J. H., \& Verloop, N. (2008). Development of experienced science teachers' pedagogical content knowledge of models of the solar system and the universe. International Journal of Science Education, 30(10), 1321-1342.

Hestness, E., Mcginnis, J. R., Riedinger, K., \& Marbach-Ad, G. (2011). A study of teacher candidates' experiences investigating global climate change within an elementary science methods course. Journal Science Teacher Education, 22, 351-369.

Hmelo-Silver, C. E., \& Barrows, H. S. (2006). Goals and strategies of a problem-based learning facilitator. The Interdisciplinary Journal of Problem-Based Learning, 1(1), 21-39.

Hmelo-Silver, C. E. (2004). Problem-based learning: What and how do students learn? Educational Psychology Review, 16(3), 235-266.

Hume, A., \& Berry, A. (2011). Constructing cores-a strategy for building PCK, in pre-service science teacher educationres. Science Education, 41, 341-355.

Hume, A., \& Berry, A. (2013). Enhancing the practicum experience for pre-service chemistry teachers through collaborative core design with mentor teachers. Research in Science Education, 43(5), 2107-2136.

Hung, W. (2006). The 3C3R model: A conceptual framework for designing problems in PBL. Interdisciplinary Journal of Problem-Based Learning, 1(1), 55-77.

Iserbyt, P., Ward, P., \& Li, W. (2015). Effects of improved content knowledge on pedagogical content knowledge and student performance in physical education. Physical Education and Sport Pedagogy, 22, 71-88. doi: 10.1080/17408989.2015.1095868. 
Jang, S. J. (2012). Developing a peer-coaching model for enhancing the pedagogical content knowledge of preservice science teachers. In: Tan, K.C.D. \& Kim, M. (Ed.), Issues and Challenges in Science Education Research: Moving Forward (pp.107-123). Dordrecht: Springer Netherlands.

Jang, S. J., Tsai, M. F., \& Chen, H. Y. (2013). Development of PCK for novice and experienced university physics instructors: A case study. Teaching in Higher Education, 18(1), 27-39.

Juang, Y. R., Liu, T. C., \& Chan, T. W. (2008). Computer-supported teacher development of pedagogical content knowledge through developing school-based curriculum. Educational Technology \& Society, 11(2), 149-170.

Käpylä, M., Heikkinen, J-P., \& Asunta, T. (2009). Influence of content knowledge on pedagogical content knowledge: the case of teaching photosynthesis and plant growth. International Journal of Science Education, 31(10), 1395-1415.

Karal, I. S., \& Alev, N. (2016). Development of pre-service physics teachers' pedagogical content knowledge (PCK) throughout their initial training. Teacher Development, 20(2), 162-180. doi: 10.1080/13664530.2015.1124138.

Kartal, T., Yamak, H. ve Kavak, N. (2017). Mikro öğretimin fen bilgisi öğretmen adaylarının pedagojik alan bilgileri üzerine etkisi. Kırşehir Ĕgitim Fakültesi Dergisi, 18(3), 740-771.

Kromrey, J. D. \& Renfrow, D. D. (1991, February). Using multiple choice examination items to measure teachers' content-specific pedagogical knowledge. Paper presented at the annual meeting of the Eastern Educational Research Association, Boston.

Kuusisaari, H. (2013). Teachers' collaborative learning-development of teaching in group discussions. Teacher and teaching: Theory and Practice, 19(1), 50-62.

Lankford, D. (2010). Examining the pedagogical content knowledge and practice of experienced secondary biology teachers for teaching diffusion and osmosis. (Unpublished doctoral dissertation). University of Columbia, Missouri.

Leech, N. L., \& Onwuegbuzie, A. J. (2009). A typology of mixed methods research designs. Quality \& Quantity: International Journal of Methodology, 43, 265-275.

Lee, E., \& Luft, J. A. (2008). Experienced secondary science teachers' representation of pedagogical content knowledge. International Journal of Science Education, 30(10), 1343-1363.

Loucks-Horsley, S., Stiles, K. E., Mundry, S., Love, N., \& Hewson, P. W. (2010). Designing professional development for teachers of science and mathematics. (3rd ed.). Thousand Oaks, CA: Corwin Press.

Loughran, J., Berry, A., \& Mullhall, P. (2006). Understanding and developing science teachers' pedagogical content knowledge. Rotterdam: Sense Publishers.

Loughran, J., Mulhall, P., \& Berry, A. (2004). In search of pedagogical content knowledge in science: Developing ways of articulating and documenting professional practice. Journal of Research in Sclence Teaching, 41(4), 370-391.

Luehmann, A. L. (2007). Identity development as a lens to science teacher preparation. Science Education, 91(5), 822-839.

Magnusson, S., Krajcik, J., \& Borko, H. (1999). Nature, sources, and development of pedagogical content knowledge for science teaching. In J. Gess-Newsome \& N. G. Lederman (Eds.), Examining pedagogical content knowledge: The construct and its implications for science education (pp. 95-132). Boston: Kluwer.

Major, T., \& Mulvihill, T. M. (2018). Problem-based learning pedagogies in teacher education: The case of Botswana. Interdisciplinary Journal of Problem-Based Learning, 12(1), 1-11.

Mavhunga, E., \& Rollnick, M. (2016). Teacher or learner-centred? Science teacher beliefs related to topic specific pedagogical content knowledge: A South African case study. Research in Science Education, 46(6), 831-855. doi: 10.1007/s11165-015-9483-9.

McConnell, T. J., Parker, J. M., \& Eberhardt, J. (2013). Assessing teachers' science content knowledge: A strategy for assessing depth of understanding. Journal Science Teacher Education, 24(4), 717-743.

McConnell, T. J., Eberhardt, J., Parker, J., Stanaway, J., Lundeberg, M., Koehler, M. J., et al. (2008). The PBL project for teachers: Using problem based learning to guide k-12 science teachers' professional development. MSTA(Michigan Science Teachers Association) Journal, 53, 16-21. 
McNall Krall, R., Lott, K. H., \& Wymer, C.L. (2009). Inservice elementary and middle school teachers' conceptions of photosynthesis and respiration. Journal Science Teacher, 20, 41-55.

McNaught, C., Lam, P., \& Cheng, K. F. (2012). Investigating relationships between features of learning designs and student learning outcomes. Educational Technology Research and Development, 60(2), 271-286.

Mıhladız, G. (2010). Fen bilgisi öğretmen adaylarının bilimin doğası konusundaki pedagojik alan bilgilerinin araștırılması. (Yayımlanmamış doktora tezi), Gazi Üniversitesi Eğitim Bilimleri Enstitüsü, Ankara.

Mıhladız, G. ve Doğan, A. (2017). Fen bilgisi öğretmen adaylarının bilmin doğası konusundaki pedagojik alan bilgilerinin araştırılması. Hacettepe Üniversitesi Eğitim Fakültesi Dergisi, 32(2), 380-395.

Mihladız, G., \& Timur, B. (2011). Pre-service science teachers views of in-service science teachers'pedagogical content knowledge. Eurasian Journal of Physics and Chemistry Education, Jan (Special Issue), 89-100.

Miles, M. B., \& Huberman, A. M. (1994). Qualitative data analysis (2nd edition). Thousand Oaks, CA: Sage Publications.

Mishra, P., \& Koehler, M. J. (2006). Technological pedagogical content knowledge: A Framework for teacher knowledge. Teachers College Record, 108(6), 1017-1054.

Mthethwa-Kunene, E., Onwu, G. O., \& de Villiers, R. (2015). Exploring biology teachers' pedagogical content knowledge in the teaching of genetics in Swaziland science classrooms. International Journal of Science Education, 37(7), 1140-1165.

Nilsson, P., \& Loughran, J. (2012). Exploring the development of pre-service science elementary teachers' pedagogical content knowledge. Journal Science Teacher Education, 23, 699-721.

Nilsson, P. (2014). "When teaching makes a difference: developing science teachers' pedagogical content knowledge through learning study". International Journal of Science Education, 36(11), 1794-1814. doi:10.1080/09500693.2013.879621.

Nilsson, P., \& Vikström, A. (2015). Making PCK explicit-capturing science teachers' pedagogical content knowledge (PCK) in the science classroom. International Journal of Science Education, 37(17), 28362857.

Onwuegbuzie, A. J., \& Teddlie, C. (2003). A framework for analyzing data in mixed methods research. In A. Tashakkori \& C. Teddlie (Eds.), Handbook of mixed methods in social and behavioral research (pp. 351384). Thousand Oaks, CA: Sage.

Özoğlu, M. (2010). Türkiye'de öğretmen yetiştirme sisteminin sorunları [The problems of teacher training system in Turkey]. Ankara: Siyaset, Ekonomi ve Toplum Araştırmaları Vakfı.

Park, S., Jang, J-Y., Chen, Y-C., \& Jung, J. (2011). Is pedagogical content knowledge (pck) necessary for reformed science teaching? Evidence from an empirical study. Research in Science Education, 41, 245260.

Park, S., \& Oliver, J. S. (2008). Revisiting the conceptualisation of pedagogical content knowledge (pck): PCK as a conceptual tool to understand teachers as professionals. Research Science Education, 38, 261-284.

Park, S., Suh, J., \& Seo, K. (2017). Development and validation of measures of secondary science teachers' pck for teaching photosynthesis. Research in Science Education, 1-25. doi: 10.1007/s11165-016-9578-y.

Pease, M. A., \& Kuhn, D. (2011). Experimental analysis of the effective components of problem-based learning. Science Education, 95, 57-86.

Pepper, C. (2009). Problem based learning in science. Issues in Educational Research, 19(2), 128-141.

Pierrakos, O., Zilberberg, A., \& Anderson, R. (2010). Understanding undergraduate research experiences through the lens of problem-based learning: Implications for curriculum translation. The Interdisciplinary Journal of Problem-Based Learning, 4(2), 35-62.

Pourshafie, T., \& Murray-Harvey, R. (2013). Facilitating problembased learning in teacher education: Getting the challenge right. Journal of Education for Teaching: International Research and Pedagogy, 39(2), 169180 .

Rohaan, E. J., Taconis, R., \& Jochems, W. M. (2009). Measuring teachers' pedagogical content knowledge in primary technology education. Research in Science \& Technological Education, 27(3), 327-338. 
Rollnick, M., Bennett, J., Rhemtula, M., Dharseycand, N., \& Ndlovu, T. (2008). The place of subject matter knowledge in pedagogical content knowledge: A case study of South African teachers teaching the amount of substance and chemical equilibrium. International Journal of Science Education, 30(10), 1365-1387.

Roychoudhry, A., \& Rice, D. (2010). Discourse of making sense of data: implications for elementary teachers' science education. Journal Science Teacher Education, 21, 181-203.

Ruthven, K. (2011). Using international study series and meta-analytic research syntheses to scope pedagogical development aimed at improving student attitude and achievement in school mathematics and science. International Journal of Science and Mathematics Education, 9, 419-458.

Saeli, M., Perrenet, J., \& Jochems, W. M. G. (2012). Bert zwaneveld, programming: teachers and pedagogical content knowledge in the netherlands. Informatics in Education, 11(1), 81-114.

Schneider, R. M., \& Plasman, K. (2011). Science teacher learning progressions: A review of science teachers' pedagogical content knowledge development. Review of Educational Research, 81(4), 530-565.

Schuster, D., Cobern, W. W., Applegate, B., Schwartz, R., Vellom, P., \& Undreiu, A. (2007, October). Assessing pedagogical content knowledge of inquiry science teaching-developing an assessment instrument to support the undergraduate preparation of elementary teachers to teach science as inquiry. Proceedings of the National STEM Conference on Assessment of Student Achievement, hosted by the National Science Foundation and Drury University, Washington, DC.

Seung, E., Park, S., \& Narayan, R. (2011). Exploring elementary pre-service teachers' beliefs about science teaching and learning as revealed in their metaphor writing. Journal Science Education Technology, 20, $703-714$.

Sinelnikov, O. A., Kim, I., Ward, P., Curtner-Smith, M., \& Li, W. (2015). Changing beginning teachers' content knowledge and its effects on student learning. Physical Education and Sport Pedagogy, 21, 425-440. doi: 10.1080/17408989.2015.1043255

Shin, T. S., Koehler, M. J., Lundeberg, M. A., Zhang, M., Eberhardt, J., Zhang, T., et al. (2010). The impact of problem-based learning professional development on science teachers self efficacy and their teaching practices. The Annual Meeting of American Educational Research Association, Denver, CO.

Shulman, L. S. (1986). Those who understand: Knowledge growth in teaching. Educational Researcher, 15(2), 4-14.

Shulman, L. S. (1987). Knowledge and teaching: Foundations of the reform. Harvard Educational Review, 57, $1-22$.

Sungur, S., \& Tekkaya, C. (2006). Effects of problem based learning and traditional instruction on self regulated learning. The Jounal of Educational Research, 99(5), 307-317.

Şenol, Ş. (2012). Araştırma ve örnekleme yöntemleri. (1. Bask1). Ankara: Nobel Yayıncılık.

Taber, K. S. (2014) Understanding and developing science teachers' pedagogic content knowledge. Teacher Development, 18(3), 441-444.

Türk Eğitim Derneği (TED). (2009). Öğretmen Yeterlikleri Özet Rapor. (1.Bask1). ISBN: 978-9944-5128-7-9, Ankara.

Timur, B. (2011). Fen bilgisi ögretmen adaylarının kuvvet ve hareket konusundaki teknolojik pedagojik alan bilgilerinin gelişimi. (Yayımlanmamış doktora tezi). Gazi Üniversitesi Eğitim Bilimleri Enstitüsü, Ankara.

Torp, L., \& Sage, S. (2002). Problems as possibilities: problem based learning for K-16 Education. Alexandria, VA: Association for Supervision and Curriculum Development.

Traianou, A. (2006). Teachers' adequacy of subject knowledge in primary science: assessing constructivist approaches from a sociocultural perspective. International Journal of Science Education, 28(8), 827-842.

Van Driel, J. (2010, February). Model-based development of science teachers' pedagogical content knowledge. Paper presented at the International Seminar 'Professional Reflections', National Science Learning Centre, York.

Veal, W. R., \& MaKinster, J. G. (2001). Pedagogical content knowledge taxonomies. http://wolfweb.unr.edu/homepage/crowther/ejse/vealmak.html adresinden elde edildi.

Weinburgh, M. (2007). The effect of tenebrio obscurus on elementary preservice teachers' content knowledge, attitudes, and self-efficacy. Journal Science Teacher Education, 18, 801-815. 
Weizman, A., Covitt, B. A., Koehler, M. J., Lundeberg, M. A., Oslund, J. A., Low, M. A., Eberhardt, J., \& Urban-Lurain, M. (2008). Measuring teachers'learning from a problem- based learning approach to professional development in science education. Interdisciplinary Journal of Poblem Based Learning, 2, 2960.

Williams, J., Eames, C., Hume, A., \& Lockley, J. (2012). Promoting pedagogical content knowledge development for early career secondary teachers in science and technology using content representations. Research in Science \& Technological Education, 30(3), 327-343.

Yen, H. C., Tuan, H. L., \& Liao, C. H. (2011). Investigating the influence of motivation on students'conceptual learning outcomes in web-based vs. classroom-based science teaching contexts. Research Science Education, 41, 211-224.

Yıldırım, A. ve Şimşek, H. (2011). Sosyal bilimlerde nitel araştırma yöntemleri (8. Baskı). Ankara: Seçkin Yayıncılık.

Yore, L. (2001). What is meant by constructivist science teaching and will the science education community stay the course for meaningful reform? Electronic Journal of Science Education, 5(4), 1-7.

Yurdakul, B. (2010). Yapılandırmacılık. Ö. Demirel (Ed.), Eğitimde yeni yönelimler (s. 39-65). Ankara: Pegem Akademi.

Zhang, M., Lundeberg, M., McConnell, T. J., Koehler, M. J., \& Eberhardt, J. (2010). Using questioning to facilitate discussion of science teaching problems in teacher professional development. Interdisciplinary Journal of Problem Based Learning, 4(1), 57-82.

Zhang, M., Lundeberg, M., \& Eberhardt, J. (2011). Strategic faciliation of problem-based discussion for teacher professional development. Journal of The Learning Science, 20(3), 342-394. 
Ek A

Örnek Problem Senaryoları

\section{Öğrenciyi Anlama Bilgisi Pedagojik Senaryo Örneği}

Yeni öğretim yılında okuldaki diğer fen bilimleri öğretmenleriyle biraraya gelip geçen yılki derslerin bir değerlendirmesini yapmaktasınız. Bu değerlendirmeleri yaparken aynı zamanda bu haftanın öğretim konusu olan dolaşım sistemi ile ilgili geçen dönem aynı konuda öğrencilerden edindiğiniz izlenimler konusunda diğer öğretmenlerle fikir alış verişinde bulunmaktasınız. $\mathrm{Bu}$ konuda, diğer fen bilimleri öğretmenlerinden Semih öğretmen, öğrencilerinden edindiği dönütler doğrultusunda şöyle bir yorum yapmışt: "Öğrencilerin pek çoğu bana söylediler ki; gerçekten bu konuyu öğrenmekte zorlaniyoruz ve birçok bilgiyi birbirine karışıtırlyoruz.Gerçekten ben bu duruma çok hazırlıksız yakalanmıştım. Neden? ögrenemiyorlardı ve ben neleri yanlıs yapıyordum, bunu sorgulamam gerekmekteydi". Semih öğretmenin ifade ettiği bu durumların aynısıyla karşılaşan biri olarak söyledikleri konusunda söze girip şunları ifade ettiğinizi düşünün: dolaşım sistemi konusunu öğretirken adım adım bilgileri sunar ardından öğrencilere sorular yöneltip anlayıp, anlamadıklarını kontrol ederim. İzlediğim bu yolun herzaman etkili bir öğrenme yolu olduğunu düşünürüm. Diğer fen bilimleri öğretmenlerinden Aslı öğretmen söz girerek bana şöyle bir soru yöneltti: Eğer bir konunun öğrenilmesi basit bir dizi adımların takip edilmesiyse, her öğretmen niçin mükemmel bir fen bilimleri öğretmeni olamaz? Bu soru üzerine söze girerek şöyle bir düşünceyi ortaya koydum: "Öğrencilerin ne bidiklerini ve ne öğrendiklerini anlamak için sorular sorarak onların fikirlerinin ne olduğunu bilmek zorundayız”. Aslı öğretmen tekrar devam etti ve ardı ardına şu soruları yöneltti: Onların bu konuyla ilgili başlangıçtaki fikirlerinin ne olduğunu anlamanın en iyi yolu peki nedir? Bu konuya ilişkin olarak öğrencilerin bilgilerini biçimlendiren süreçler nelerdir? Öğrenci fikirlerini bu dersin öğretimi için bir başlama noktası olarak sen nasıl kullanabilirsin? Öğrencilerinin bu konuda edinecekleri kavram yanılgılarının üstesinden gelmelerinde onlara yardım etmek için sağlayacağın deneyimler nelerdir? Öğrencilerin için bu dersin öğrenilmesinde direnç noktaları olarak neyi görmektesin? Ayrıca dersinde ögrencilerinin kavram ve bilgileri etkili birşekilde öğrenmeleri için yapılması gereken öğretim süreçleri nedir?

Yukardaki gibi öğrenci anlayışı üzerine devam eden bir pedagojik tartışmayı düşünün. Yukarıda Aslı öğretmenin ortaya koyduğu soruların cevabını bulduğunuzu ve uyguladığınızı düşünerek, dolaşım sistemi dersinin bitiminde arkadaşlarınızla yendien bir araya geldiğinizi hayal ediniz.

Yukarıdaki soruların cevabı konusunda Aslı öğretmeni ikna etmek için ortaya koyacağın öğrenme ve öğretme oluşumlarını nasıl açıklarsın?

\section{Konu Alan Bilgisi Problem Senaryosu Örneği}

MEB ve Sağlık bakanlığı ortaklaşa fen bilimleri öğretmenleri için "Sağlıklı Beslenme ve Sağlıklı Bireyler" konulu bir poster yarışması düzenlenmektedir. Bu yarışmadaki öncelikli amaç öğretmenleri sağlıklı beslenme konusunda bilinçlendirmek ve bu bilgilerinin öğrencilere ulaştırılmasını sağlamaktır. Yarışmanın birincisi 10.000 TL ödülünde sahibi olacaktır. Bu etkinliğe katılacak öğretmenlerin, yarışmayı kazanmaları için değerlendirme jürisindeki kişileri, aşağıdaki verilmiş problemlerin çözümüne ilişkin olarak ikna edebilmeleri gerekmektedir. Bu amaçla öğretmenlere beş başlık altında yarışma konuları sunulmuştur. Bu yarışma konuları şu şekildedir;

1. Yarışma konusu: Bireylerde besinlerin sindiriminde midede bulunan hücrelerin etki mekanizmasına; $\mathrm{pH}$ 'ın ve enzimlerin etkisi var midır?

2. Yarışma konusu: Besinlerin sindirimi sonucu oluşan ürünlerden faydalanılmasında emilim mekanizmasının işleyişi gerekli midir?

3. Yarışma konusu: Stres, enfeksiyon ve çevresel faktörlerin sindirimsel fonksiyon üzerinde etkisi var mıdır?

4. Yarışma konusu: Toksik mikroorganizmalar sindirim sistemi üzerinde nasıl komplikasyonlara neden?

5. Yarışma konusu: Akdeniz ülkelerindeki yaşayan bireylerde, Avrupa ülkelerinde yaşayan bireylere göre daha düşük koroner damar hastalıklarının görülebilme nedenleri?

Yarışmaya katılan bir fen bilimleri öğretmeni olarak birinciliği almak için her bir soruya ilişkin çözümlemelerin neler olurdu? 